\title{
Assessment of the impacts of oil: opportunities and challenges for economic development in Sudan
}

Citation for published version (APA):

Nour, S. (2011). Assessment of the impacts of oil: opportunities and challenges for economic development in Sudan. UNU-MERIT, Maastricht Economic and Social Research and Training Centre on Innovation and Technology. UNU-MERIT Working Papers No. 006 https://doi.org/10.2139/SSRN.1949169

Document status and date:

Published: 01/01/2011

DOI:

10.2139/SSRN.1949169

Document Version:

Publisher's PDF, also known as Version of record

\section{Please check the document version of this publication:}

- A submitted manuscript is the version of the article upon submission and before peer-review. There can be important differences between the submitted version and the official published version of record.

People interested in the research are advised to contact the author for the final version of the publication, or visit the DOI to the publisher's website.

- The final author version and the galley proof are versions of the publication after peer review.

- The final published version features the final layout of the paper including the volume, issue and page numbers.

Link to publication

\footnotetext{
General rights rights.

- You may freely distribute the URL identifying the publication in the public portal. please follow below link for the End User Agreement:

www.umlib.nl/taverne-license

Take down policy

If you believe that this document breaches copyright please contact us at:

repository@maastrichtuniversity.nl

providing details and we will investigate your claim.
}

Copyright and moral rights for the publications made accessible in the public portal are retained by the authors and/or other copyright owners and it is a condition of accessing publications that users recognise and abide by the legal requirements associated with these

- Users may download and print one copy of any publication from the public portal for the purpose of private study or research.

- You may not further distribute the material or use it for any profit-making activity or commercial gain

If the publication is distributed under the terms of Article $25 \mathrm{fa}$ of the Dutch Copyright Act, indicated by the "Taverne" license above, 


\section{UNITED NATIONS \\ UNIVERSITY}

UNU-MERIT

\section{Working Paper Series}

\section{\#2011-006}

Assessment of the Impacts of Oil: Opportunities and Challenges for Economic Development in Sudan

By Samia Satti Osman Mohamed Nour 


\section{UNU-MERIT Working Papers}

ISSN 1871-9872

Maastricht Economic and social Research and training centre on Innovation and Technology, UNU-MERIT

UNU-MERIT Working Papers intend to disseminate preliminary results of research carried out at the Centre to stimulate discussion on the issues raised. 


\title{
Assessment of the Impacts of Oil: Opportunities and Challenges for Economic Development in Sudan
}

\author{
By Dr. Samia Satti Osman Mohamed Nour ${ }^{1}$
}

(January 2011)

\begin{abstract}
This paper provides an assessment of the impacts of oil and discusses the opportunities and challenges for enhancing economic development in Sudan. One advantage of our analysis in this paper is that we provide a more comprehensive analysis using the most recent secondary data to discuss the positive and negative impacts of oil for enhancing economic development in Sudan. We explain that the various positive impacts of oil and the opportunities for enhancing development in Sudan economy include the impacts of oil in satisfying domestic consumption and achievement of self sufficiency, increasing government and public revenues, rapid and impressive economic growth as measured by the growth in the GDP and its composition and structure, increasing foreign direct investment (FDI) and increasing the volume of foreign trade as measured by the volume and structure of exports. We find that while oil has recently contributed to the improvement of economic performance in the country, the recent heavy dependence on it, may lead to negative impacts and serious challenges for the Sudan since oil is an exhaustible resource and because of the instability of oil prices in the international market the revenue from oil is uncertain and volatile and may lead to instability of economic growth. Moreover, the increasing dependence on oil leads to increasing debate for and against the incidence of the Dutch Disease in Sudan economy, the lack of diversification and the challenges related to potential north-south conflict and division of the country.
\end{abstract}

Keywords: Oil economy, oil impacts, economic development, Sudan JEL classification: O10, O11, Q30, Q32, Q40, Q43

\footnotetext{
${ }^{1}$ Corresponding Author: Dr. Samia Satti Osman Mohamed Nour, Visiting Research Fellow - University of Maastricht, School of Business and Economics, UNU-MERIT, Maastricht, the Netherlands; and Assistant Professor of Economics, Economics Department, Faculty of Economic and Social Studies, Khartoum University, Khartoum, Sudan. E-mail: samiasatti@yahoo.com; samia_satti@hotmail.com. The first draft of this paper was originally prepared within the author's research project "Technological Change and Skill Development: the case of Sudan" during the author's time as a visiting research fellow at the University of Maastricht, School of Business and Economics, UNU-MERIT, Maastricht, the Netherlands. The author gratefully acknowledges the Arab Fund for Economic and Social Development, Kuwait, for research grant and fellowship and University of Maastricht, School of Business and Economics, UNU-MERIT for the good hospitality during her visiting research fellowship. The author would like to gratefully thank Prof. Joan Muysken and Dr. Hisham Mohamed Hassan for their useful comments on the first draft of this paper. All the usual disclaimers apply.
} 


\section{Introduction}

This paper investigates the impacts of oil in enhancing economic development in the Sudan. Notably; the aim of this paper is twofold: first to explain some stylized facts to examine the positive impacts and opportunities that oil offer to enhance economic development in the Sudan and second to explain some stylized facts to examine the other negative impacts and challenges that oil created for economic development in the Sudan.

Explaining the case of Sudan is both interesting and significant because of the recent increasing fast growth and structural change in Sudan economy after the exploitation of oil in the country. The importance of the country increased after the recent exploitation of oil, which has strategic importance in the global economy. According to the World Bank (2008) Sudan is one of the newest significant oil producing countries in the World; Sudan is the third largest oil producers in Sub Saharan Africa (SSA) behind Nigeria and Angola. As a result of oil exploitation, in recent years, the structure of the Sudanese economy has shifted over time, from predominantly reliant on agriculture for growth and exports, to its current reliance on the oil sector (WB, 2008). In recent years the increasing dependence on oil leads to sound economic growth. Consequently, Sudan's real economic growth averaged about 9\% during (2005-2006), putting Sudan among the fastest growing economies in Africa (WB, 2008). But while oil has recently contributed to the improvement of economic performance in the country, the recent heavy dependence on it, may lead to serious challenges for the Sudan since oil is an exhaustible resource and, because of the instability of oil prices, the revenue from oil is uncertain and volatile. Moreover, the increasing dependence on oil leads to increasing debate for and against the incidence of the Dutch Disease in Sudan economy. ${ }^{2}$

Moreover, the analysis of the impacts of oil is interesting because both the growing inflow of FDI and the increased wealth from oil has encouraged migration to the Sudan. Consequently, migrant workers have increased in the labour market, particularly in the private sector that most probably affected the structure of labour market and contributed to the growing unemployment rate in Sudan. In addition, explaining the impacts of oil is important because Sudan suffered from structural problem related to the lack of political stability, continuous conflict; regional disparities due to imbalanced development strategies; high poverty rate; high unemployment rate; low skill level and low human development indicators.

The rest of this paper is organized in the following way. Section 2 explains the general socioeconomic characteristics of Sudan, Section 3 examines the impacts of oil in enhancing economic development in Sudan, Section 4 concludes.

\footnotetext{
2 "The Dutch Disease is a process in which the discovery of natural resources causes a country to experience a 'change in the group of reference' from one that aim at generating a trade surplus in manufacturing to one that able to generate a trade surplus in primary commodities. The country experiencing this disease also shows differences between employment in manufacturing. The
} 


\section{Economic characteristics and strategic problems for development in the Sudan}

Before assessing the impacts of oil in enhancing economic development in the Sudan it is useful to start by explaining the general political context and socio-economic characteristics of the Sudan. Next, we examine the impact of oil in Sudan economy in the next section, and we attempt to link these to general socio-economic characteristics of Sudan.

\section{1. Geo-political setting, political context and north-south conflict in the Sudan}

Starting with the geographical location and features, geographically, Sudan is situated in northern (or northeastern) Africa, it is the largest country on the Africa continent and the Arab region and the tenth largest in the world in terms of area covering 2492360 square kilometers or about (967500 square miles) i.e. nearly one - tenth of the total area of Africa. Sudan has lengthy borders with nine countries and for its strategic location; Sudan seems as a bridge between Arab and Africa regions. ${ }^{3}$ The principal physical feature of the Sudan is the river Nile and its tributaries. The world's longest river, the Nile, divides Sudan between east and west sides. The Nile system run through approximately 2.5 thousand miles from south to north, the Blue Nile River joins the White Nile River at Khartoum to form the river Nile. The Nile flood provides Sudan with vast alluvial agricultural lands and the most fertile region between the White Nile River and Blue Nile River. The climate of Sudan ranges from the equatorial in the extreme south to an arid desert in the north. ${ }^{4}$

As for the political context since independence in 1956 and over the past five decades Sudan was ruled by three civilian governments (1956-1958, 1964-1969 and 1985-1989) and three Military governments (1958-1964, 1969-1985, 1989-2005). Sudan suffered from political instability, as the short-lived three civilian governments were often removed and overthrown by military governments. For instance, the first civilian government after independence (1956-1958) was overthrown in 1958 by the Abbud Military Government (1958-1964), the second elected civilian government (1964-1969) was overthrown in 1969 and by the Nimeiri Military Government (1969-1985) and once again the third elected civilian government (1985-1989) was overthrown in 1989 by Al Bashir Military Government (19892005). Since the signing and implementation of the Comprehensive Peace Agreement (CPA) in January 2005 the Sudan is ruled by the Government of National Unity (GNU) which represents a power-sharing government between the National Congress Party (NCP) of the north and Sudan People's Liberation Movement (SPLM) of the south. As for government and politics, the politics of Sudan takes place, in the framework of a federal presidential

process of de-industrialisation due to the discovery of natural resources, mainly natural gas apparent from the case of Holland”. (cf. Palma, 2003: 21)

${ }^{3}$ Sudan has lengthy borders with nine countries, namely: it is bordered by Egypt to the north, Libya to the northwest, Eritrea and Ethiopia to the east, Kenya and Uganda to the south, Democratic Republic of Congo and Central African Republic to the southwest and Chad to the west, the Red Sea to the northeast separates Sudan from the Kingdom of Saudi Arabia

${ }^{4}$ See Sudan Central Bureau of Statistics Statistical Year Book (2008), “General Information” pp. XI-XII. 
representative democratic republic, the judiciary is independent and obtained by the Constitutional Court and the legislative power is vested in both the government and in the two chambers, the National Assembly (lower) and the Council of States (upper), the bicameral National Legislature is the official Sudanese parliament consists of 500 appointed members. ${ }^{5}$

The record of the political context in Sudan is characterized by a long history of serious political instability, continuing civil wars and complex conflict between the north and the south that first occurred even before Sudan gained its independence and continued after gaining its independence in 1956. For instance, over the period (1955-2005), Sudan has suffered from instability and two civil wars between the north and the south. Sudan finally ended the second civil war by signing the Comprehensive Peace Agreement (CPA) ${ }^{6}$ and by adopting a new constitution in 2005. ${ }^{7}$ The implementation of the CPA implies several important agreed issues, which included the formation of the Government of National Unity (GNU) in 2005, which represents a power-sharing government between the National Congress Party (NCP) of the north and Sudan People's Liberation Movement (SPLM) of the south. Moreover, the implementation of the CPA implies several other important agreed issues, which included the establishment of an interim transitional period of autonomous rule for the South for six years (2005-2011) and it followed by the self-determination for the southern Sudan and a referendum in Southern Sudan to decide on unity or secession from the north (that was just held in January 2011). Now near the end of the Interim Period, both the north and south have seen significant benefits from the peace though significant political economy risks remain. While national income has increased dramatically, the post-conflict environment continues to be characterized by difficult political and security situations and internal and external tensions. Internally, the relations between north and south remain tense, the performance of Government of National Unity (GoNU) has often constrained by and suffered from the inconsistency and disagreement due to the continuous dispute and conflict between the ruling NCP and the SPLM. Externally, Sudan remains at the center of intense international pressure over the civilian impact of continued conflict in the Darfur region of the country, which is so far unresolved. These issues are reminders that the political economy context in Sudan will remain complex and uncertain, even for a post-conflict country. ${ }^{8}$ So far Sudan is still suffering from political instability due to escalation and continuation of conflict in the country. In our view this political instability may lead to serious implications in the short and long run economic growth and development in Sudan. Moreover, the unbalanced

\footnotetext{
${ }^{5}$ Sudan is divided into twenty-six states which in turn are subdivided into 87 districts; the ten states in Southern Sudan are subdivided into 84 counties. The states are: Al Jazirah, Al Qadarif, Blue Nile, Central Equatoria, East Equatoria, Jonglei, Kassala, Khartoum, Lakes, North Bahr al Ghazal, North Darfur, North Kurdufan, Northern, Red Sea, River Nile, Sennar, South Darfur, South Kurdufan, Unity, Upper Nile, Warab, West Bahr al Ghazal, West Darfur, West Equatoria and White Nile.

${ }^{6}$ The CPA was signed on January 9, 2005, ending conflict between the Government of Sudan and the Sudan People's Liberation Movement/Sudan People’s Liberation (SPLM) Army.

${ }^{7}$ See: http://en.wikipedia.org/wiki/Sudan: Accessed in June 01 ${ }^{\text {st }}, 2010$.

${ }^{8}$ See WB-DTIS, (2008): p.1.
} 
development in Sudan, with a large regional disparity remains a potential source for conflict and political instability. Furthermore, from institutional perspective, Sudan suffered from the lack of sound and systematic institutional setting and the lack of commitment to implementation of long run sustainable and balanced economic and development plans and strategies. In our view the interaction between these important endogenous political, economic and institutional factors most probably have not only been important for the interpretation of the root causes of the north-south conflict but most probably also important for the interpretation of the root causes of continued low standard of economic development in Sudan for a long time period. This implies that the interaction between these political, economic and institutional factors together have unfortunately continued to contribute to a low standard of economic development in Sudan as we explain below in the next section.

\section{2. General socio-economic characteristics of Sudan}

As for the general socio-economic characteristics of the Sudan, Table 1 below explains the demographic structure and the major socio-economic characteristics for Sudan. Table 1 below shows the considerable diversity between Sudan, African and Arab countries and the world regions in terms of population, standard of economic development as measured by GDP per capita and human development index. Sudan generally has higher population number coupled with lower standard of economic development. The World Bank classification of economies puts Sudan among the lower medium-income economies. Moreover, the UNDP HDI shows that the average GDP per capita for Sudan falls within the world medium-income bracket and is, on average, lower than for those of the world and Arab countries. This also holds for other HDI components: average life expectancy, literacy rate and combined enrolment ratios.

\begin{tabular}{|c|c|c|c|c|c|c|}
\hline+2 & $\begin{array}{l}\text { Population }^{a b} \text { (millions) } \\
(2007-2008)\end{array}$ & $\begin{array}{l}\text { GDP per capita } \\
\left(\text { PPP }^{c} \text { US\$) }\right.\end{array}$ & $\begin{array}{l}\text { Human } \\
\text { Development } \\
\text { Index }{ }^{a}(\%)\end{array}$ & $\begin{array}{l}\begin{array}{l}\text { Life } \\
\text { Expectancy } \\
\text { (years) }\end{array} \\
\text { (yen }\end{array}$ & $\begin{array}{l}\begin{array}{l}\text { Adult } \\
\text { Rate }^{a} \text { (iteracy } \\
\text { (\% aged } \\
15 \text { and above) }\end{array} \\
\end{array}$ & $\begin{array}{l}\text { Combined } \\
\text { enrolment } \\
\text { ratio }^{a}(\%) \\
\end{array}$ \\
\hline & 2007 & 2007 & 2007 & 2007 & 1999-2007 & 2007 \\
\hline Sudan $^{b}$ & 39.2 & 2086 & 0.531 & 57.9 & 60.9 & 39.9 \\
\hline Africa & 638.6 & 2,729 & 0.547 & 53.9 & 63.3 & 55.9 \\
\hline Asia & 3178.8 & 5,837 & 0.724 & 68.8 & 82.1 & 64.5 \\
\hline Europe & 720.8 & 24,775 & 0.902 & 74.9 & 99.2 & 88.2 \\
\hline Latin America and the Caribbean & 437.5 & 10,077 & 0.821 & 73.4 & 91.2 & 83.4 \\
\hline Northern America & 282.7 & .. & 0.952 & 79.2 & 96.5 &.. \\
\hline Oceania & 26.9 &.. & 0.900 & 76.4 & 93.0 &.. \\
\hline Arab States & 229.3 & 8,202 & 0.719 & 68.5 & 71.2 & 66.2 \\
\hline GCC & 23.1 & 30,415 & 0.868 & 74.0 & 86.8 & 77.0 \\
\hline Central and Eastern Europe and the CIS & 468.1 & 12,185 & 0.821 & 69.7 & 97.6 & 79.5 \\
\hline CIS & 280.9 & 10,487 & 0.802 & 67.0 & 99.4 & 81.1 \\
\hline East Asia and the Pacific & 1658.5 & 5,733 & 0.770 & 72.2 & 92.7 & 69.3 \\
\hline Latin America and the Caribbean & 437.5 & 10,077 & 0.821 & 73.4 & 91.2 & 83.4 \\
\hline South Asia & 1200.0 & 2,905 & 0.612 & 64.1 & 64.2 & 58.0 \\
\hline Sub-Saharan Africa & 483.1 & 2,031 & 0.514 & 51.5 & 62.9 & 53.5 \\
\hline OECD & 1048.6 & 32,647 & 0.932 & 79.0 &.. & 89.1 \\
\hline European Union (EU27) & 471.6 & 29956 & 0.937 & 79 & .. & 91 \\
\hline High human development & 784.2 & 12,569 & 0.833 & 72.4 & 94.1 & 82.4 \\
\hline Medium human development & 3388.5 & 3,963 & 0.686 & 66.9 & 80.0 & 63.3 \\
\hline Low human development & 240.2 & 862 & 0.423 & 51.0 & 47.7 & 47.6 \\
\hline World & 5290.5 & 9,972 & 0.753 & 67.5 & 83.9 & 67.5 \\
\hline
\end{tabular}

Source: UNDP (2009). Notes: ${ }^{\mathrm{a}} 2007,{ }^{\mathrm{b}} 2008,{ }^{\mathrm{c}} \mathrm{PPP}$ - purchasing power parity.

\footnotetext{
${ }^{9}$ The World Bank and United Nations Development Programme (UNDP) Human Development Report classify world countries differently according to income level. We use the World Bank classification of economies that puts Sudan in the lower middleincome category or group.
} 
Moreover, according to UNDP indicators and estimates from International Monetary Fund's World Economic Outlook (IMF 2002), as in most other typically poor developing countries Sudan continued to suffer from widespread and high rates of poverty and unemployment.

In addition, one stylised fact on the case of Sudan is that Sudan is large by regional standards, but its economy is small in global terms. According to the World Bank and United Nations classification and definition, Sudan is classified among Sub-Saharan African countries and among the poor and low income and highly indebted countries. For instance, the UNDP and the World Bank shows the low GDP per capita income in Sudan which is in excess of only least developing countries, but less than all other World regions. Despite the high and increasing inflow of Foreign Direct Investment (FDI) to Sudan, but different from other World regions, Sudan suffered from the high increase in debt services both as percentage of GDP and as percentage of exports over the period (1990-2005). That was most probably because like most African countries, Sudan's economy has relied heavily on a large influx of foreign aid from different sources; Sudan is among the top ten recipients of gross Official Development Assistance during (1990-2007)- see Table 2 below

\begin{tabular}{|c|c|c|c|c|c|c|c|c|c|c|c|c|c|}
\hline \multirow[t]{3}{*}{ Country and Regions } & \multirow{3}{*}{$\begin{array}{l}\text { GDP } \\
\text { Per } \\
\text { capita }\end{array}$} & \multicolumn{4}{|c|}{$\begin{array}{l}\text { Official development assistance } \\
\text { (ODA) received (net disbursements) }\end{array}$} & \multirow{2}{*}{\multicolumn{2}{|c|}{$\begin{array}{l}\text { FDI } \\
\% \text { GDP }\end{array}$}} & \multirow{2}{*}{\multicolumn{2}{|c|}{$\begin{array}{l}\text { Private Capital } \\
\text { \%GDP }\end{array}$}} & \multicolumn{4}{|c|}{ Debt services } \\
\hline & & \multirow{2}{*}{$\begin{array}{l}\text { Total } \\
\text { (US\$ } \\
\text { million) } \\
2005\end{array}$} & \multirow{2}{*}{$\begin{array}{l}\begin{array}{l}\text { Per } \\
\text { capita } \\
\text { (US\$) }\end{array} \\
2005\end{array}$} & \multicolumn{2}{|c|}{ As \% of GDP } & & & & & \multicolumn{2}{|c|}{$\%$ GDP } & \multicolumn{2}{|c|}{ \% Exports } \\
\hline & & & & 1990 & 2005 & 1990 & 2005 & 1990 & 2005 & 1990 & 2005 & 1990 & 2005 \\
\hline Sudan & 2,083 & $1,828.6$ & 50.5 & 6.2 & 6.6 & -0.2 & 8.4 & 0.0 & 0.2 & 0.4 & 1.4 & 8.7 & 6.5 \\
\hline Developing countries & 5,282 & $86,043.0$ & 16.5 & 1.4 & 0.9 & 0.9 & 2.7 & 0.5 & 1.5 & 4.4 & 4.6 & 15.6 & 13.0 \\
\hline LDCs & 1,499 & $25,979.5$ & 33.9 & 11.8 & 9.3 & 0.3 & 2.6 & 0.5 & 0.8 & 3.0 & 2.3 & 16.9 & 7.0 \\
\hline Arab countries & 6,716 & $29,612.0$ & 94.3 & 2.9 & 3.0 & 0.5 & 1.5 & n.a. & 1.8 & n.a. & n.a. & 21.3 & 8.5 \\
\hline Asia and the Pacific & 6,604 & $9,541.6$ & 4.9 & 0.8 & 0.2 & 1.7 & 3.4 & n.a. & n.a. & n.a. & n.a. & 9.9 & 2.6 \\
\hline Latin America and the Caribbean & 8,417 & $6,249.5$ & 11.3 & 0.5 & 0.3 & 0.8 & 2.9 & 0.5 & 1.2 & 4.0 & 6.6 & 23.7 & 22.7 \\
\hline South Asia & 3,416 & $9,937.5$ & 6.3 & 1.2 & 0.8 & n.a. & 0.8 & 0.3 & 1.2 & 2.3 & 2.6 & 22.8 & 15.4 \\
\hline Sub-Saharan Africa & 1,998 & $30,167.7$ & 41.7 & 5.7 & 5.1 & 0.4 & 2.4 & 0.3 & 1.7 & n.a. & n.a. & 10.5 & 5.8 \\
\hline Central and Eastern Europe & 9,527 & $5,299.4$ & 13.1 & n.a. & 0.3 & n.a. & 4.0 & n.a. & 4.4 & n.a. & n.a. & n.a. & n.a. \\
\hline OECD & 29,197 & 759.4 & n.a. & n.a. & n.a. & 1.0 & 1.6 & n.a. & n.a. & n.a. & n.a. & n.a. & n.a. \\
\hline High Income countries & 33,082 & n.a. & n.a. & n.a. & n.a. & 1.0 & 1.6 & n.a. & n.a. & n.a. & n.a. & n.a. & n.a. \\
\hline Middle Income countries & 7,416 & $42,242.2$ & 13.7 & 0.7 & 1.3 & 0.9 & 3.1 & 0.4 & 2.2 & 4.5 & 5.5 & 20.3 & 14.3 \\
\hline Low Income countries & 2,531 & $44,123.0$ & 18.2 & 4.1 & 3.2 & 0.4 & 1.4 & 0.3 & 1.0 & 3.7 & 3.1 & 27.1 & 13.7 \\
\hline World & 9,543 & $106,372.9$ & 16.3 & 0.3 & 0.2 & 1.0 & 1.9 & n.a. & 2.0 & n.a. & 5.1 & n.a. & n.a. \\
\hline
\end{tabular}

As for the structure of the economy, since long, the structure of Sudan economy is characterised by small share of industry, notably, manufacturing; high share of agriculture and services sectors in GDP and employment and dependence on primary exports, mainly, dependence on the exports of agricultural products- see Table 3 below. Agricultural sector remains Sudan's most important sector, employing $80 \%$ of the workforce and contributing 39\% of GDP. According to World Development Indicator database (WDI 2005) the structure of Sudan economy shows the importance of both the agricultural (71\%, 39\%) and services sectors $(21 \%, 43 \%)$ compared to the industrial sector $(9 \%, 18 \%)$ in terms of both the share in total employment (1990) and value added as a percentage of GDP (2002) respectively. ${ }^{10}$ The share of agriculture in GDP increased from 30.3\% in 1990 to $49.8 \%$ in 1999 and then declined to 31.1\% in 2009; the share of the services in GDP declined from 54.4\% in 1990 to 
34.4\% in 1999 and then increased to $45.0 \%$ in 2009; the share of industry in GDP increased from $15.4 \%$ in 1990 to $15.8 \%$ in 1999 and then increased to $23.9 \%$ in 2009- see Table 3.

In 1999, Sudan began exporting crude oil and in the last quarter of 1999, recorded its first trade surplus. Increased oil production revived light industry, and expanded export processing zones helped sustain GDP growth at $6.1 \%$ in 2003. These gains, along with improvements to monetary policy, have stabilized the exchange rate. In recent years after the exploitation of oil Sudan economy become increasingly dependent on oil exports, and the economy turned into an oil dependent economy. Currently oil is Sudan's main export, and the production is increasing dramatically. With rising oil revenues the Sudanese economy is booming, with a growth rate of about $9 \%$ in 2007. Sudan's non-oil exports are diversified across a wide range of products, but most of these exports are concentrated in few countries (WB-DTIS, 2008). Sudan's real growth of trade of 25\% in 2007 represents the second highest growth in the world for that year among all countries (WB-DTIS, 2008). In recent years the increasing dependence on oil leads to sound economic growth. Consequently, Sudan's real economic growth averaged about 9\% during (2005-2006), putting Sudan among the fastest growing economies in Africa (WB, 2008). According to the World Bank (2008) Sudan is one of the newest significant oil producing countries in the World; Sudan is the third largest oil producers in Sub Saharan Africa (SSA) behind Nigeria and Angola. As a result, in recent years, the structure of the Sudanese economy has shifted over time, from predominantly reliant on agriculture for growth and exports, to its current reliance on the oil sector (WB, 2008). But while the increasing dependence on oil leads to several positive impacts it also lead to several negative impacts and increasing debate for and against the incidence of the Dutch Disease in Sudan economy as we will explain below in the next sections.

Table (3)- The Performance, Structure and Structural Change in Sudan Economy (1990-2009)

\begin{tabular}{|c|c|c|c|c|c|c|c|c|c|c|c|c|c|}
\hline \multirow[t]{2}{*}{ Year } & \multirow[t]{2}{*}{ GDP } & \multirow[t]{2}{*}{$\begin{array}{l}\text { GDP } \\
\text { Growth } \\
\text { Rate } \\
\end{array}$} & \multirow[t]{2}{*}{$\begin{array}{l}\text { GDP Per } \\
\text { capita }\end{array}$} & \multirow[t]{2}{*}{$\begin{array}{ll}\text { GDP Per } \\
\text { capita Growth } \\
\text { Rate }\end{array}$} & \multirow[t]{2}{*}{$\begin{array}{l}\text { Inflati } \\
\text { on } \\
\text { Rate } \\
\end{array}$} & \multirow[t]{2}{*}{$\begin{array}{l}\text { Exchange } \\
\text { Rate }\end{array}$} & \multirow[t]{2}{*}{$\begin{array}{l}\text { Balance of } \\
\text { payment }\end{array}$} & \multicolumn{3}{|c|}{ Balance of Trade } & \multicolumn{3}{|c|}{$\begin{array}{l}\text { Structure of Sudan Economy (share o } \\
\text { sectors in GDP) }\end{array}$} \\
\hline & & & & & & & & Exports & Imports & Balance & Agriculture & Industry & Services \\
\hline 1990 & 244.7 & 5.4 & 47.7 & 0 & 41 & 0.45 & $\begin{array}{l}-76.1 \\
\end{array}$ & 374 & 618.4 & -244.4 & 30.3 & 15.4 & 54.4 \\
\hline 1991 & 276.8 & 7.5 & 81 & 69.8 & 62.7 & 0.69 & -101.3 & 308.7 & 890.3 & -581.6 & 28.7 & 17.6 & 53.9 \\
\hline 1992 & 4327.8 & 6.5 & 17.2 & -78.7 & 105.4 & 9.7 & -58.1 & 319.3 & 820.9 & -501.6 & 33.7 & 17.1 & 49.1 \\
\hline 1993 & 5862.1 & 4.5 & 37.6 & 118.4 & 115 & 16.1 & 37.7 & 417.3 & 944.9 & -527.6 & 37.9 & 17.4 & 44.5 \\
\hline 1994 & 6351.2 & 1 & 72.5 & 92.7 & 96.3 & 29.6 & 17.9 & 535.6 & 1059.6 & -524 & 40.1 & 16.4 & 43.5 \\
\hline 1995 & 9880.7 & 5.9 & 151.7 & 109.4 & 177.2 & 55.9 & -58.1 & 555.7 & 1184.8 & -629.1 & 43.1 & 15.8 & 41.1 \\
\hline 1996 & 8259.3 & 5.9 & 375.9 & 147.7 & 76.3 & 125 & -63.9 & 620.3 & 1504.5 & -884.2 & 44.9 & 14.5 & 40.6 \\
\hline 1997 & 10684.8 & 6.3 & 563.7 & 50 & 52.6 & 156.9 & -36.2 & 594.2 & 1421.9 & -827.7 & 47.6 & 15.1 & 37.2 \\
\hline 1998 & 11513.7 & 6.4 & 743.7 & 31.9 & 28.2 & 198.8 & 25.1 & 595.7 & 1732.2 & -1136.5 & 48.6 & 15 & 36.2 \\
\hline 1999 & 10325 & 6.7 & 892.3 & 20 & 6.4 & 252 & 111.5 & 780.1 & 1256.2 & -476.1 & 49.8 & 15.8 & 34.4 \\
\hline 2000 & 11242.2 & 8 & $1,083.10$ & 21.4 & 8.5 & 257.2 & 81.5 & 1807 & 1553 & 254 & 46.4 & 21.4 & 32.2 \\
\hline 2001 & 12596.5 & 6.7 & $1,274.00$ & 17.6 & 4.8 & 257.3 & -90.04 & 1547 & 1457 & 90 & 45.6 & 22.8 & 31.6 \\
\hline 2002 & 3924 & 6.5 & $1,457.40$ & 14.4 & 8.3 & 236 & 198.72 & 1949 & 2179.22 & -230.11 & 46 & 23.2 & 30.9 \\
\hline 2003 & 4549 & 6 & $1,656.40$ & 13.7 & 7.7 & 261 & 422.6 & 2542.2 & 2536.1 & 6.07 & 44 & 24.1 & 30.3 \\
\hline 2004 & 5278 & 7.2 & $1,991.20$ & 20.2 & 8.5 & 258 & 730.2 & 3777.75 & 3586.18 & 191.57 & 40 & 28.0 & 32.0 \\
\hline 2005 & 6283 & 8 & $2,421.20$ & 21.6 & 8.5 & 245.6 & 530.5 & 4824.3 & $5,946.0$ & -1121.7 & 39.0 & 28.0 & 32.0 \\
\hline 2006 & $22,217.0$ & 10.0 & $2,719.00$ & 12.3 & 7.2 & 2.0248 & -208.6 & $5,656.6$ & $7,104.0$ & $-1,448.1$ & 36.8 & 27.5 & 35.7 \\
\hline 2007 & 22,21 & 10.5 & $3,059.20$ & 12.5 & 8.1 & 2.0308 & -282 & $8,879.2$ & $7,722.4$ & $\begin{array}{l}1,156.8 \\
\end{array}$ & 35.3 & 30.6 & 34.1 \\
\hline 2008 & 26.03 & 7,8 & $3,262.60$ & 6.6 & 14,3 & 2,09 & 21.1 & $11,670.5$ & $8,229.4$ & $3,441.1$ & 29.3 & 29.2 & 41.5 \\
\hline 2009 & 27.63 & 6.1 & & & 11,2 & 2,32 & -502.2 & $7,833.7$ & $8,528.0$ & -694.3 & 31.1 & 23.9 & 45.0 \\
\hline
\end{tabular}

${ }^{10}$ See for instance, the World Development Indicator database: WDI (2005). 


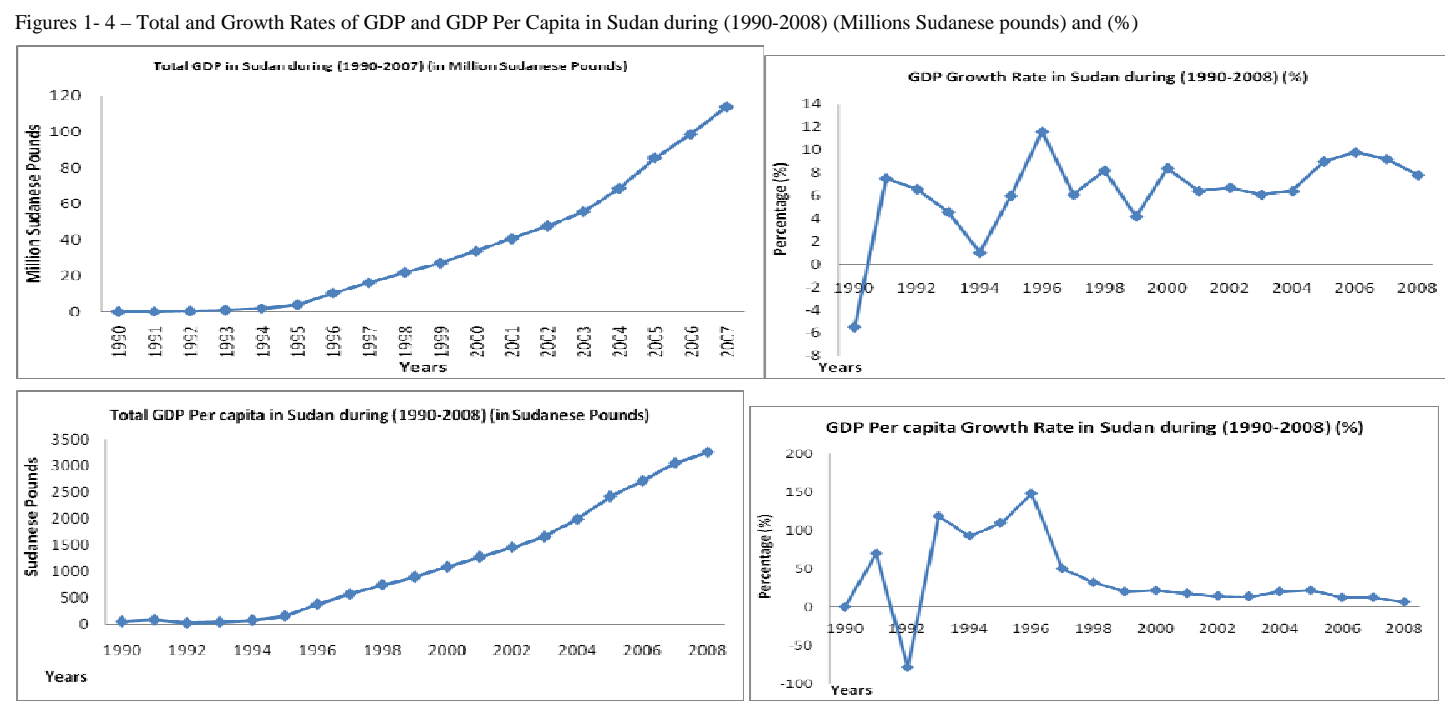

Source: Adapted from Sudan Central Bureau of Statistics: Sudan Ministry of the Cabinet- central bureau of statistics: Sudan statistical year book: Sudan statistics 1990 2008: pp. 39-43

As for the economic reform, since gaining its independence in 1956 and over the past decades, Sudan economy suffered from continuing macroeconomic instability and crisis, low GDP per capita income, presence of high rates of poverty, unemployment, inequalities, weak economic performance and an uneven growth until recent years. The imperative of reforming macroeconomic management in Sudan dates back to the 1970s and 1980s, when the first wave of reforms was undertaken during 1978-1984. A new wave of intensive reforms was initiated, culminating in the adjustment policies of the medium-term National Economic Salvation Programme (NESP) for 1990/91-1992/93, which was merged into the Comprehensive National Plan (CNP) of 1992-2002. The broad objective of NESP was the revitalization of the Sudanese economy. The government reform efforts emphasized four aspects in particular ${ }^{11}$ : (a) restoring macroeconomic stability and combating runaway inflation through tough fiscal and monetary policies; stabilization of the foreign exchange rate through managed floating; (b) emphasizing market-oriented economic activity, liberalization, abolition of controls and deregulation of imports, foreign exchange, and prices; (c) limiting the role of the state through privatizing public-sector enterprises and extending the role of the private sector to all activities including health, education and utilities; and (d) Encouraging saving by reforming the financial system and banking sector and introducing new saving instruments. ${ }^{12}$ Since the late 1990s, notably, 1997, due to implementation of macroeconomic reforms policies recommended by the IMF, Sudan then finally achieved great improvement in the performance of most macroeconomic indicators, impressive real economic growth and rapid increase in GDP and GDP per capita incomes- see Table 3 and Figures 1-4 above. Consequently, due to this economic reform along with the positive contribution of oil in

\footnotetext{
${ }^{11}$ See for instance, the World Bank, (2003), Vol. I: 44.

12 See the United Nations Development Programme UNDP in Sudan (2006) "Macroeconomic Policies for Poverty Reduction: The Case of Sudan," Khartoum, Sudan, 2006.
} 
Sudan economy since 1999, the Sudan turned from a low income economy into a lower medium income economy according to the World Bank classification in the recent years

According to UNDP (2010), prior to the global financial crisis, the Sudanese economy has been one of the fastest growing in the world despite the USA sanctions. The Nominal Gross Domestic Product (GDP) grew from US \$ 9.9 billion (IMF 1980) to US \$ 57.9 billion. ${ }^{13}$ The GDP growth is expected to be around US\$ 52.2 billion in 2009. In recent years, growth rates increased from $7.1 \%$ (2003) to $10.2 \%$ (2007). ${ }^{14}$ However, the global financial crisis and related shock in 2008 and 2009 resulted in low global oil prices, stagnating domestic oil production and caused reduction in GDP growth rate that dropped from 10.5\% in 2007 to $7.8 \%$ and 5\% in 2008 and 2009 respectively-see Table 3 and Figures 1-4 above. A recent IMF report ranked Sudan as one of the most vulnerable low -income countries in the global financial crisis due to its high vulnerability to trade, aid and remittances shocks. IMF adjusted 2009 GDP growth projections for Sudan downwards by 6.7\%, representing the fourth largest adjustment of the 71 low-income countries assessed ${ }^{15}$. Past growth was not sufficiently broad-based, investments and services are concentrated in and around Khartoum state and to a lesser extent Juba, the capital of southern Sudan. The significant disparities between urban and rural areas and between regions contributed to growing inequalities and an increasing urban informal sector accounting for more than $60 \%$ of GDP. This state of affairs has been encouraging a rural-urban migration that might weaken the agricultural productivity, deepen poverty in urban and rural areas (and unemployment in urban area). ${ }^{16}$

Despite the recent impressive real growth and rapid increase in per capita incomes following oil exploitation but emerging vulnerabilities and little progress in social indicators still exist and Sudan still faces formidable economic problems, as yet it is one of the least developed countries in the world and it must rise from a very low level of per capita output. This is evidence from UNDP-Human Development Indicators (2007) and (2009) which indicate that Sudan has scored medium in human development in the last few years, it is classified amongst the bottom of developing countries in terms of HDI, as it ranked 147 and 150 out of 177 developing countries in 2007 and 2009 respectively. ${ }^{17}$ Moreover, as for progress and the status of Millennium Development Goals (MDGs) in Sudan, according to UNDP (2010), while progress has been made towards several of the Millennium Development Goals (MDGs), such as in the area of education, infant and child mortality, access to water and sanitation, Sudan's performance against the MDG indicators demonstrates big inequalities with respect to gender, rural-urban residence, and at the regional and sub-

\footnotetext{
${ }^{13}$ See IMF projection for 2008

${ }^{14}$ See IMF Projection for 2008 and IMF First Review of Performance Under the 2007-2008 Staff-Monitored Program, June 2008, p.2.

${ }^{15}$ See IMF Report on the implications of the Global Financial Crisis for Low-Income Countries, March 2009, p.50

${ }^{16}$ See the UN Millennium Development Goals in Sudan: http://www.sd.undp.org/mdg_sudan.htm, accessed on June 01, 2010.

${ }^{17}$ See http://en.wikipedia.org/wiki/Sudan Accessed June 01 ${ }^{\text {st }}, 2010$
} 
regional level- see Table 4 below. ${ }^{18}$ A rapid acceleration of development efforts is needed if Sudan is to achieve the MDGs by 2015, especially in war-affected areas. Estimated poverty rates remain high with up to 90 percent in Southern Sudan and in the so-called Protocol Areas which are Southern Kordofan, Blue Nile and Abyei. In addition, barely 1 in 5 children complete primary school; clean water is available to only 1 in 4 in some regions and maternal mortality ratio in Southern Sudan is among the highest in the world. Opportunities from economic growth as well as a transition from a humanitarian context to recovery and development are, however, apparent. According to UNDP (2010) due to the global shock, especially regarding oil prices and international lending, but also with respect to expected reductions in FDI, remittances and aid, Sudan is about to face significant financing shortages for its 2009 federal budget, and will have to drastically reduce its public spending, affecting government's capacity to invest in MDGs and poverty reduction. Poverty is widespread in Sudan, for instance, UNDP's 2008 Human Development Report HDR ranked the country 147th among 177 countries compared to position 141 in 2006. According to a 2007 joint World Bank-UNDP mission, about $60-75 \%$ of the population in the North and 90 per cent in the South is estimated to be living below the poverty line of less than US \$ 1 a day. The hardest hit by poverty are people living in rural areas, in particular women and internally displaced people who constitute about $12 \%$ of the population. The lack of formal schooling and high levels of youth unemployment is turning the potential of the young generation from an asset into a challenge for the future. ${ }^{19}$ The low human development indicators implies that Sudan continued to fall below the Arab states and world average level over the past three decades, for instance, the trend of human development index over the period (1980-2010), implies that Sudan's level in 2010 falls below the Arab states and world average level not only in 2010 but also in 1980- see Figure 5 below.

\footnotetext{
${ }^{18}$ The Millennium Declaration and adoption of the United Nations Millennium Development Goals (MDGs) in September 2000 implies commitment towards achievement of the eight MDGs by 2015. The Millennium Development Goals are: (1) Eradicate extreme poverty and hunger: Halve, between 1990 and 2015, the proportion of people whose income is less than one dollar a day, and halve, between 1990 and 2015, the proportion of people who suffer from hunger. (2) Achieve universal primary education: Ensure that, by 2015, children everywhere, boys and girls alike, will be able to complete a full course of primary schooling. (3) Promote gender equality and empower women: Eliminate gender disparity in primary and secondary education, preferably by 2005, and in all levels of education no later than 2015. (4) Reduce child mortality: Reduce by two thirds, between 1990 and 2015, the under-five mortality rate. (5) Improve maternal health: Reduce by three-quarters, between 1990 and 2015, the maternal mortality ratio. (6) Combat HIV/AIDS, malaria and other diseases. (7) Ensure environmental sustainability and (8) Develop a global partnership for development. (See for instance, the UND-HDR).

${ }^{19}$ See The UN Millennium Development Goals in Sudan: http://www.sd.undp.org/mdg_sudan.htm accessed on June 01, 2010
} 
Table (4) - The status of MDGs in Sudan in 2008

\begin{tabular}{|c|c|c|c|c|c|}
\hline MDGs / Indicators & Indicators & $\begin{array}{l}\text { Northern } \\
\text { Sudan }\end{array}$ & $\begin{array}{l}2015 \\
\text { Target }\end{array}$ & $\begin{array}{l}\text { Southern } \\
\text { Sudan }\end{array}$ & $\begin{array}{l}2015 \\
\text { Target }\end{array}$ \\
\hline \multirow{3}{*}{$\begin{array}{l}\text { MDG } 1 \text { Eradicate } \\
\text { Extreme Poverty and } \\
\text { Hunger }\end{array}$} & Estimated poverty incidence (\% of total population) $*$ & $50 \%$ & $45 \%$ & $90 \%$ & $45 \%$ \\
\hline & $\begin{array}{l}\text { Prevalence of child malnutrition (underweight for age; \% } \\
\text { under 5)* }\end{array}$ & $35 \%$ & $16 \%$ & $48 \%$ & $24 \%$ \\
\hline & $\begin{array}{l}\text { Prevalence of acute child } \\
\text { (underweight for weight; \% under 5) }\end{array}$ & $16 \%$ & $8 \%$ & $21 \%$ & $11 \%$ \\
\hline \multirow{3}{*}{$\begin{array}{ll}\text { MDG 2 } & \text { Achieve } \\
\text { Universal } & \text { Primary } \\
\text { Education } & \end{array}$} & Gross primary enrolment ratio*** & $62 \%$ & $100 \%$ & $20 \%$ & $100 \%$ \\
\hline & Percentage of cohort completing primary school*** & $21 \%$ & $100 \%$ & $2 \%$ & $100 \%$ \\
\hline & Adult literacy rate $* *$ & $60-70 \%$ & $25 \% 1$ & $\begin{array}{l}\text { (North and } \\
\text { South) }\end{array}$ & \\
\hline \multirow{3}{*}{$\begin{array}{llr}\text { MDG } 3 & \text { Promote } \\
\text { Gender } & \text { Equality and } \\
\text { Empower Women }\end{array}$} & Ratio girls to boys in primary education*** & $88 \%$ & $100 \%$ & $36 \%$ & $100 \%$ \\
\hline & Women’s literacy rate & $62 \%$ & - & $12 \%$ & - \\
\hline & $\begin{array}{l}\text { Percentage of women in National Assembly/Council of } \\
\text { States }\end{array}$ & $19 \%$ & - & $4 \%$ & $25 \%$ \\
\hline \multirow{3}{*}{$\begin{array}{l}\text { MDG } 4 \text { Reduce Child } \\
\text { Mortality }\end{array}$} & Under-5 mortality rate (per 1,000$)^{*}$ & 105 & 35 & 126 & 83 \\
\hline & Infant mortality rate (per 1,000 live births)* & 70 & - & 89 & - \\
\hline & One-year-olds immunized against measles $* * *$ & $78 \%$ & - & $20.2 \%$ & - \\
\hline \multirow{2}{*}{$\begin{array}{l}\text { MDG } 5 \text { Improve } \\
\text { Maternal Health }\end{array}$} & Maternal mortality ratio (per 100,000 live births) & 638 & 127 & 2,054 & 425 \\
\hline & Birth attended by skilled health staff * & $57 \%$ & $90 \%$ & $5 \%$ & $90 \%$ \\
\hline \multirow{4}{*}{$\begin{array}{l}\text { MDG } 6 \text { Combat HIV } \\
\text { Aids, Malaria and other } \\
\text { diseases }\end{array}$} & Contraceptive prevalence (\% of women ages 15-49)*** & $7 \%$ & - & $<1 \%$ & - \\
\hline & HIV Prevalence (\% adults ages $15-49) *$ & $1.6 \%$ & - & $2.3 \%$ & - \\
\hline & Incidence of TB (per 100,000 per year)*** & 90 & - & 325 & - \\
\hline & Children under 5 with fever treated with anti-malarial (\%) & $54.2 \% *$ & - & $36 \% * * *$ & - \\
\hline \multirow{2}{*}{$\begin{array}{l}\text { MDG } 7 \text { Integrate } \\
\text { principles } \\
\text { sustainable } \\
\text { development } \\
\text { country policies and } \\
\text { programmes; reverse } \\
\text { loss of environmental } \\
\text { resources }\end{array}$} & $\begin{array}{l}\begin{array}{l}\text { Access to improved drinking } \\
\text { population)* }\end{array} \\
\end{array}$ & $58.7 \%$ & $85 \%$ & $48.3 \%$ & $75 \%$ \\
\hline & Access to improved sanitation (\% of population) * & $39.9 \%$ & $67 \%$ & $6.4 \%$ & $53 \%$ \\
\hline $\begin{array}{l}\text { MDG } 8 \text { Develop a } \\
\text { Global Partnership for } \\
\text { development }\end{array}$ & \multicolumn{5}{|c|}{$\begin{array}{l}\text { Progress in Sudan } \\
\text { - The Darfur crisis is currently preventing progress in global partnership, } \\
\text { - To achieve the MDGs, Sudan will need to make significant investments to build the capacity of human resources, } \\
\text { infrastructure and institutions as well as to mobilize resources to bridge the financial gap. } \\
\text { - It is necessary that a continuous and sustained effort by the Sudanese people, its governments, and the } \\
\text { international community is exerted to achieve MDG8. }\end{array}$} \\
\hline
\end{tabular}

Sources: This document has been prepared by the UN Resident Coordinator's Support Office, Khartoum, Sudan:

http://www.sd.undp.org/mdg_fact.htm, accessed in June 01, 2010.

Notes: *Sudan Health and Household Survey 2006; ** EFA Global Summary Report 2008 p.17.

*** Sudan Millennium Development Goals. Interim Unified Report, 2004.

Figure (5) - Human Development Index: Trends in (1980 - 2010) in Sudan Compared to Arab States and World

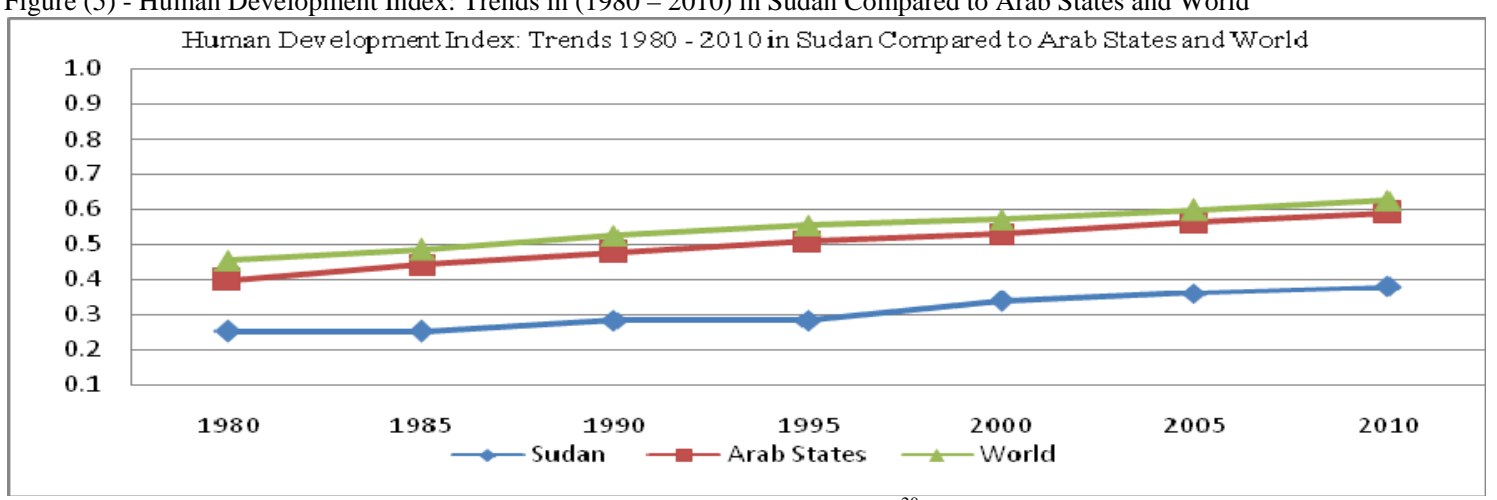

Source: UNDP Sudan Country profile of Human Development Indicators (2010) ${ }^{20}$

\section{Overview on the importance and impacts of oil in Sudan}

Based on the above background on the socio-economic characteristics of Sudan economy and since the structure of Sudan economy is now related to oil, so in the next section it will be useful to explain the impact of oil in Sudan economy, notably, to examine if oil has affected

\footnotetext{
${ }^{20}$ See UNDP (2010): http://hdrstats.undp.org/en/countries/profiles/SDN.html, accessed on December 22, 2010.
} 
the general socio- economic characteristics presented in the above section. Before explaining the various positive and negative impacts of oil in Sudan economy, it will be useful to start with a historical background about the structure, investment, exploration and production of oil in Sudan.

\section{1. Overview on the importance and historical background about oil in Sudan}

In 1999 significant oil production started and Sudan become one of the newest significant oil producing countries in the world and is now the third largest oil producer in Sub-Saharan Africa, behind Nigeria and Angola, with output at about 500,000 barrels per day in 2007. Two main blends of crude oil are currently produced—Nile Blend and Dar Blend-with varying quality between fields- see Figure 6 below. Production forecasts are difficult for Sudan given the lack of detailed information regarding specific major new and ongoing projects, but available data suggests peak production in the next few years before a gradual decline. ${ }^{21}$ Sudan's oil proven reserves are estimated at 270 million barrels in 2003 and 1.6 billion bbl in 2005. The officials claim that proven reserves account for only $15 \%$ of national oil reserves. Moreover in 2005, the Sudanese Energy Ministry estimates total oil reserves at 5 billion barrels. Vast potential reserves are held in northwest Sudan, the Blue Nile Basin, and the Red Sea area in eastern Sudan. The major oil production fields are located in the south, the major oil refineries, ports and pipelines are located in the north, due to conflict, oil exploration has been mostly limited to the central and south-central regions of the country. ${ }^{22}$

Figure 6- Country Comparison Crude Oil Production in Sub-Saharan Africa 2005

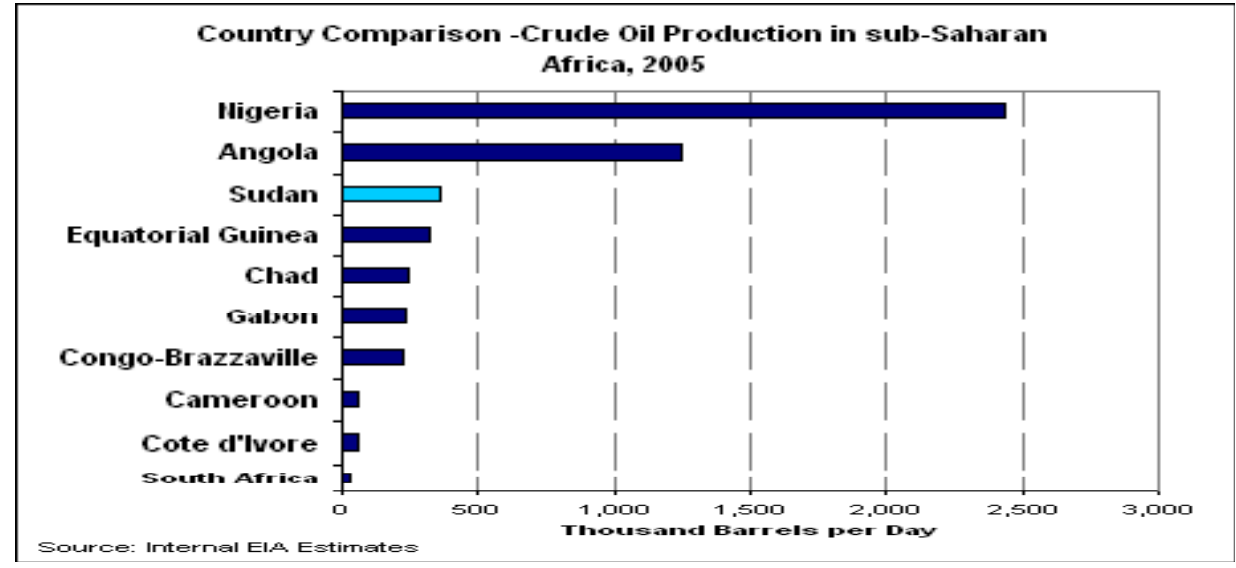

Source: Energy Information Agency, Sudan Analysis, www.eia.doe.gov/cabs/Sudan/Oil.html ${ }^{23}$

\footnotetext{
${ }^{21}$ See WB-DTIS, (2008), p.2.

${ }^{22}$ The major oil production fields are located in the south in Heglig/Unity, Adar, Muglad Basin, Merut Basin. The major oil refineries are located in the north in Khartoum, El Gily, Port Sudan and El Obeid and the major Oil Ports is the Bashair Sea Port and Port Sudan Sea Port both are located in the Red Sea in the north. The major oil pipelines include a pipeline from Heglig and Unity fields to the Suakin oil terminal; a pipeline from Melut Basin to Port Sudan and a pipeline linking the Thar Jath and Mala fields to Port Sudan.- See Sudan Factsheet Human Rights and Oil workshop - January 31, 2003, pp. 1-2; see also Oil fact sheet on Sudan, September 2006, pp. 1-2, and International Energy Agency Estimates; International Energy Annual, IPM

${ }^{23}$ See Oil fact sheet on Sudan, September 2006, p. 1, International Energy Agency Estimates; International Energy Annual, IPM.
} 
The historical background about the institutional structure of oil sector in Sudan indicates that the oil industry is regulated by the Ministry of Energy and Mining, yet the Ministry of Finance and Planning is also involved. The representatives of the ministry are members of the Petroleum Affairs Board which is responsible for final approval of petroleum contracts. Control over daily proceedings in oil industry is exercised by the Exploration and Production Authority, a state-owned entity. The board grants concessions for oil exploration and development. More recently, after the implementation of CPA a new National Petroleum Commission is formed, the function of the commission is to allocate new oil contracts, and to ensure an equal sharing of oil revenues between the northern and the southern Sudan. ${ }^{24}$

As for the organization structure of oil sector in the Sudan, since long the organization of oil sector in Sudan implies the involvement of several foreign international companies in oil production in Sudan. This includes for example Agib from Italy (1959); Chevron from USA (1974- 1992); Texas Eastern (USA); Union Texas (USA); Total from France; Oceanic Oil Company; the Talisman Energy (Canada), OMV (Austria), China National Petroleum Corporation (CNPC), Gulf Petroleum Corporation (GPC), Lundin Oil AB, Petronas (Malaysia), Royal Dutch/Shell (Netherlands), India’s Oil \& Natural Gas; Marathon Oil Corporation, the Kuwait Foreign Petroleum Company, and Total SA are also involved, but the latest hasn't started to exploit yet. ${ }^{25}$ More recently, the organization structure of oil sector in Sudan indicates the involvement of national and foreign companies. For instance, Sudan National Petroleum Corporation (Sudapet) is the national petroleum company or agency that is actively involved in oil exploration and production in Sudan. Sudapet also develops joint ventures with foreign companies in downstream projects. However, due to its limited technical and financial resources, the company takes a minor role in large upstream development projects. In recent years, foreign companies involved in Sudan's oil sector are primarily from Asia. They are led by China National Petroleum Corporation (CNPC), which owns the biggest single share in the consortium of the GNPC(40\%); India's Oil and Natural Gas Corporation (ONGC), and Malaysia's Petronas (with a share of 30\% in the consortium).

Historically, from 1959 to 1974, Agip from Italy started in 1959 focused oil exploration in the concession area in the Red Sea, Oceanic Oil Company, Total, Texas Eastern, Union Texas and Chevron drilled in concessions granted in the Red Sea area with few results. ${ }^{26}$ The first attempt for oil exploration in Sudan started in 1959 in the Red Sea basin undertaken by Agip Company, but due to lack of modern equipment and poor technical facilities the results were negative. But when the Chevron international company acquired the

\footnotetext{
${ }^{24}$ See Sudan Factsheet Human Rights and Oil workshop - January 31, 2003, pp. 1-2; see also Oil fact sheet on Sudan, September 2006, pp. 1-2. See also www.eia.doe.gov/cabs/Sudan/Oil.html.

${ }^{25}$ See Sudan Factsheet Human Rights and Oil workshop-January 31, 2003, pp. 1-2, see also Oil fact sheet on Sudan, September 2006 Produced by C. Pinaud for UnderstandingSudan.org, 2006, pp. 1-2.

${ }^{26}$ See Sudan Factsheet Human Rights and Oil workshop-January 31, 2003, pp. 1-2, see also Oil fact sheet on Sudan, September 2006 Produced by C. Pinaud for UnderstandingSudan.org, 2006, pp. 1-2.
} 
concession in the same oil field and due to its high facilities and capabilities it was able to discover oil for the first time in the field of Bashair and Suakin in the northeast Sudan. By this concession Chevron intensified its exploration activities in other parts of Sudan and in 1979 it indicated the discovery of the first field in the south in the basin of Hegleig and unity in addition to other fields. During the involvement of Chevron, the Dutch Shell company decided to involve with Chevron by acquiring about $25 \%$ of total oil exploration activities in the country in 1984; (Royal Dutch/Shell runs Khartoum refinery). Chevron Company continues its work and attempts between 1976-1979 and it has exerted good efforts in exploration process and activities, and it has indicated that it spent about thousand million dollar in the exploration activities in Sudan using the heavy machines and equipment, most latest recent techniques, modern technologies and scientific methods which gives the impression of near successful oil production in Sudan at that time. Chevron began exploration and acquired concessions in southern Sudan in 1975; it made its first discovery in the Unity oilfield north of Bentiu in 1978. Over the period the 1985-1989 Chevron oil exploration activities in the south were constrained by the active movement of rebellion of SPLM and begin of the conflict and war again in 1983 and rebels attacked Chevron's southern headquarters killing three expatriates. Chevron suspended all southern activities then and never returned to Sudan again and even closed some sites with large concrete blocks and buried Sudanese oil discovered wells by bricks and concrete blocks. Chevron surrendered all of its concessions in 1992 and attributed that to both the lack of security and economic loss that occurred to Chevron due to rebellion SPLM attack Chevron oil fields. In 1992, Chevron sold its concession to the Sudanese government for US\$18 million in cash, while Chevron has previously spent thousand million in oil exploration in Sudan. During that time beside Sudan government, IPC and Total companies are working in oil exploration activities in Sudan. In 1993 State Petroleum Company reported a potential success in producing 10000 barrel per day in June 1996. But then after sometime the State petroleum stopped its work and sold its concession to Talisman Energy (Canada) from Canada. By the end of 1996 and begin of 1997 the door was opened for international oil companies to invest in oil exploration in Sudan. As a result the consortium of Greater Nile Petroleum Operating Companies was emerged and it includes many oil producing companies. The consortium is composed of China National Petroleum Company (CNPC: 40\%), Malaysia Petronas company (30\%); Sudan Government SudaPet company (5\%) and the Sate petroleum company before selling its concession to Talisman Energy (Canada) for 25\%. ${ }^{27}$ Since 1991, the main Red Sea concession has been held by Lundin Oil. In March 1999, Lundin Oil reported a substantial find in Block 5A with minority stakeholders Petronas, OMV of Austria, and Sudapet. Petronas acquired a $40 \%$ share in block 5B; neither Block 5A nor 5B is in production due to war. Arakis Energy Corporation

\footnotetext{
${ }^{27}$ See Salih, (2004), pp. 21-40.
} 
bought the Heglig and Unity concessions in 1993, but was unable to raise the capital for a pipeline project alone. It created a joint-operating company in 1996 called the Greater Nile Oil Project (China National Petroleum Corporation (40\%); Petronas Malaysia (30\%); Arakis (25\%) and Sudapet (5\%)) to construct the pipeline, build the supertanker put on the Red Sea and develop the project. Talisman (formerly BP-Canada) took over the Arakis' interest in 1998, but faced a backlash of human rights protest. Most recently, India’s Oil \& Natural Gas Corporation Ltd. agreed to acquire Talisman's interest for $\$ 758$ million. ${ }^{28}$ Therefore, this implies that in recent years, foreign companies involved in Sudan's oil sector are primarily from Asia. They are led by China National Petroleum Corporation (CNPC), which owns the biggest single share in the consortium of GNPC (40\%) as we will explain below in the next section.

\section{2. The role of China in the exploration, production and exportation of Sudanese Oil}

China is the major player in the Sudanese oil industry, China uses a combination of investment, trade, aid flows and diplomacy channels to foster long-term partnerships with Sudan that possess resources it wants to obtain, especially petroleum. ${ }^{29}$ This section provides an assessment of the importance, growth, structure, trend and distribution of Chinese investment (notably investment in oil sector), trade and aid and development assistance to Sudan over the period (1997-2010). For instance, Tables 5-13 show total Chinese investment in oil, trade and aid to Sudan over the period (1999-2010).

\section{2. 1. China investment in oil sector in Sudan}

To explain the importance of China oil and non-oil investment compared to foreign oil and non-oil investment in Sudan, we use quantitative secondary data on the share of China oil and non-oil investment relative to total foreign oil and non-oil investment in Sudan over the period (1997-2008).

Beginning with China investment in non-oil sectors, according to an unpublished data from Sudan's Ministry of Investment, apart from oil, the Chinese non oil investment contributed to foreign investment implemented by all foreign countries in different sectors in Sudan during the period (2000-2007). For instance, the estimated value of China investment

\footnotetext{
${ }^{28}$ See Sudan Factsheet Human Rights \& Oil workshop-January 31, 2003. pp 1-2.

${ }^{29}$ Ali (2007) indicates that Sudan's recent relationship was activated after China had gone through the structural change by its entry into the market system after more than fifty years of isolation. Moreover it became a very effective member of the international community and a member of the Security Council with a Veto right. China took the chance of being invited to explore Sudan's oil potential, although China came within an oil Consortium, but remained the senior partner. When it came to the oil business in Sudan China was already growing at about $10 \%$ annual growth and hungry for every kind of raw material specially oil because its own reserves dwindled. In fact Sudan became a spring board for China because after Sudan, China moved to Libya, Algeria, Mauritania, Nigeria Guinea etc. China purchased about 81\% of Sudan's crude during the years 20012004. Now China is Sudan major trading partner after this position alternated between the EU and Saudi Arabia, and maybe the second after South Africa. Sudan exports in 2006 went up to US \$ 4.2 billion representing 75\% of Sudan’s total exports. Total exports of oil amounted to US \$ 5.1 billion out of which China got US \$ 4.1 billions, $82.3 \%$ of total exports of oil. Imports from China reached US \$ 1.7 billion out of total imports of US\$ 8.1 billion. Therefore, the trade balance is in favour of Sudan, but China seems to press hard to increase its exports to Sudan to reduce the trade balance. Sudan's imports from other Asia amounted to US\$ 2.7 billions in the same year 2006. The numbers of Chinese workers in the various projects in Sudan are no less than
} 
in total, petroleum, industrial, services and agricultural are equivalent to US\$6005774 thousand, US\$6000000 thousand, US\$4040.5 thousand, US\$1728.5 thousand and US\$5.0 thousand respectively. This implies that the share of China in total foreign investment by all foreign countries implemented in different sectors in Sudan during the period (2000-2007) is equivalent to $47.63 \%, 0.56 \%, 0.08 \%, 0.02 \%$ and $38.67 \%$ of total foreign investment by all foreign countries in petroleum, industrial, services, agricultural and total sectors respectively. This also implies that the large share of Chinese investment is concentrated in petroleum and oil sector, for instance, the distribution of total Chinese investment in different sectors in Sudan during the period (2000-2007), implies the biased distribution, since the share of petroleum, industrial, services and agricultural sectors in total Chinese investment in all sectors are $99.90 \%, 0.07 \%, 0.03 \%$ and $0.0001 \%$ respectively. Therefore, this implies that it is particularly useful to focus our analysis to China investment in oil sector in Sudan. ${ }^{30}$

To explain the importance of China investment in oil sector in Sudan compared to foreign oil investment from other countries in Sudan, we use quantitative secondary data on the share of Chinese oil investment relative to (as percentage of) total foreign oil investment from other countries in Sudan over the period (1997-2008). For instance, Tables 5-10 show that the significant Chinese investment in oil sector in Sudan over the period (1999-2008) is evidenced from the share of China in oil concession, investment in up-stream and downstream oil, investment in pipe lines of oil, investment in refinery of oil and investment in marketing, industry and manufacturing of oil sector in Sudan.

Beginning with the concession in oil sector in Sudan; among Asian countries the share of China in concession on investment in oil sector in Sudan is significant over the period (1999-2008). For instance, recent report by Ministry of Energy and Mining (2008) shows significant large Chinese investment and concession in oil sector that includes many Chinese companies and extends to many blocks. For example, we observe significant share of China (China National Petroleum Company (CNPC) 40\%), compared to Malaysia (Petronas 30\%), India (ONGS 25\%), and Sudan (Sudapet 5\%) of total concession in the Greater Nile Petroleum Operating Company (GNPOC) in blocks 1, 2 and 4. In addition to significant share of China (CNPC 41\% and Sinopec 6\%), compared to Malaysia (Petronas 40\%), UAE (Thani 5\%) and Sudan (Sudapet 8\%) of total concession in Petrodar Petroleum Operating Company (PDOC) in blocks 3\&7. In addition to significant share of China (CNPC 95\%) compared to the share of Sudan (Sudapet 5\%) of total concession in China National Petroleum Company International Sudan (GNPCIS) in block 6. In addition to significant share of China (Petroenergy 40\%), compared to Indonesia (Petramina 15\%), Sudan (Sudapet 15\%), Nigeria

30 Adapted from Sudan Ministry of Investment unpublished statistics and data from the feasibility studies (2009). 
(Express 10\%), Nigeria (Africa Energy 10\%) and Sudan (Dindir 10\%) of total concession in Group of Companies in block 13. In addition to significant share of China (Petroenergy 35\%), compared to Malaysia (Petronas 35\%), Sudan (Sudapet 15\%), Nigeria (Express 10\%) and Sudan (Hi Tech 5\%) of total concession in Red Sea Oil Company in block 15.

\begin{tabular}{|c|c|c|c|c|}
\hline \multicolumn{5}{|l|}{ Company } \\
\hline & Block & $\%$ & Country & Company \\
\hline \multirow[t]{5}{*}{ Greater Nile Petroleum Operating Company (GNPOC) } & $1,2 \& 4$ & & & \\
\hline & & $40 \%$ & China & CNPC \\
\hline & & $30 \%$ & Malaysia & Petronas \\
\hline & & $25 \%$ & India & ONGC \\
\hline & & $5 \%$ & Sudan & Sudapet \\
\hline \multirow[t]{6}{*}{ Petrodar Petroleum Operating Company (PDOC) } & $3 \& 7$ & & & \\
\hline & & $41 \%$ & China & CNPC \\
\hline & & $40 \%$ & Malaysia & Petronas \\
\hline & & $5 \%$ & UAE & Thani \\
\hline & & $6 \%$ & China & Sinopec \\
\hline & & $8 \%$ & Sudan & Sudapet \\
\hline \multirow[t]{3}{*}{ China National Petroleum Company International Sudan (GNPCIS) } & 6 & & & \\
\hline & & $95 \%$ & China & CNPC \\
\hline & & $5 \%$ & Sudan & Sudapet \\
\hline \multirow[t]{7}{*}{ Group of Companies } & 13 & & & \\
\hline & & $40 \%$ & China & PETROENERGY \\
\hline & & $15 \%$ & Indonesia & Petramina \\
\hline & & $15 \%$ & Sudan & Sudapet \\
\hline & & $10 \%$ & Nigeria & Express \\
\hline & & $10 \%$ & Nigeria & Africa Energy \\
\hline & & $10 \%$ & Sudan & Dindir \\
\hline \multirow[t]{6}{*}{ Red Sea Oil Company } & 15 & & & \\
\hline & & $35 \%$ & China & PETROENERGY \\
\hline & & $35 \%$ & Malaysia & Petronas \\
\hline & & $15 \%$ & Sudan & Sudapet \\
\hline & & $10 \%$ & Nigeria & Express \\
\hline & & $5 \%$ & Sudan & Hi Tech \\
\hline
\end{tabular}

According to Sudan Ministry of Energy and Mining (2008), China investment in oil sector is diversified including up-stream and down-stream oil sector in Sudan. For instance, within Asian countries, China grand total investment in oil sector in Sudan over the period (19992008) is equivalent to US\$6003.15 Million, including total investment in up-stream equivalent to US\$40723 Million and total investment in down-stream equivalent to US\$1930.85 Million. This implies that the share of China represents 47.3\%, 43.8\% and $56.9 \%$ of Asian countries total investment in grand total, in up-stream and in down-stream oil sector in Sudan respectively. The Chinese share represents $47.3 \%$, compared to the share of total Asia in total foreign investment in oil $84.4 \%$. The Asian countries investing in Sudanese oil sector includes China, Malaysia, India, UAE, Pakistan, Kuwait and Iran. In particular, Chinese company (CNPC+SINOPEC) invested US\$40723 Million, which account for $43.8 \%$ of total Asian countries investment in up-stream oil sector in Sudan over the period (19992008), which accounted for $84.4 \%$ as the share of total Asia in total foreign investment in upstream oil sector in Sudan over the period (1999-2008).

\begin{tabular}{|c|c|c|c|c|c|c|c|}
\hline \multirow{3}{*}{ Country } & \multicolumn{4}{|l|}{ Total investment } & \multicolumn{3}{|c|}{ \% in Total investment in } \\
\hline & \multicolumn{2}{|c|}{ Total investment in up-stream } & \multirow{2}{*}{$\begin{array}{l}\text { Down- } \\
\text { Stream }\end{array}$} & \multirow{2}{*}{$\begin{array}{ll}\begin{array}{l}\text { Grand } \\
\text { investment }\end{array} & \text { total } \\
\end{array}$} & \multirow{2}{*}{$\begin{array}{l}\text { Up- } \\
\text { Stream }\end{array}$} & \multirow{2}{*}{$\begin{array}{l}\text { Down- } \\
\text { Stream }\end{array}$} & \multirow{2}{*}{$\begin{array}{l}\text { Grand } \\
\text { total }\end{array}$} \\
\hline & Company & investment & & & & & \\
\hline China & CNPC+SINOPEC & 40723 & 1930.85 & 6003.15 & $43.8 \%$ & $56.9 \%$ & $47.3 \%$ \\
\hline Malaysia & PETRONAS & 3377.7 & 872.8 & 4250.5 & $36.3 \%$ & $25.7 \%$ & $33.5 \%$ \\
\hline India & ONGC & 1652.3 & 511 & 2163.3 & $17.8 \%$ & $15.1 \%$ & $17.1 \%$ \\
\hline UAE & THANI & 107.9 & 63 & 170.9 & $1.2 \%$ & $1.9 \%$ & $1.3 \%$ \\
\hline Pakistan & ZPG & 60.7 & - & 61 & $0.7 \%$ & - & $0.5 \%$ \\
\hline Kuwait & KUAWIT & 21.5 & - & 21.5 & $0.2 \%$ & - & $0.2 \%$ \\
\hline Iran & & - & 15 & 15 & - & $0.4 \%$ & $0.1 \%$ \\
\hline Total Asia & & 9292.4 & 3392.65 & 12685.05 & $100 \%$ & $100 \%$ & $100 \%$ \\
\hline total foreign investment in oil & & 10665.5 & & & & & \\
\hline Total Asia/total all foreign investment in oil & & $84.4 \%$ & & & & & $84.4 \%$ \\
\hline
\end{tabular}


In particular, China significant investment in up-stream oil sector in Sudan over the period (1999-2008), is obvious from the contribution of China (SINOPEC) investment equivalent to US\$129.4 Million in PDOC in blocks 3\&7, China (CNPC) investment equivalent to US\$2146.8 Million in GNPOC in blocks 1,2\&4, investment equivalent to US\$884.5 Million in PDOC in blocks 3\&7, investment equivalent to US\$906.0 Million in Petroenergy in block 6 and equivalent to US\$5.6 Million in RESPOC in block 15. This implies that the total China investment in up-stream oil sector in Sudan is equivalent to US\$3942.9 Million of total Asian investment in up-stream oil sector in Sudan that equivalent to US\$9292.4 Million. In addition, China significant investment in oil sector in Sudan also appears from expenditure. For instance, recent report by Ministry of Energy and Mining (2008) shows significant share of Chinese companies in total expenditure of oil operating companies in oil sector in Sudan over the period (1993-2007) GNPOC (53.46\%), PDOC (21.50\%), PETROENERGY (9.50\%), WNPOC (12.01\%), WNPOC (0.84\%), WNPOC (0.62\%), SUDPAK (0.47\%), SUDPAK (0.18\%), SUDPAK (0.07\%), TOTAL (0.26\%), APCO (0.94\%) and RSPOC (0.16\%).

\begin{tabular}{|c|c|c|c|c|c|c|c|c|c|c|c|c|c|}
\hline \multirow[b]{2}{*}{ Company } & \multirow[b]{2}{*}{ Country } & \multicolumn{11}{|c|}{ Share in Consortium investment in Up- Stream } & \multirow[t]{2}{*}{ Total } \\
\hline & & $\begin{array}{l}\text { GNPOC } \\
1,2 \& 4\end{array}$ & $\begin{array}{l}\text { PDOC } \\
3 \& 7 \\
\end{array}$ & $\begin{array}{l}\text { PETROEN } \\
\text { ERGY } 6\end{array}$ & $\begin{array}{l}\text { WNPO } \\
\text { C 5A }\end{array}$ & $\begin{array}{l}\text { WNPOC } \\
5 \mathrm{~B}\end{array}$ & $\begin{array}{l}\text { WNPOC } \\
8\end{array}$ & $\begin{array}{l}\text { SUDAP } \\
\text { AK } 9\end{array}$ & $\begin{array}{l}\text { SUDAP } \\
\text { AK } 11\end{array}$ & $\begin{array}{l}\text { SUDPA } \\
\text { K A }\end{array}$ & $\begin{array}{l}\text { TOTAL } \\
\text { B }\end{array}$ & $\begin{array}{l}\text { RESP } \\
\text { OC } 15\end{array}$ & \\
\hline CNPC & China & 2146.8 & 884.5 & 906.0 & & & & & & & & 5.6 & 3942.9 \\
\hline SINOPEC & China & & 129.4 & & & & & & & & & & 129.4 \\
\hline PETRONAS & Malaysia & 1610.1 & 862.9 & & 818.2 & 32.7 & 48.2 & & & & & 5.6 & 3377.7 \\
\hline ONGC & India & 1341.8 & & & 290.8 & 19.7 & & & & & & & 1652.3 \\
\hline ZPG & Pakistan & & & & & & & 40.0 & 15.1 & 5.6 & & & 60.7 \\
\hline THANI & UAE & 107.9 & & & & & & & & & & & 107.9 \\
\hline KUAWIT & Kuwait & & & & & & & & & & 21.5 & & 21.5 \\
\hline \multicolumn{2}{|c|}{ TOTAL (1999-2008) } & 5026.6 & 1876.8 & 906.0 & 1109.0 & 52.4 & 48.2 & 40.0 & 15.1 & 5.6 & 21.1 & 11.2 & 9292.4 \\
\hline \multicolumn{2}{|c|}{ \% in TOTAL (1993-2007) } & $53.46 \%$ & $21.50 \%$ & $9.50 \%$ & $12.01 \%$ & $0.84 \%$ & $0.62 \%$ & $0.47 \%$ & $0.18 \%$ & $0.07 \%$ & $0.26 \%$ & $0.16 \%$ & \\
\hline
\end{tabular}

In addition to China significant investment in pipe lines of oil sector in Sudan (1999-2008), China investment is equivalent to US\$1333.8 Million compared to Sudan and other Asian countries investment that equivalent to US\$2950.2 Million. China investment implemented by (CNPC) investment in Hejlij- Bashaire pipe line is equivalent to US\$488 Million, AlfoulaAlgeli pipe line is equivalent to US\$366 Million and Floug- Bashaire pipe line is equivalent to US\$479.8 Million and China (SINOPEC) Floug- Bashaire pipe line is equivalent to US\$70.2 Million. The share of China that equivalent to $47.6 \%$ of total Asia is implemented by (CNPC) equivalent to $45.2 \%$ and China (SINOPEC) equivalent to $2.4 \%$ of total Sudanese and other Asian countries investment in pipe lines of oil sector in Sudan during (1999-2008).

Table (8) Asian countries and China investment in pipe lines of oil sector in Sudan (1999-2008) (in Million US\$)
\begin{tabular}{|l|l|l|l|l|l|l|l|}
\hline & CNPC & SINOPEC & PETRONAS & ONGC & THANI & SUDAPET & Total \\
\hline & China & China & Malaysia & India & UAE & Sudan & \\
\hline Hejlij- Bashaire pipe line & 488 & - & 366 & 305 & - & 61 & \\
\hline Alfoula- Algeli pipe line & 366 & - & - & - & - & - & 1220 \\
\hline Floug- Bashaire pipe line & 479.8 & 70.2 & 468.1 & - & 58.5 & 93.6 & 366 \\
\hline Benzene exports pipe line (Khartoum-Port Sudan) & - & - & - & 194 & - & - & 170.2 \\
\hline Total & 1333.8 & 70.2 & 834.1 & 499 & 58.5 & 154.6 & 194 \\
\hline$\%$ in total & $45.2 \%$ & $2.4 \%$ & $28.3 \%$ & $16.9 \%$ & $2.0 \%$ & $5.2 \%$ & 2950.2 \\
\hline$\%$ of China/total Asia & $47.6 \%$ & & & & $100.0 \%$ \\
\hline
\end{tabular}
Source: Sudan Ministry of Energy and Mining 2008


Furthermore, China investment is significant in refinery of oil sector in Sudan over the period (1999-2008). For instance, China (CNPC) and Sudan (Sudan government) made partnership for the establishment of Khartoum refinery, of total establishment cost equivalent to US\$640 Million; they contribute by equivalent share of $50 \%$ and $50 \%$ that equivalent to US\$320 Million and US\$320 Million. In addition China (CNPC) and Sudan (Sudan government) extend their partnership to Khartoum refinery expansion, of total expansion cost equivalent to US\$350 Million; they contribute by equivalent share of $50 \%$ and $50 \%$ that equivalent to US\$175 Million and US\$175 Million. Moreover, in petrochemicals factory, the significant investment and contribution of China (CNPC) is equivalent to US\$21.85 Million and the share of China (CNPC) is equivalent to 95\% compared to Sudan (Sudan government) contribution equivalent to US\$1.15 Million and share of $5 \%$ of total investment in petrochemicals factory equivalent to US\$23 Million. This implies that of total investment in Khartoum refinery, its expansion and in petrochemicals factory equivalent to US\$1013 Million, the contribution and share of China (CNPC) is equivalent to US\$516.85Million and $51 \%$, while the contribution and share of Sudan (Sudan government) is equivalent to US\$496.15Million and 49\%.

Table (9) China investment in refinery of oil sector in Sudan (1999-2008) (in Million US\$)
\begin{tabular}{|l|l|l|l|l|l|}
\hline & CNPC & Sudan government & Total & $\%$ China & $\%$ Sudan \\
\hline & China & Sudan & & & \\
\hline Khartoum refinery & 320 & 320 & 640 & $50 \%$ & $50 \%$ \\
\hline Khartoum refinery expansion & 175 & 175 & 350 & $50 \%$ & $50 \%$ \\
\hline Petrochemicals factory & 21.85 & 1.15 & 23 & $95 \%$ & $5 \%$ \\
\hline Total & 516.85 & 496.15 & 1013 & $51 \%$ & $49.0 \%$ \\
\hline$\%$ in total & $51 \%$ & $49.0 \%$ & $100.0 \%$ & & \\
\hline
\end{tabular}
Source: Sudan Ministry of Energy and Mining 2008

In addition to significant investment of China and other Asian countries in marketing, industry and manufacturing of oil sector in Sudan over the period (1999-2008). For instance, of total Asian countries investment equivalent to US\$80.2 Million in marketing, industry, manufacturing of oil sector in Sudan (1999-2008), the significant share and investment by China (Kandoc petrochemical 12.5\%) is equivalent to US\$10 Million, compared to Malaysia (Petronas 48.3\%) investment equivalent to US\$38.7 Million, Iran (Benasag Iran Gas 18.7\%) investment equivalent to US\$15 Million, India (Gapco 14\%) investment equivalent to US\$12 Million and the UAE (SudaGas 5.6\%) investment equivalent to US\$4.5 Million.

\begin{tabular}{|c|c|c|c|}
\hline Company & Country & Total Investment & \% In Total Investment \\
\hline PETRONAS & Malaysia & 38.7 & $48.3 \%$ \\
\hline Benfasag Iran Gas & Iran & 15 & $18.7 \%$ \\
\hline Gapco & India & 12 & $14 \%$ \\
\hline Kandoc petrochemical & China & 10 & $12.5 \%$ \\
\hline Suda Gas & UAE & 4.5 & $5.6 \%$ \\
\hline TOTAL & & 80.2 & $100 \%$ \\
\hline
\end{tabular}

\section{2. 2. China investment in oil sector in Sudan and China-Sudan trade relationships}

The significant China investment in oil sector in Sudan has motivated the trade relations between Sudan and China, hence, widespread trade with China is occurring, as China buys oil 
from Sudan and in turn, Sudan has brought many items from China, fueling their economies. To explain the importance of the Chinese trade with Sudan compared to other foreign countries trade with Sudan, we use quantitative secondary data on the share of Chinese trade (exports and imports) with Sudan relative to (as percentage of) total foreign trade (exports and imports) of other countries with Sudan economy over the period (1997-2010). For instance, Tables 11-12 shows the total Chinese trade (exports and imports measured by commodities) in Sudan over the period (1999-2010). Over the period (1997-2010) the total volume of exports and imports between Sudan and China is equivalent to US\$ 39.241Millions and is equivalent to US\$ 11.576 Million respectively. Over the period (1997-1999) the trade balance is in favor of China, whereas after that over the period (2000-2010) the trade balance turned to be in favor and advantage of Sudan and deficit to China increased from US\$ 615 Millions in 2000 to US\$2603 Millions in 2007. The overall balance is in favor of Sudan and it is equivalent to US\$4.278 Millions. This is not surprising given the increase in oil exports to China as we will explain below. ${ }^{31}$ According to data and statistics from the Central Bank of Sudan during the period (2000-2010) the value and share of China is significant in Sudan foreign trade compared to main importers to and exports from Sudan. For instance, the share of China in Sudan total exports to all foreign countries are 44.1\%, 59\%, 65.74\%, 69.31\%, 66.89\%, 71.04\%, 75.03\%, 81.95\%, 75.02\%, 75.77\% and 81.42\% in 2000, 2001, 2002, 2003, 2004, 2005, 2006, 2007, 2008, 2009 and 2010 respectively. The share of China in Sudan total imports from all foreign countries are 6.56\%, 10.66\%, 8.02\%, 7.95\%, 13.00\%, 14.79\%, $19.14 \%$, 30.18\%, 32.02\%, 19.88\% and 14.16\% in 2000, 2001, 2002, 2003, 2004, 2005, 2006, 2007, 2008, 2009 and 2010 respectively. The average share of China in Sudan total exports and imports over the period (2000-2010) is $69.56 \%$ and $15.67 \%$ respectively.

Table 11 below shows Sudan exports to China and it implies that Sudan exports to China include limited commodities and for few commodities Sudan exports to China rapidly increased during the period (1997-2010). As for petroleum and petroleum products, according to data and statistics from the Central Bank of Sudan during the period (2000-2010) the value and share of China is significant in Sudan exports compared to main exporters from Sudan. For instance, the share of China in Sudan total exports of petroleum and petroleum products to all foreign countries are 58.87\%, 72.78\%, 85.03\%, 84.99\%, 80.64\%, 80.86\%, 82.30\%, $86.16 \%$, 78.85\%, 82.63\%, and 87.70\%, in 2000, 2001, 2002, 2003, 2004, 2005, 2006, 2007, 2008, 2009 and 2010 respectively. Over the period (2000-2010) the share of China in Sudan total exports of petroleum and petroleum products is equivalent to $80.07 \%$. Over the period (1997-2010) the share of petroleum and petroleum products in Sudan total exports to China

\footnotetext{
${ }^{31}$ See Sudan Ministry of Finance and National Economy (2008) Unpublished Report (2008), and Central Bank of Sudan 44 ${ }^{\text {th }}$ Annual Report (2004): Appendix No. XVI, pp. 188-189; and 48 ${ }^{\text {th }}$ Annual Report (2008): Appendix No. XVI-B-XVIIB, pp.158164.
} 
are $0.00 \%, 0.00 \%, 0.00 \%, 99.76 \%, 99.98 \%, 99.91 \%, 98.77 \%, 98.94 \%, 98.80 \%, 98.86 \%$, 99.68\%, 99.92\%, 99.29\% and 99.53\% in 1997, 1998, 1999, 2000, 2001, 2002, 2003, 2004, 2005, 2006, 2007, 2008, 2009 and 2010 respectively. Over the period (2000-2010) the share of petroleum and petroleum products in Sudan total exports to China is equivalent to $99.40 \%$. As for the other non-oil exports, over the period (2000-2010) the average share of China in Sudan exports to all foreign countries in other non-oil commodities include cotton (7.75\%), gum Arabic (0.34\%), sesame (10.49\%), skins and hide (5.37\%) and others (2.31\%). This implies that the petroleum and petroleum products dominates Sudan's exports to China (99.4\%), while all other non-oil exports to China represents only (0.6\%). This also implies that China is the largest importer of Sudan's petroleum and petroleum products (80.07\%), while Sudan export of petroleum and petroleum products to all other countries represents only $(19.93 \%)$

As for Sudan imports from China, Table 12 shows that imports to/for Sudan from China are diversified by commodities that rapidly increased for many commodities during the period (1997-2010). Over the period (2000-2010) the average share of China in Sudan total imports from all foreign countries for various commodities include coffee and tea $(0.07 \%)$, wheat and wheat flour (5.50\%), other food stuff (3.89\%), beverage and tobacco (8.29\%), petroleum products $(0.002 \%)$, crude materials $(3.16 \%)$, chemicals $(11.31 \%)$, manufactured goods (21.01\%), machinery and equipment (20.63\%), transport equipment (13.59\%), and textiles (35.43\%). In addition over the period (1997-2009) we observe significant increase in the share of China in Sudan total imports from all foreign countries of crude materials (that increased from 0.81 in 1997 to $5.16 \%$ in 2009); chemicals (that increased from 3.98\%, in 1997 to $11.35 \%$ in 2009 ); manufactured goods (that increased from $10.27 \%$ in 1997 to $25.72 \%$ in 2009); machinery and equipment (that increased from $14.83 \%$ in 1997 to $28.84 \%$ in 2009); transport equipment (that increased from $7.36 \%$ in 1997 to $12.06 \%$ in 2009) and textiles (that increased from 7\% in 1997 to $47.26 \%$ in 2009). As for the total imports, the share of China in Sudan total imports from all foreign countries are 6.28\%, 13.80\%, 4.56\%, 6.56\%, 10.66\%, 8.03\%, 7.95\%, 13\%, 20.47\%, 20.80\%, 27.76\%, 23.13\%, 19.88\%, $14.16 \%$ and 15.67\% in 1997, 1998, 1999, 2000, 2001, 2002, 2003, 2004, 2005, 2006, 2007, 2008, 2009, 2010 and (2000-2010) respectively. 
Table (11) China - Sudan trade: Exports from Sudan to China by commodities during the period (1997-2010) (value in US\$ 000's)

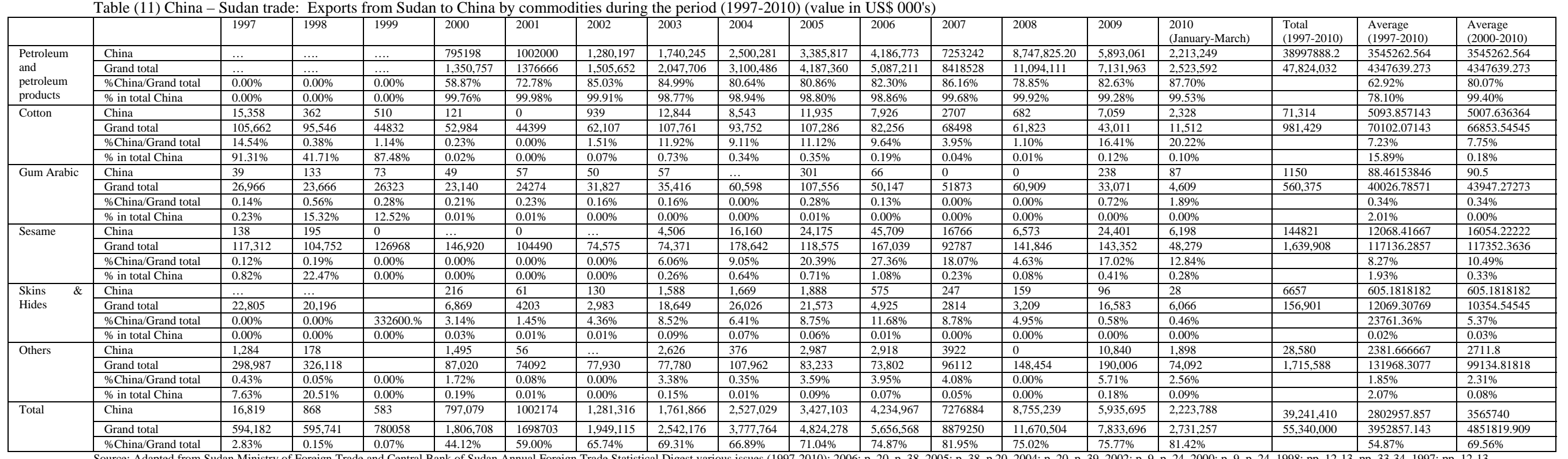

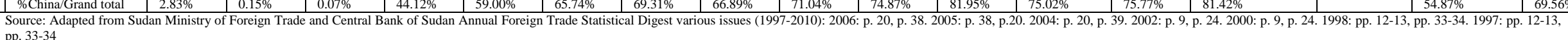


Table (12) Imports to/for Sudan from China by commodities during the period (1997-2010) (value in US\$ 000's)

\begin{tabular}{|c|c|c|c|c|c|c|c|c|c|c|c|c|c|c|c|c|c|c|}
\hline & & 1997 & 1998 & 1999 & 2000 & 2001 & 2002 & 2003 & 2004 & 2005 & 2006 & 2007 & 2008 & 2009 & $\begin{array}{l}2010 \\
\text { (January-March) }\end{array}$ & $\begin{array}{l}\text { Total } \\
\text { (1997-2010 }\end{array}$ & $\begin{array}{l}\text { Average } \\
(1997-2010)\end{array}$ & $\begin{array}{l}\text { Average } \\
(2000-2010)\end{array}$ \\
\hline \multirow{4}{*}{$\begin{array}{l}\text { Coffee and } \\
\text { Tea }\end{array}$} & China & 407 & 0 & 0 & 4 & 14 & 53 & 40 & 3 & 134 & 70 & 38 & 108 & 85 & & & 73.53846154 & \\
\hline & Grand total & 50,384 & 51,534 & 52904 & 42,615 & 46,709 & 65,801 & 49,412 & 63,263 & 71,651 & 42,509 & 81,152 & 81679 & 160593 & 23011 & 883,217 & 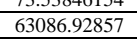 & $\begin{array}{l}66217.72727 \\
\end{array}$ \\
\hline & \%China/Grand total & $0.81 \%$ & $0.00 \%$ & $0.00 \%$ & $0.01 \%$ & $0.16 \%$ & $0.03 \%$ & $0.08 \%$ & $0.08 \%$ & $0.00 \%$ & $0.19 \%$ & $0.05 \%$ & $0.13 \%$ & $0.05 \%$ & $0.00 \%$ & $1.60 \%$ & $0.11 \%$ & $0.07 \%$ \\
\hline & \% in total China & $0.41 \%$ & $0.00 \%$ & $0.00 \%$ & $0.00 \%$ & $0.04 \%$ & $0.01 \%$ & $0.02 \%$ & $0.01 \%$ & $0.00 \%$ & $0.01 \%$ & $0.00 \%$ & $0.00 \%$ & $0.00 \%$ & $0.00 \%$ & $0.51 \%$ & $0.04 \%$ & $0.01 \%$ \\
\hline \multirow{4}{*}{$\begin{array}{l}\text { Wheat and } \\
\text { wheat flour }\end{array}$} & China & 9 & & 0 & & 57 & & 1,114 & 5,516 & 245 & 89 & 0 & 0 & 1 & & 7031 & 703.1 & 877.75 \\
\hline & Grand total & 138,400 & 131,945 & 123333 & 207,942 & 138096 & 221,319 & 200,744 & 257,226 & 383,634 & 341,672 & 363629 & 715,342 & 696,001 & 195471 & $4,114,754$ & 293911 & 338279.6364 \\
\hline & \%China/Grand total & $0.01 \%$ & $0.00 \%$ & $0.00 \%$ & $0.00 \%$ & $0.04 \%$ & $0.00 \%$ & $0.55 \%$ & $2.14 \%$ & $0.06 \%$ & $0.03 \%$ & $0.00 \%$ & $0.00 \%$ & $0.00 \%$ & $0.00 \%$ & $0.00 \%$ & $7353.85 \%$ & $5490.00 \%$ \\
\hline & \% in total China & $0.01 \%$ & $0.00 \%$ & $0.00 \%$ & $0.00 \%$ & $0.03 \%$ & $0.00 \%$ & $0.49 \%$ & $1.04 \%$ & $0.02 \%$ & $0.01 \%$ & $0.00 \%$ & $0.00 \%$ & $0.00 \%$ & $58.86 \%$ & $60.46 \%$ & $4.32 \%$ & $5.50 \%$ \\
\hline \multirow{4}{*}{$\begin{array}{lr}\text { Other } & \text { Food } \\
\text { Stuff } & \end{array}$} & China & 1,319 & 839 & 2288 & 1,802 & 3428 & 4,849 & 6,989 & 13,731 & 14,094 & 18,673 & 20807 & 22,895 & 26,100 & 6,389 & 144,203 & 10300.21429 & 12705.18182 \\
\hline & Grand total & 49,152 & 80,253 & 100008 & 88,965 & 121295 & 172,520 & 170,100 & 195,487 & 363,899 & 332,446 & 377079 & 540,290 & 781,310 & 456,729 & $3,829,533$ & 273538.0714 & 327283.6364 \\
\hline & \%China/Grand total & $2.68 \%$ & $1.05 \%$ & $2.29 \%$ & $2.03 \%$ & $2.83 \%$ & $2.81 \%$ & $4.11 \%$ & $7.02 \%$ & $3.87 \%$ & $5.62 \%$ & $5.52 \%$ & $4.24 \%$ & $3.34 \%$ & $1.40 \%$ & $48.81 \%$ & $3.49 \%$ & $3.89 \%$ \\
\hline & \% in total China & $1.33 \%$ & $0.32 \%$ & $3.55 \%$ & $1.77 \%$ & $2.03 \%$ & $2.47 \%$ & $3.05 \%$ & $2.59 \%$ & $1.02 \%$ & $1.11 \%$ & $0.85 \%$ & $1.06 \%$ & $1.35 \%$ & $1.92 \%$ & $24.43 \%$ & $1.74 \%$ & $1.75 \%$ \\
\hline \multirow{4}{*}{$\begin{array}{l}\text { Beverage and } \\
\text { Tobacco }\end{array}$} & China & 1,670 & 17 & 0 & 23 & 48 & 3 & 107 & 2,439 & 6,007 & 7,373 & 9927 & 8,276 & 7,294 & 1,814 & 44,998 & 3214.142857 & 3937.363636 \\
\hline & Grand total & 32,306 & 20,131 & 19164 & 18,718 & 23664 & 26,496 & 21,956 & 39,939 & 42,545 & 47,684 & 56225 & 53,462 & 69,693 & 16,441 & 488,424 & 34887.42857 & 37893 \\
\hline & \%China/Grand total & $5.17 \%$ & $0.08 \%$ & $0.00 \%$ & $0.12 \%$ & $0.20 \%$ & $0.01 \%$ & $0.49 \%$ & $6.11 \%$ & $14.12 \%$ & $15.46 \%$ & $17.66 \%$ & $15.48 \%$ & $10.47 \%$ & $11.03 \%$ & $96.40 \%$ & $6.89 \%$ & $8.29 \%$ \\
\hline & \% in total China & $1.68 \%$ & $0.01 \%$ & $0.00 \%$ & $0.02 \%$ & $0.03 \%$ & $0.00 \%$ & $0.05 \%$ & $0.46 \%$ & $0.43 \%$ & $0.44 \%$ & $0.41 \%$ & $0.38 \%$ & $0.38 \%$ & $0.55 \%$ & $4.84 \%$ & $0.35 \%$ & $0.29 \%$ \\
\hline \multirow{4}{*}{$\begin{array}{l}\text { Petroleum } \\
\text { Products }\end{array}$} & China & 322 & 2,925 & 11 & 69 & 6 & 98 & 49 & 671 & 1,076 & 1,255 & 957 & 776 & 309 & & $852400.00 \%$ & 608.8571429 & 478.7272727 \\
\hline & Grand total & 292,708 & 255,664 & 184620 & 107,951 & 98149 & 132,254 & 148,712 & 101,434 & 322,006 & $\frac{1,205}{414,182}$ & 291406 & 710,962 & 325,611 & 100,665 & $3,486,324$ & 249023.1429 & 250302.9091 \\
\hline & \%China/Grand total & $0.11 \%$ & $1.14 \%$ & $0.01 \%$ & $0.06 \%$ & $0.01 \%$ & $0.07 \%$ & $0.03 \%$ & $0.66 \%$ & $0.33 \%$ & $0.30 \%$ & $0.33 \%$ & $0.11 \%$ & $0.09 \%$ & $0.00 \%$ & $3.25 \%$ & 0.002324319 & 0.001812769 \\
\hline & \% in total China & $0.32 \%$ & $1.10 \%$ & $0.02 \%$ & $0.07 \%$ & $0.00 \%$ & $0.05 \%$ & $0.02 \%$ & $0.13 \%$ & $0.08 \%$ & $0.07 \%$ & $0.04 \%$ & $0.04 \%$ & $0.02 \%$ & $0.00 \%$ & $1.95 \%$ & 0.001394219 & 0.00046537 \\
\hline \multirow{4}{*}{$\begin{array}{l}\text { Crude } \\
\text { Materials }\end{array}$} & China & 254 & 2,055 & 230 & 59 & 233 & 240 & 893 & 750 & 2,972 & 4,903 & 6076 & 10,867 & 8,243 & 2,582 & $4035700.00 \%$ & 2882.642857 & 3438 \\
\hline & Grand total & 31,426 & 51,802 & 52939 & 28,972 & 10525 & 68,642 & 79,326 & 96389 & 104,477 & 138,179 & 115269 & 154,049 & 159,619 & 41,594 & $1,133,208$ & 80943.42857 & 90640.09091 \\
\hline & \%China/Grand total & $0.81 \%$ & $3.97 \%$ & $0.43 \%$ & $0.20 \%$ & $2.21 \%$ & $0.35 \%$ & $1.13 \%$ & $0.78 \%$ & $2.84 \%$ & $3.55 \%$ & $5.27 \%$ & $7.05 \%$ & $5.16 \%$ & $6.21 \%$ & $39.97 \%$ & $2.85 \%$ & $3.16 \%$ \\
\hline & \% in total China & $0.26 \%$ & $0.77 \%$ & $0.36 \%$ & $0.06 \%$ & $0.14 \%$ & $0.12 \%$ & $0.39 \%$ & $0.14 \%$ & $0.21 \%$ & $0.29 \%$ & $0.25 \%$ & $0.50 \%$ & $0.43 \%$ & $0.78 \%$ & $4.70 \%$ & $0.34 \%$ & $0.30 \%$ \\
\hline \multirow[t]{4}{*}{ Chemicals } & China & 7,565 & 10,948 & 8768 & 9,105 & 9160 & 24,869 & 21,969 & 39,346 & 75,083 & 73,881 & 95936 & 105,380 & 97,582 & 13,326 & 592,918 & 42351.28571 & 51421.54545 \\
\hline & Grand total & 189,891 & 157,025 & 114193 & 221,127 & 123618 & 206,457 & 231,298 & 327,487 & 493,841 & 490,465 & 574628 & 684,517 & 859,531 & 237,757 & $4,911,835$ & 350845.3571 & 404611.4545 \\
\hline & \%China/Grand total & $3.98 \%$ & $6.97 \%$ & $7.68 \%$ & $4.12 \%$ & $7.41 \%$ & $12.05 \%$ & $9.50 \%$ & $12.01 \%$ & $15.20 \%$ & $15.06 \%$ & $16.70 \%$ & $15.39 \%$ & $11.35 \%$ & $5.60 \%$ & $143.03 \%$ & $10.22 \%$ & $11.31 \%$ \\
\hline & \% in total China & $7.63 \%$ & $4.12 \%$ & $13.59 \%$ & $8.94 \%$ & $5.42 \%$ & $12.67 \%$ & $9.59 \%$ & $7.43 \%$ & $5.43 \%$ & $4.40 \%$ & $3.94 \%$ & $4.87 \%$ & $5.06 \%$ & $4.01 \%$ & $97.11 \%$ & $6.94 \%$ & $6.52 \%$ \\
\hline \multirow{4}{*}{$\begin{array}{l}\text { Manufactured } \\
\text { goods }\end{array}$} & China & 30,051 & 156,540 & 20906 & 30,554 & 43720 & 53,901 & 61,720 & 156,437 & 378,372 & 480,471 & 702316 & 660,720 & 640,926 & 118,443 & $3,535,077$ & 252505.5 & 302507.2727 \\
\hline & Grand total & 292,748 & 592,076 & 237342 & 293,724 & 296490 & 555,014 & 728,677 & 996,504 & $1,672,864$ & $1,640,833$ & 1941618 & $1,936,964$ & $2,491,934$ & 489,486 & $14,166,274$ & 1011876.714 & 1185828 \\
\hline & \%China/Grand total & $10.27 \%$ & $26.44 \%$ & $8.81 \%$ & $10.40 \%$ & $14.75 \%$ & $9.71 \%$ & $8.47 \%$ & $15.70 \%$ & $22.62 \%$ & $29.28 \%$ & $36.17 \%$ & $34.11 \%$ & $25.72 \%$ & $24.20 \%$ & $276.65 \%$ & $19.76 \%$ & $21.01 \%$ \\
\hline & \% in total China & $30.31 \%$ & $58.93 \%$ & $32.39 \%$ & $29.98 \%$ & $25.87 \%$ & $27.45 \%$ & $26.94 \%$ & $29.54 \%$ & $27.36 \%$ & $28.61 \%$ & $28.83 \%$ & $30.54 \%$ & $33.26 \%$ & $35.67 \%$ & $445.68 \%$ & $31.83 \%$ & $29.46 \%$ \\
\hline \multirow{4}{*}{$\begin{array}{l}\text { Machinery } \\
\text { and } \\
\text { Equipment }\end{array}$} & China & $\frac{30.01 \%}{40,014}$ & $\frac{30.93 \%}{74,319}$ & $\begin{array}{l}\frac{2.5950}{19994} \\
\end{array}$ & 37,275 & 73212 & 67,9590 & $\frac{20.94 \%}{72,724}$ & $\begin{array}{l}2.5940 \\
164,730 \\
\end{array}$ & $\begin{array}{l}2.0 .0 \% \\
502,334 \\
\end{array}$ & $\begin{array}{l}20.01 \%, 0 \\
716,045 \\
\end{array}$ & $\begin{array}{l}20.05 \% \\
1038176 \\
\end{array}$ & $\begin{array}{l}0.50,40 \\
952,444 \\
\end{array}$ & $\begin{array}{l}3.260 \\
752,445 \\
\end{array}$ & $\begin{array}{l}33.07 \% 0 \\
113,215\end{array}$ & $\begin{array}{l}435.004,917 \\
4,624\end{array}$ & $\begin{array}{l}3.030 \\
330351.2143\end{array}$ & $\begin{array}{l}29.40 \% \\
408235.4545 \\
\end{array}$ \\
\hline & Grand total & 269,748 & 348,151 & 358786 & 323,517 & 442537 & 620,807 & 717,922 & $1,080,653$ & $1,971,883$ & $2,810,535$ & 3195408 & $3,058,942$ & $2,609,227$ & 590,391 & $18,398,507$ & 1314179.071 & 1583802 \\
\hline & \%China/Grand total & $14.83 \%$ & $21.35 \%$ & $5.57 \%$ & $11.52 \%$ & $16.54 \%$ & $10.95 \%$ & $10.13 \%$ & $15.24 \%$ & $25.47 \%$ & $25.48 \%$ & $32.49 \%$ & $31.14 \%$ & $28.84 \%$ & $19.18 \%$ & $268.72 \%$ & $19.19 \%$ & $20.63 \%$ \\
\hline & \% in total China & $40.36 \%$ & $27.98 \%$ & $30.98 \%$ & $36.58 \%$ & $43.31 \%$ & $34.63 \%$ & $31.75 \%$ & $31.11 \%$ & $36.32 \%$ & $42.64 \%$ & $42.61 \%$ & $44.03 \%$ & $39.05 \%$ & $34.09 \%$ & $515.44 \%$ & $36.82 \%$ & $37.83 \%$ \\
\hline \multirow{4}{*}{$\begin{array}{l}\text { Transport } \\
\text { Equipment }\end{array}$} & China & 12,743 & 13,142 & 9379 & 15,629 & 19201 & 21,003 & 39,801 & 74,749 & 286,049 & 220,310 & 392090 & 232,030 & 232,361 & 42,856 & $1,611,343$ & 115095.9286 & 143279.9091 \\
\hline & Grand total & 173,182 & 192,735 & 132205 & 158,683 & 202879 & 255,832 & 409,080 & 739,342 & $1,149,739$ & $1,490,544$ & 1463122 & $1,115,573$ & $1,195,507$ & 251,592 & $8,930,015$ & 637858.2143 & 766535.7273 \\
\hline & \%China/Grand total & $7.36 \%$ & $6.82 \%$ & $7.09 \%$ & $\begin{array}{l}.85 \% \\
9.85 \%\end{array}$ & $9.46 \%$ & $8.21 \%$ & $9.73 \%$ & $10.11 \%$ & $\begin{array}{l}1,143,130 \\
2.88 \%\end{array}$ & $14.78 \%$ & $26.80 \%$ & $10.73 \%$ & $12.06 \%$ & $12.91 \%$ & $170.78 \%$ & $12.20 \%$ & $13.59 \%$ \\
\hline & $\%$ in total China & $12.85 \%$ & $4.95 \%$ & $14.53 \%$ & $15.34 \%$ & $11.36 \%$ & $10.70 \%$ & $17.37 \%$ & $14.11 \%$ & $20.68 \%$ & $13.12 \%$ & $16.09 \%$ & $10.73 \%$ & $12.06 \%$ & $12.91 \%$ & $186.79 \%$ & $13.34 \%$ & $14.04 \%$ \\
\hline \multirow{4}{*}{ Textiles } & China & 4,197 & 4,834 & 2962 & 7,381 & 16165 & 23,265 & 23,682 & 71,162 & 116,754 & 156,282 & 169879 & 169,786 & 161,590 & 30,701 & 958,640 & 68474.28571 & 86058.81818 \\
\hline & Grand total & 59,955 & 38,469 & 39455 & 60,524 & 85706 & 140,334 & 124,688 & 1774,968 & 233,669 & 295,307 & 315921 & 299,760 & 341,892 & 140,603 & $2,351,251$ & 167946.5 & 201215.6364 \\
\hline & \%China/Grand total & $7.00 \%$ & $12.57 \%$ & $7.51 \%$ & $12.20 \%$ & $18.86 \%$ & $16.58 \%$ & $18.99 \%$ & $40.67 \%$ & $49.97 \%$ & $52.92 \%$ & $53.77 \%$ & $56.64 \%$ & $47.26 \%$ & $21.84 \%$ & $416.78 \%$ & $29.77 \%$ & $35.43 \%$ \\
\hline & \% in total China & $4.23 \%$ & $1.82 \%$ & $4.59 \%$ & $7.24 \%$ & $9.56 \%$ & $11.85 \%$ & $10.34 \%$ & $13.44 \%$ & $8.44 \%$ & $9.31 \%$ & $6.97 \%$ & $7.85 \%$ & $8.39 \%$ & $9.25 \%$ & $113.27 \%$ & $8.09 \%$ & $9.33 \%$ \\
\hline \multirow[t]{3}{*}{ Total } & China & 99,146 & 265,619 & 64538 & 101,901 & 169029 & 196,332 & 229,088 & 529584 & $1,382,989$ & $1,679,416$ & 2436202 & $2,163,282$ & $1,926,936$ & 332,075 & $11,576,137$ & 826866.9286 & 1013348.545 \\
\hline & Grand total & $1,579,716$ & $1,924,649$ & 1414949 & $1,552,738$ & 1585465 & $2,446,384$ & $2,881,915$ & $4,075,230$ & $6,756,820$ & $8,073,498$ & 8775457 & $9,351,540$ & $9,690,918$ & $2,344,866$ & $62,454,145$ & 4461010.357 & 5230439.182 \\
\hline & \%China/Grand total & $6.28 \%$ & $13.80 \%$ & $4.56 \%$ & $6.56 \%$ & $10.66 \%$ & $8.03 \%$ & $7.95 \%$ & $13.00 \%$ & $20.47 \%$ & $20.80 \%$ & $27.76 \%$ & $23.13 \%$ & $19.88 \%$ & $14.16 \%$ & $197.05 \%$ & $14.07 \%$ & \begin{tabular}{|l}
$15.67 \%$ \\
\end{tabular} \\
\hline
\end{tabular}




\section{2. 3. China investment in oil sector in Sudan and China-Sudan aid relationships}

The significant investment of China in oil sector in Sudan motivated China to increase its aid and development assistance to Sudan economy over the period (1997-2009). For instance, Table 13 explains that the share of China in total loans and grants offered to Sudan show a declining trend over the period (1999-2004), the share of China in total foreign aid (loans and grants) to Sudan declined from 17\% in 1999 to 0\%, 0\%, 7\%, 8\% and 7\% in 2000, 2001, 2002, 2003 and 2004 respectively. But the share of China in total foreign aid (loans and grants) to Sudan dramatically and rapidly increased to $76 \%$ in 2005 , the share declined once again to $24 \%$ in 2006 but it increased again to $73 \%$ in 2007 and it is declined to 3.35\% in 2008 and then increased to $27.44 \%$ in 2009. One possible explanation of this changing trend is that the rapid increase in the share of China in total foreign aid (loans and grants) to Sudan in 2005 and 2007, is probably attributed to China's consistent policy to increase cooperation and involvement of China in Africa rich oil countries by increasing aid, investment and trade with African rich oil countries including Sudan. Moreover, another interpretation is that the implementation of peace agreement accord in 2005, probably have encouraged China to increase her involvement in offering aid and development assistance to Sudan. Another justification is the increase of China involvement in oil sector in Sudan. On the other hand, the declining trend in 2006 probably due to the policy of China government to reduce her development assistance and aid to developing and African countries, including Sudan, another interpretation is probably due to general decline in Chinese grant to Sudan from 36\% in 2005 to $14 \%$ in 2006, the year which witnessed rapid increase in the share of grants in total foreign aid offered by all foreign donors to Sudan from 0.3\% in 2005 to 19\% in 2006. The great decline over the period (2007-2009) is probably related to the global economic and financial crisis which leads to drop in the inflow of foreign resources from foreign donors. These findings implies the high and significant share of Chinese aid and development assistance to Sudan compared to the international aid and development assistance from other countries transmitted to Sudan economy over the period (1997-2009). We observe the rising share and significance of the Chinese aid and development assistance to Sudan from 33\% to 45\% and 58\% during the periods (2002-2007), (2004-2007) and (2005-2007) respectively- see Table 13 below. These findings are consistent with the stylized facts which indicate the rising share and significance but irregular and considerable fluctuation in the Chinese aid and development assistance to Africa, particularly; Africa rich oil countries over the period (1999-2007).

The results of Nour (2009) indicate the effectiveness and significant contribution of China in the implementation of several development projects and imply that the increase in the inflow of Chinese aid and development assistance in the form of loans has caused mixed positive and negative impacts for Sudan economy over the period (1997-2007). On the one hand, it has some positive impacts by providing alternative complementary sources of finance to complement the shortage of domestic capital and financing development projects, on the other hand, it has a 
negative impact by increasing Sudan external obligations and debts to China and by increasing Sudan total external obligations and debts and by offering tied aid and hence, undermining the effectiveness of Chinese aid to Sudan. For instance, Nour (2009) finds that the increasing inflow of Chinese aid lead to increase in the share of China in Sudan's total debt from 0.9\% in 1999 to 13.45\% in 2007. The main reason behind this negative impact of increasing Sudan's debts to China is probably due to the nature of the composition of Chinese aid. For instance, the share of total grants and technical and commodity aid (5\%) is less than the share of total loans (95\%). This composition implies that the majority of Chinese aid offered to Sudan (1990-2008) was in the form of commercial loans (87\%) that have caused the negative impact by increasing debt, which is offered with petroleum guarantees and with interest rate which caused an increase in the debt problem in Sudan as in many other developing countries. In addition, the Chinese aid to Sudan is tied/ related to trade, FDI and importance of oil to Chinese economy. Despite the global financial and economic crisis but China has reaffirmed its commitment to fulfill earlier commitments and to maintain further aid and development assistance to Sudan, China is expected to continue commitment to a win-win policy and is likely to continue offering tied aid to Sudan to maintain strategic economic opportunities and interests of its engagement in Sudan and its access to oil.

\begin{tabular}{|c|c|c|c|c|c|c|c|c|c|c|c|}
\hline & 1999 & 2000 & 2001 & 2002 & 2003 & 2004 & 2005 & 2006 & 2007 & 2008 & 2009 \\
\hline China Total grants & 1200 & 0 & 0 & 0 & 0 & 3,6 & 1,2 & 19,5 & 0 & 0 & 0 \\
\hline China Total loans and grants & 13200 & 0 & 0 & 50,7 & 10 & 18,4 & 815,2 & 174,7 & 1104921672 & 22.20 & 202.24 \\
\hline$\%$ of Chinese loan & $91 \%$ & 0 & 0 & $100 \%$ & $100 \%$ & $80 \%$ & $99.1 \%$ & $89 \%$ & $100 \%$ & $100 \%$ & $100 \%$ \\
\hline Grand Total loans & 76104 & & & 691,17 & 114,35 & 243,2 & 1072,5 & 589,5 & 1491113704 & 436.8 & 507.60 \\
\hline Grand Total grants & 1200 & & & 9,83 & 17,42 & 6,72 & 3,3 & 138,2 & 15635358,55 & 225.48 & 229.5 \\
\hline Grand Total loans and grants & 77304 & & & 701 & 131,77 & 249,92 & 1075,8 & 727,6 & 1506749063 & 662.28 & 737.10 \\
\hline$\%$ of China in total loans & $16 \%$ & $0 \%$ & $0 \%$ & $7 \%$ & $9 \%$ & $6 \%$ & $76 \%$ & $26 \%$ & $74 \%$ & $5.08 \%$ & $39.84 \%$ \\
\hline$\%$ of China in total grants & $100 \%$ & $0 \%$ & $0 \%$ & $0 \%$ & $0 \%$ & $54 \%$ & $36 \%$ & $14 \%$ & $0 \%$ & 0 & 0 \\
\hline$\%$ of China in total loans and grants & $17 \%$ & $0 \%$ & $0 \%$ & $7 \%$ & $8 \%$ & $7 \%$ & $76 \%$ & $24 \%$ & $73 \%$ & $3.35 \%$ & $27.44 \%$ \\
\hline $\begin{array}{l}\text { \% of China in total loans and grants (1999- } \\
\text { 2007) }(2007-2009)^{(1)}\end{array}$ & $24 \%$ & $24 \%$ & $28 \%$ & $33 \%$ & $38 \%$ & $45 \%$ & $58 \%$ & $49 \%$ & $73 \%$ & $38 \%$ & $35 \%$ \\
\hline
\end{tabular}

Sources: Adapted from the Central Bank of Sudan Annual Reports (1999-2007), Ministry of International Cooperation and Ministry of Finance and National Economy.

Note: (1) For calculation of the average share of China in total loans and grants (1999-2007) and (2007-2009) we use the year 2007 as a reference year because it witnessed the Note: (1) For calculation of the average share of China in total loans and grants (1999-2007)
largest inflow of China aid and development assistance to Sudan over the period (1999-2009).

\section{3. Overview on the oil impacts, opportunities and challenges for development in Sudan}

Based on the above overview on the importance and historical background about the structure, exploration and production of oil in Sudan, since the structure of Sudan economy is now related to oil, so it will be useful to explain the impact of oil in Sudan economy in the this section. Notably, to examine if oil has affected the general socio- economic characteristics presented in the section 2 above. So it is now useful in this section to explain the oil economy in Sudan by explaining the various positive and negative impacts of oil in Sudan economy and the opportunities and challenges for development in Sudan. It would be useful to begin with the positive impacts of oil and opportunities for development in the Sudan and then explain the negative impacts of oil and challenges of development in Sudan- see Table 14 below. 
Table 14- the impacts of oil in Sudan economy and macroeconomic indicators in Sudan (1999-2010)

\begin{tabular}{|c|c|c|c|c|c|c|c|c|c|c|c|c|}
\hline & 1999 & 2000 & 2001 & 2002 & 2003 & 2004 & 2005 & 2006 & 2007 & 2008 & 2009 & 2010 \\
\hline Revenue (\% of GDP) & $8 \%$ & $11.5 \%$ & $10.7 \%$ & $11.9 \%$ & $16.0 \%$ & $19.7 \%$ & $21.7 \%$ & $20.0 \%$ & $19.9 \%$ & $19.3 \%$ & $13.5 \%$ & \\
\hline Expenditure (\% of GDP) & $8.9 \%$ & $12.2 \%$ & $11.6 \%$ & $12.8 \%$ & $15.3 \%$ & $18.2 \%$ & $23.4 \%$ & $24.3 \%$ & $23.0 \%$ & $17.8 \%$ & $16.3 \%$ & \\
\hline Fiscal Deficit (\% of GDP) & $-0.9 \%$ & $-0.7 \%$ & $-0.9 \%$ & $-0.8 \%$ & $1 \%$ & $1.5 \%$ & $-1.8 \%$ & $-4.3 \%$ & $-3.1 \%$ & $1.6 \%$ & $-2.8 \%$ & \\
\hline Oil exports (\% of GDP) & $1 \%$ & $9.5 \%$ & $10 \%$ & $10 \%$ & $12 \%$ & $14 \%$ & $15 \%$ & $14 \%$ & $18 \%$ & $7.3 \%$ & $7.2 \%$ & \\
\hline Total oil export & $689 \%$ & $1,350,757$ & $1,376,666$ & $1,510,857$ & $2,047,705$ & $3,100.5$ & $4,187.4$ & $5,087.2$ & $8,418.5$ & $11,094.1$ & $7,131.20$ & $2,523,592$ \\
\hline Total non oil export & 1,164 & 455.9 & 322 & 438.3 & 4949.5 & 677.3 & 636.9 & 569.4 & 460.7 & 576.4 & 702.5 & 207,665 \\
\hline Total exports & 1,853 & 1806.7 & 1698.7 & 1949.1 & 2542.2 & $3,777.8$ & $4,824.3$ & $5,656.6$ & $8,879.2$ & $11,670.5$ & $7,833.70$ & $2,731,257$ \\
\hline Total imports & 1256.2 & 1553 & 1457 & 2179.22 & 2536.1 & 3586.18 & $5,946.0$ & $7,104.0$ & $7,722.4$ & $8,229.4$ & $8,528.0$ & $2,344,866$ \\
\hline Trade deficit & -476.1 & 254 & 90 & -230.11 & 6.07 & 191.57 & -1121.7 & $-1,448.1$ & $1,156.8$ & $3,441.1$ & -694.3 & 386,391 \\
\hline Balance of payment deficit & 111.5 & 81.5 & -90.04 & 198.72 & 422.6 & 730.2 & 530.5 & -208.6 & -282 & 21.1 & -502.2 & \\
\hline \% oil exports & $37 \%$ & $74.8 \%$ & $81 \%$ & $77.5 \%$ & $80.6 \%$ & $82.1 \%$ & $87 \%$ & & & $95.1 \%$ & $91.0 \%$ & \\
\hline$\%$ non oil export & $63 \%$ & $25.2 \%$ & $19 \%$ & $22.5 \%$ & $19.4 \%$ & $17.9 \%$ & $13 \%$ & & & $4.9 \%$ & $9.0 \%$ & \\
\hline Total revenue & 109015 & 334.0 & 366.3 & 474.9 & 715.0 & 1029.0 & 1218.4 & 15075 & $18,462.4$ & $24,707.9$ & $20,045.6$ & \\
\hline Total oil revenues & 15.7 & 143.8 & 149.7 & 200.6 & 399.0 & 502.9 & 608.6 & 7557 & $10,047.6$ & $15,996.7$ & $9,596.2$ & \\
\hline Total non oil revenues & 108999.3 & 190.2 & 216.6 & 274.3 & 316.0 & 526.1 & 609.8 & 7518 & 8414.8 & $8,711.20$ & $10,449.4$ & \\
\hline Share of oil in total revenues (\%) & $0.01 \%$ & $43 \%$ & $41 \%$ & $42.3 \%$ & $40 \%$ & $49 \%$ & $50 \%$ & $50 \%$ & $54.4 \%$ & $64.7 \%$ & $47.9 \%$ & \\
\hline Share of non-oil in total revenues (\%) & 99.09 & $57 \%$ & $59 \%$ & $57.7 \%$ & $60 \%$ & $51 \%$ & $50 \%$ & $50 \%$ & $45.6 \%$ & $35.3 \%$ & $52.1 \%$ & \\
\hline Oil share in GDP (\%) & $1 \%$ & $6.8 \%$ & $7.9 \%$ & $9.1 \%$ & $9.6 \%$ & $14.6 \%$ & $15.1 \%$ & $15.1 \%$ & $20.1 \%$ & $18.2 \%$ & & \\
\hline Oil revenues share GDP (\%) & & $4.6 \%$ & $4.3 \%$ & $5.1 \%$ & $8.8 \%$ & $9.5 \%$ & $9.9 \%$ & & & & & \\
\hline Current spending\% in total spending & & $85 \%$ & $81.8 \%$ & $73 \%$ & $74.9 \%$ & $71.9 \%$ & $78.5 \%$ & $80.61 \%$ & $82.99 \%$ & $87.45 \%$ & $85.29 \%$ & \\
\hline $\begin{array}{l}\text { Development spending (\%) in total } \\
\text { spending }\end{array}$ & & $15 \%$ & $18.2 \%$ & $27 \%$ & $25.1 \%$ & $28.1 \%$ & $21.5 \%$ & $19.39 \%$ & $17.01 \%$ & $12.55 \%$ & $14.71 \%$ & \\
\hline Current spending\% in GDP & & $9.70 \%$ & $9.90 \%$ & $10.60 \%$ & $12.00 \%$ & $15.10 \%$ & $18.10 \%$ & & & & & \\
\hline Development spending (\%) in GDP & & $1.7 \%$ & $2.2 \%$ & $2.6 \%$ & $4 \%$ & $5.8 \%$ & $4.5 \%$ & $6.4 \%$ & $7.2 \%$ & $7.4 \%$ & & \\
\hline Total spending \% in GDP & & $11.4 \%$ & $12.1 \%$ & $13.2 \%$ & $16 \%$ & $20.9 \%$ & $22.6 \%$ & & & & & \\
\hline Net FDI MUS\% & & 392 & 574 & 713.2 & 1349.2 & 1511.1 & 2304 & 35341 & 24256 & & & \\
\hline Foreign resources MUS\$ & & 132.2 & 401.2 & 607.4 & 263.7 & 853.8 & 1310.5 & & & & & \\
\hline
\end{tabular}

Sources: Adapted from the Central Bank of Sudan and Ministry of Finance and National Economy Annual Reports (Various Issues)

\section{3. 1. Oil and the opportunities for development in the Sudan}

To explain the opportunities for development, it would be useful to explain the various positive impacts of oil in Sudan economy, this includes the impacts of oil in satisfying domestic demand and achievement of self sufficiency, the impact of oil in increasing government resources as measured by the share of Sudan government in oil revenues from partnership with foreign oil producing companies in Sudan. In addition to the impacts of oil on Sudan's economic growth as measured by the growth in the GDP and its composition or structure, the impacts of oil on the public government budget as measured by the government revenues and government spending. In addition to the impacts of oil on foreign trade as measured by the volume and structure of exports, the impacts of oil in the balance of trade and balance of payment. In addition to the impact of oil on foreign direct investment (FDI), the impacts of oil in improving Sudan's relationship with external regional and international financial institutions and finally the impacts of oil in improving social development in Sudan.

Beginning with the impact of local oil production, we find that one important positive impact and opportunity created by oil is that the local production and availability of oil enable Sudan to have a self sufficiency in oil to satisfy the domestic demand. In addition, the local production of oil enables the government to cancel the high bill that was equivalent to at least or even more than US\$300- US\$375 million that was previously allocated for the importation of oil to satisfy the local demand. ${ }^{32}$ Moreover, when Sudan stopped importing oil and oil products, it has a surplus amount of capital that was previously allocated in the government budget to oil import, this enables the government to mobilize the saving of these surplus resources to be used or allocated to fund other domestic needs. Furthermore, the local production of oil with surplus amount that leads to exportation of oil implies that Sudan has turned from an oil importing

\footnotetext{
${ }^{32}$ See Salih, (2004), p.166.
} 
economy into an oil exporting economy- see Figures 7-8 below. For instance, in 2001; local oil consumption represented about $49 \%$ of total local oil production which implies that the oil exports represented about $51 \%$ of total local oil production. ${ }^{33}$ Oil Exports is estimated to be $275,000 \mathrm{bbl} /$ day in 2004 . More than $50 \%$ of the Sudanese crude oil is exported, with $40 \%$ shipped to China. In 2004, oil imports were reported at 0 bbl/day. Sudanese domestic oil consumption is estimated to be averaged $82,000 \mathrm{bbl} / \mathrm{d}$ in 2005. This was a 15 percent increase over the 70,000 bbl/d consumed during 2004. Sudan's crude oil exports have increased sharply since the completion of a major oil-export pipeline in 1999. Return from oil exports to Sudan is US\$ 500 million and US\$ 600 million in 2000 and 2001 respectively. ${ }^{34}$

Figures 7- Sudan`s Oil Production and Consumption 1980-2005

Sudan's Oil Production and Consumption, 1980-2005

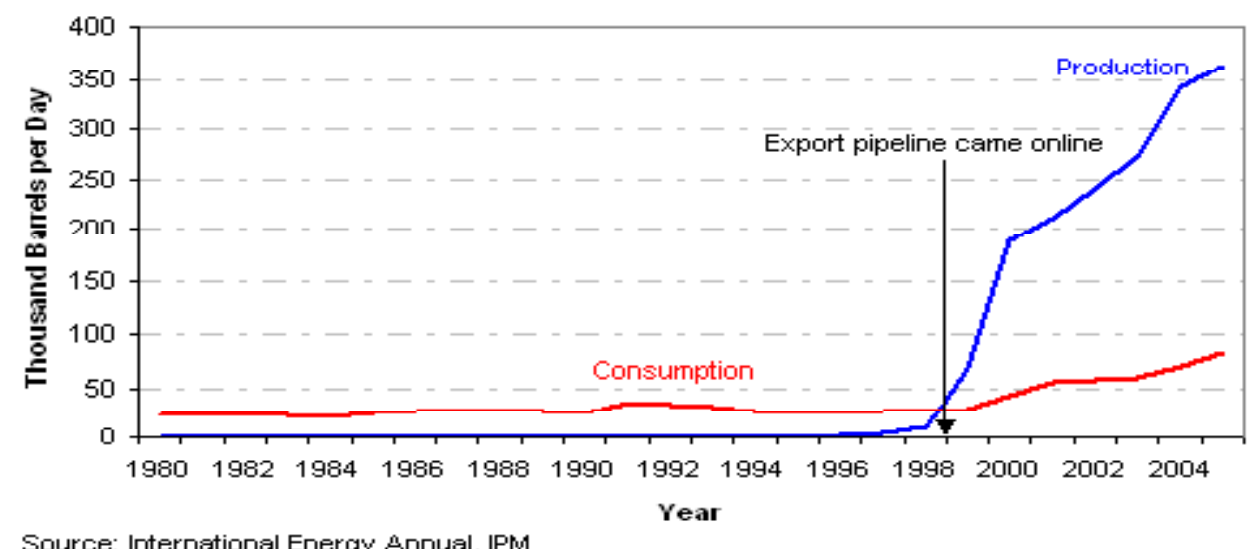

Figures 8- Sudan‘s Oil Production and Consumption 1990-2008

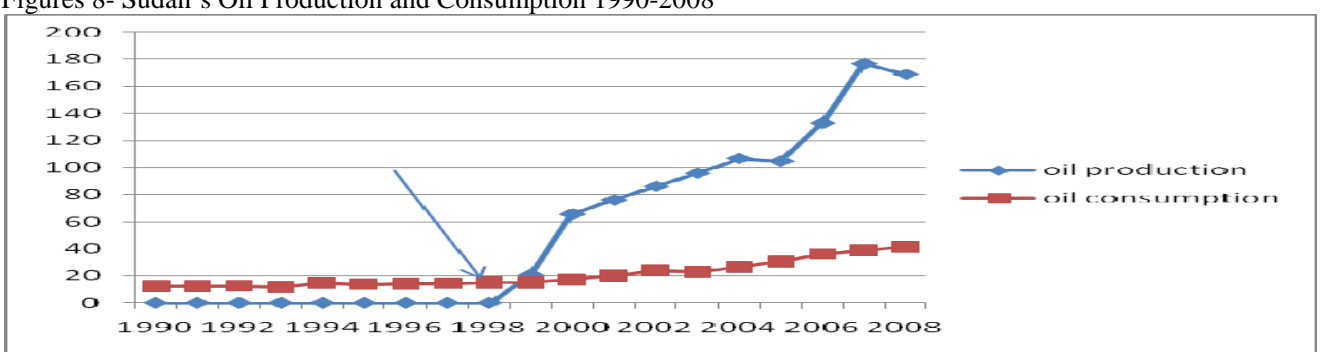

Source: Adapted from Sudan Ministry of Energy and Mining Statistics

As for the impact of oil on government resources, we observe the positive impact of oil on offering additional financial resources for the Sudan government and this can be perceived from the increasing share of Sudan government in oil revenues from partnership with foreign oil producing companies in Sudan. For instance, oil production started in the second half of 1999 with the capacity of 150000 barrel per day, the average production for 2002 was 2350000 barrel per day which implies an increase of about $56 \%$ in three years, with annual growth rate of $18 \%$, the total output or production from September 1999 and until the end of 2003 estimated at about 240 million barrel, the share of Sudan government in oil revenues from partnership with foreign

\footnotetext{
${ }^{33}$ See Salih, (2004), p. 94.

${ }^{34}$ See Salih, (2004), p. 91.
} 
oil producing companies in Sudan over the period (1999-2002) was on average 45\% of total oil revenues, whereas about $40 \%$ of total oil revenues was allocated for covering the costs of investment and about $15 \%$ of total oil revenues was allocated as profit for oil producing and investors companies. ${ }^{35}$ The share of Sudan government in total oil production and hence revenues continuously and rapidly increased from about $23 \%$ in 2000 to about $42 \%, 60 \%, 65 \%$, 71\% and 75\% in the years 2001, 2002, 2003, 2004 and 2005 respectively. ${ }^{36}$ The distribution of revenues implies that oil revenue was at least 20 percent of government income. ${ }^{37}$ Oil revenues also enable Sudan government to cover half of the total cost equivalent to US\$ 640 million for the establishment of Khartoum refinery which is established in (50\%:50\%) partnership basis between Sudan government and China (GNPC). ${ }^{38}$ It is important to note that the share of government in total oil revenues is influenced by the interaction of two factors, the first factors is the output effect that related to the quantity of total product, as the government share increases with the increase of total production and declines with the decline in total production. The second factor is the price effect related to the international prices of oil in the international market, notably, the increase in the international prices of oil has positive impacts mainly by reducing the total production cost evaluated per barrel and generating an additional revenues to the government and therefore, leads to increase in the share of government and the vice-versa. The impact of the first output effect is obvious from the increase in the quantity of production and hence, the share of government during the period 1997-2008, since the share of government increased from 25\% in 1999 to $75 \%$ in 2005, but the share declined in 2009 due to the outweigh negative effect of the second factor. The impacts of the second factor or price effect on the share of government is noticeable from the recent impacts of the change or fluctuation in international oil prices, for instance, before 2009, the significant growth in the share of government is positively affected by the rise of oil prices that witnessed continuous increase until it reached the highest price registered in the international market equivalent to US\$140 bbl/day in the mid of 2008. But on the other hand, the rapid turn and great decline in oil in the first quarter of 2009 due to decline in demand due to global financial and economic crisis has a negative effect and led to decline in oil revenues and hence the share of Sudan government declined to $56.7 \%$ in 2009 due to decline in the international prices in the international market. ${ }^{39}$

As for the impact of oil on foreign trade as measured by the volume and structure of exports, the impacts of oil in the balance of trade and balance of payment, we find that oil has positive impact on the balance of trade and balance of payment as the chronic deficit in the balance of trade and the balance of payment since independence turned into a surplus for the first

\footnotetext{
${ }^{35}$ See Salih, (2004), p. 182.

${ }^{36}$ See Ministry of Finance and National Economy (2006) “The Performance of Sudan Economy 2000-2005” April, 2006, pp: 16-18

${ }^{37}$ See Sudan Factsheet Human Rights \& Oil workshop-January 31, 2003, p. 2.

${ }^{38}$ See Salih, (2004), p, 93.

${ }^{39}$ See Ilaf Newspaper (2009) "How Oil affected the composition and structure of Sudan Economy? And what are the Consequences," fifth year, Issue No. 239 Wednesday September 9, 2009, p.5. Khartoum, Sudan, 2009.
} 
time after the exportation of oil. For instance, the balance of payment registered a surplus for the first time in the years 2001, 2004, 2007 and 2008. But this surplus in the balance of payment seem to be un-sustained as it is immediately turned and changed into a deficit most probably due to the increase in imports of capital goods. As for the balance of trade, the chronic deficit in the trade balance reached its maximum in 1998, as the deficit estimated at about US\$1136.5 million. Mainly, the import of capital equipment for the production of oil has great impact on causing this deficit. But after beginning of oil exports the balance of trade deficit turned into surplus. Notably, oil exports and the average share of oil that represents about 95\% from the total exports lead to positive impact and improvement in the balance of trade over the period 2000-2009. For instance, the balance of trade registered considerable surplus in the years 2000, 2003, 2004, 2007 and 2008 and it reached its maximum in 2008, as the balance of trade registered a surplus equivalent to about US $\$ 4018$ million, and the average contribution of oil in the balance of trade is equivalent to about US\$1900 million in 2008. ${ }^{40}$ Sudan's real growth of trade of 25 percent in 2007 represents the second highest growth in the world for that year among all countries. This is a substantial increase from the already high historical trade growth rates since the oil export boom. While total exports grew dramatically from 7 percent of GDP in 1996 to 14 percent in 2006, imports remained higher at 16 period of GDP and led to a trade deficit averaging two percent of GDP since 1999. The oil export boom raised the value of total exports from US\$620 million in 1996 to US\$4,522 million (1996 prices) in 2006, representing more than 700 percent increase over the decade. But the rise in the costs of investment in oil due to begin of production from other oil fields and the import of further equipment in this field once again has led to deficit in the trade balance in 2002, but the deficit in 2002 was not caused by a decline in oil export revenues but rather was caused by the increase in import value (capital equipment). The large import demand of the country, the huge transportation and other expenses related to oil operation, and the moderate performance of the non-oil exports contributed to the current account deficit. The magnitude of current account and balance of payments during 1999-2006 however were smaller compared to pre-oil exportation levels. ${ }^{41}$

Moreover, as for the impacts of oil on gross domestic product (GDP), we observe that oil lead to significant positive impacts on GDP and structural change in the structure of Sudan economy and macroeconomic indicators of the national economy as measured by the share of oil in the GDP and its growth rate and the composition of GDP. For instance, we observe the increasing impact of oil as measured by the share or contribution of oil on in the GDP, as the contribution of oil sector started by the share of $1 \%$ in the year 1999 and it continuously increased to reach $10 \%$ in GDP in the year 2004. We find that the impact of oil in Sudan economy is perceived from the fact that oil lead to great improve in the growth of GDP, for

\footnotetext{
${ }^{40}$ See Ilaf Newspaper (2009) "How Oil affected the composition and structure of Sudan Economy? And what are the Consequences,"
} fifth year, Issue No. 239 Wednesday September 9, 2009, p.5. Khartoum, Sudan, 2009. 
instance, the average rate of growth of GDP increased from 6.2\% over the period 1997-1999 to 6.8\% over the period 2000-2009 and to 9.6\% over the period 2006-2008. In 2005, Sudan's real GDP has grown of 8 percent according to the IMF. In 2006, Oil production helped to sustain the current state of Sudan's economy to a growth rate of $10 \%$ from the previous year. Oil leads to impressive real growth, as the real GDP growth averaged about 9 percent during 2005-2007, putting Sudan among the fastest growing economies in the region; Figure 9 shows that Sudan is a top growth performer in the region, with oil playing a pivotal role - see Figure 9 below. $^{42}$

Figure 9 - Average Real GDP Growth Rate in Sudan compared to other African countries during the period (2003-2006)

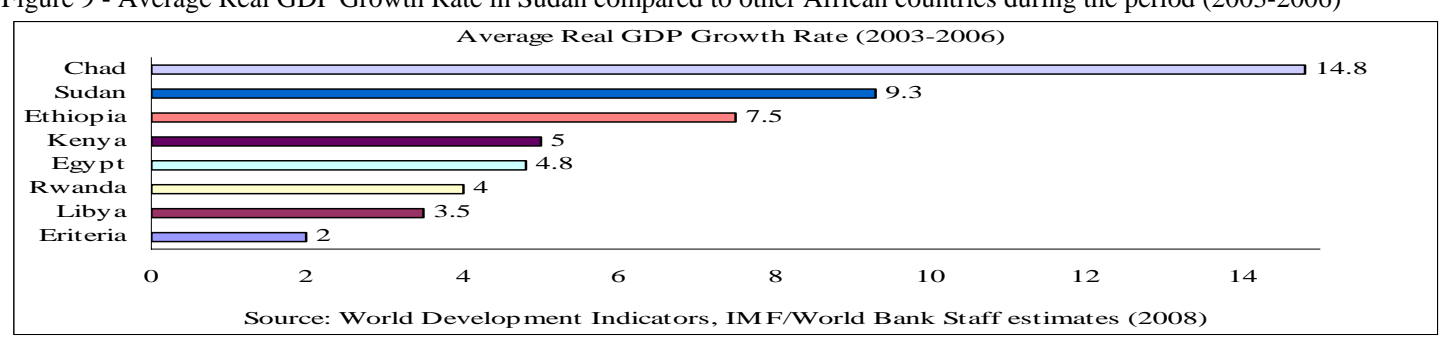

Source: The World Development Indicators (WDI)/ IMF/World Bank Staff Estimate (2008)

Moreover, the composition of GDP witnessed great structural change over the same time period. The dividends from oil exportation have caused major transformations in the economy, especially in the country's capital. Figure 10-11 summarizes the recent structural changes. The structure of the Sudanese economy has shifted over time, from predominantly reliant on agriculture for growth and exports, to its current reliance on the oil sector. At independence, the structure of the economy was dual with a vast traditional sector based on agriculture and a small modern sector mainly consisting of the transport, communication, real estate and construction services. The contribution of agriculture to the country's growth diminished over the past decades. Agriculture's contribution to GDP has declined, and to a lesser extent industry as well. Wide fluctuations were observed during the 1980s and 1990s, with episodes of contraction during the time of conflict and drought and resurgence during 1986, 1989, 1992 and 1996 with growth exceeding ten percent. ${ }^{43}$

Figure 10- Structural Change in Sudan Economy (1996-2007)

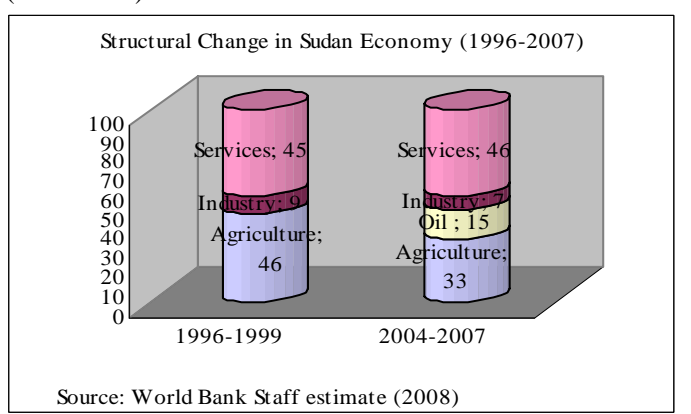

Figure 11- Contribution of Oil and Non-Oil Sectors to GDP Growth in Sudan (2003-2007)

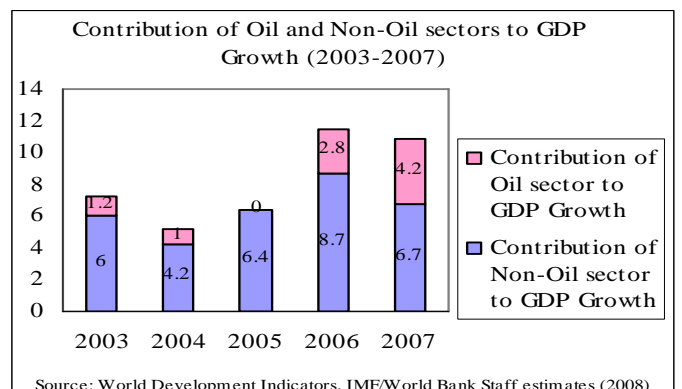

Source: The World Development Indicators (WDI)/ IMF/World Bank Staff Estimate (2008)

\footnotetext{
${ }^{41}$ See WB-DTIS, (2008), p. 7.

${ }^{42}$ See WB-DTIS, (2008), pp. 1-2. See also Oil fact sheet on Sudan, September 2006 p. 1.

${ }^{43}$ See WB-DTIS, (2008), pp. 2-3.
} 
Notwithstanding these structural shifts, agriculture remains the country's main driver of employment, especially outside the country's top urban areas of Khartoum and Port Sudan. ${ }^{44}$ Near to $35 \%$ of Sudan's GDP comes from Agricultural production which employs $80 \%$ of the workforce, but the difficult environmental conditions coupled with political instability has allowed for some troubled times for Sudan's economy in the agricultural sector. ${ }^{45}$ For a typically oil economy, the impact of oil in the economy is often expected to extend to help improvement and growth in other productive and services sectors. But for the case of Sudan, while oil lead to positive impacts on the performance of Sudan economy as it lead to positive and high increase in the national economy that on average estimated at about $9.8 \%$, but it is worthy to mention that the analysis of the high increase in the rate of growth is attributed only to oil sector while the impacts of oil on other productive non-oil sectors such as agriculture, industry and services remained to be very limited. The evidence for this appears from the composition or the share of different sectors in the GDP. For instance, due to increasing share of oil in GDP, consequently, the contribution of industrial sector (which includes oil, quarrying and mining, manufacturing, electricity and water and construction) in GDP increased to about 32.3\% in 2008 compared to about $21.7 \%$ over the period 1999-2004. While the contribution of both the agricultural sector and the services sectors declined, which clearly indicate the weak and limited impacts of oil on the other sectors in Sudan economy including the agricultural and services sectors over the short run, but over the long run these sectors may benefit from the impacts and the continuous increase in oil sector. Currently, the limited extended impact of oil is limited to only three branches of the services sector. For example, the oil sector has led recent growth, both in terms of direct valueadded to the economy as well as the associated investment boom and boost to services such as transportation and construction. The emergence of the oil sector adds directly to GDP and has induced growth in certain services sectors. Construction services grew by about 10 percent per annum since 1999 and have been the fastest growing sector in recent years, surpassing the growth in the oil industry. Trade, restaurants and hotels have also flourished, mainly in the country's capital, and generated about one fifth of non-oil domestic product during 1996-2006. With forecasts pointing to oil sector production peaking in the near term, the economic policy dialogue is turning to the need for balanced growth and strengthening the non-oil sectors which are key for sustainable growth and addressing inequalities.

Moreover, as for the impacts of oil in the public government budget, we find that oil has positive impact in the public finance and budget as it leads to significant increase in the total government public revenues and total government public spending. For instance, on the side of revenues, we observe the fluctuating growth in the share of oil revenues over the period 19972009 despite the continuous increase in the quantity of total production that was caused by the

\footnotetext{
${ }^{44}$ See WB-DTIS, (2008), pp. 1-3.
} 
fluctuation in the share of government from the total production probably due to fluctuation in international prices as we mentioned above. The impact of oil in public budget can be perceived from the contribution of oil revenues in total revenues over the period 1999-2009. For instance, we observe the large and increasing share of oil revenues in total revenues since 2000 and until 2008, although the period 1999-2003 has witnessed reasonable increase in the share of non-oil revenues in the total revenues, but the period 2006-2008 witnessed a great increase in the share and contribution of oil revenues in total revenues, as the share and contribution of oil in total revenues increased from about $43 \%$ in 2000 to about 50\% in 2006 and to about $66 \%$ in 2008 . Despite the continuous government efforts to increase the share of non-oil revenues in total revenues and to fund the government expenditure, the share of oil revenues in total revenues remain significant as its share is estimated to be $50 \%$ over the period $1999-2004$, but this share is significantly declined to $34 \%$ in 2009 , most probably due to the impacts of the global economic and financial crisis. Therefore, this implies the urgent need to avoid heavy dependence on oil revenues. On the other hand on the side of the impacts of oil on the government expenditure or public spending: we find that the production and export of oil has direct impact on increasing the share of oil in public spending, we observe that the development spending also increased by noticeable amount as its share in public expenditures increased from about $21 \%$ over the period 1996-1999 to about 24\% on average over the period 2000-2004. But despite the increase in development expenditure from public expenditure from 9\% in 1999 to around 31\% in 2004 its share declined and sustained at 24\% from the total public spending over the period 2006-2009. The government indicates its efforts to direct large part of oil revenues to development spending as it assumed direction of benefit for future generations; it strongly maintains that oil revenues are earmarked for development projects and infrastructural development. ${ }^{46}$

Moreover, as for the impact of oil on improvement of Foreign Direct Investment (FDI) inflow to Sudan, we find that oil also has positive impact and motivated the increase in the FDI inflow to Sudan. The implementation of economic reform policies, liberalization and privatization in the late 1990s, together with the exploitation of oil in 1999 and issue of investment encouragement act of 2003, which stated the non discrimination between national and foreign capital and investment have all created favorable conditions for business environment and encouraged private national and foreign investment and led to the high and increasing inflow of FDI to Sudan- see Table 2 above. In particular, the exploitation of oil in 1999 encouraged the inflow of FDI. For instance, according to Arab Human Development Report (2003) data on the estimated net FDI flows, by host country in the Arab region over the period (2000-2001) indicates that the estimated net FDI flow to Sudan show an increasing trend over the period (2000-2001), from US\$ 392 million in 2000 to US\$ 574 million in 2001. In 
addition the rank of Sudan among Arab countries has improved from occupying the fourth place after Egypt, Algeria and Tunisia in 2000, to occupying the third place after Morocco and Algeria in $2001 .{ }^{47}$ In addition we find that over the past years, Sudan witnessed inflow of foreign direct investment for the different productive sectors. For instance, the volume of investment increased over the period 1996-2004 from US\$251.3 to US\$ 1381 million, which implies that the rate of growth is near to about 500\%. This includes the sectors of energy and mining, agriculture, services and industry, as the estimated average share of each of these sectors on total investment was estimated at about $74.7 \%, 8.6 \%, 7.6 \%$, and $9.1 \%$ respectively. This implies that the large share of FDI investment was concentrated on the energy and mining sector and this attributed to the increasing investment in oil. Despite the huge export earnings from oil, the current account balance has been in deficit at eight percent of GDP on average during 1999-2005. This is partly induced by increased imports of manufactured, machinery and transport equipments and other commodities. The impact of these expenses in the overall balance of payments is subdued by the influx of foreign direct investment (FDI). In 2004 and 2005, the influx of FDI led to overall surplus in the balance of payments. Moreover, in 2006, the levels of foreign direct investment (FDI) in Sudan were among Africa's highest with over US\$3.5 billion, stimulated by the signing of the CPA and encouraged by policy reforms, favourable energy and crop prices, rising urban consumption, and macroeconomic stability. From annual averages of US\$100-200 million prior to 2000, in 2006 net FDI and portfolio inflows were US\$3.5 billion, though tailing off to US\$3 billion in 2007. The increase in FDI has been encouraged by the liquidity in the Gulf. International reserves are low and falling; from 2.4 months of imports at end 2005 to 1 month at end of 2007, and Sudan's external debt remains large and arrears constrain access to longer-term development finance. ${ }^{48}$ Sudan Net FDI also registered a sharp drop by some US\$ 500 million already by June 2008, partly due to the completion of several major infrastructure projects, as well as net private transfers, mainly remittances, falling by close to US\$ 800 million compared with 2006. ${ }^{49}$ For 2009 however, due to the global shock resulting in lower global oil prices, stagnating domestic oil production and related reduction in government spending the annual growth rate is estimated to slow down to 3.9 percent. ${ }^{50,51}$ The global financial crisis is expected to further reduce both categories by another $30-36 \%{ }^{52}$ The distribution of FDI for the economic sector is as follows energy (73\%); economic services sector (15\%); industrial sector (10\%) and

\footnotetext{
${ }^{46}$ See Sudan Factsheet Human Rights \& Oil workshop-January 31, 2003, p. 2.

${ }^{47}$ See the World Investment Report (2002) UNCTAD. See also Arab Human Development Report (2003): Table 5.1 p.102.

${ }^{48}$ See WB-DTIS, (2008), p. 4.

${ }^{49}$ See the IMF First Review of Performance Under the 2007-08 Staff-Monitored Program, June 2008, p.6.

${ }^{50}$ See the World Bank Sudan Economic Brief April 2009.

${ }^{51}$ See the International Monetary Fund, World Economic Outlook Database, April 2009, www.imf.org .

52 See the IMF Report on "the Implications of the Global Financial Crisis for Low-Income Countries," March 2009, p.48: http://www.imf.org/external/pubs/ft/books/2009/globalfin/globalfin.pdf.
} 
agricultural sector (2\%). ${ }^{53}$ This implies that oil enables Sudan to be emerged as one of the highest recipients of foreign direct investment in Africa and Arab regions.

Moreover, as for the impact of oil on improvement of Sudan relation with foreign international financial institutions, we find that the exploitation, production and exportation of oil enables Sudan to use oil revenues to repay back part of its debt to donors in international financial institutions. For example the oil revenues improved the ability of Sudan's average monthly repayment from US\$ 65 million over the period 1996-1998 to US\$ 300 million over the period 1999-2009. Oil also encourages improvement on the inflow of foreign resources to Sudan from US\$ 150 million dollars in 1990s to about US\$ 550 million dollars over the period 20012009. On the other hands the impact of oil in the Sudan economy can be perceived in terms of reducing the risk that can be realized from the great increase in the inflow of foreign investment and aid; improve the relationship with the international financial institutions; regular repay of Sudan's obligations towards donors that probably reduce the risk for the external donors and enables Sudan to get further loans and grants that contributed to fulfillment of development projects such as Merowe dam and other electricity and transport projects, etc.. ${ }^{54}$

Moreover, as for the impact of oil on improvement of social services in Sudan, we find that the positive impact of oil on improvement in social services can be perceived from the fact that oil revenues provides additional resources available for improving the social services, notably, the achievement of economic stability and inflow of foreign investment has contributed to social development. For instance, the national government and the national and foreign companies working in oil producing and transporting areas contribute to improvement of social services and development programmes which contributed to enhancement of stability of population living in these areas. This includes improvement of health services that represented by the establishment of hospitals and health or medical centers and buying of medical equipment and establishment of medical laboratory; improvement of availability of water services and that represented by the establishment of water stations. In addition to improvement of education services which is represented by the establishment of primary basic and secondary schools, improvement in basic infrastructure such as building of bridges and road network and planning of cities and improvement of agricultural and animal veterinary services. In addition to creation of employment opportunities as earlier the agriculture and animal husbandry were considered to be the only activities in oil producing areas -except some commercial activities-, this caused limitation in employment opportunities in oil exploration areas and also caused the migration of some of the population to look for better conditions. But the discovery of oil and increasing attention in offering social services in these areas led to improvement in employment

\footnotetext{
${ }^{53}$ See Sudan Ministry of Finance and National Economy (2002) “the Sudan Economy in Figure,” Ministry of Finance and National Economy, Macroeconomic Policies and Programme Directorate MEPPD, First Edition, (2002), p 27.

${ }^{54}$ See Ilaf Newspaper (2009) "How Oil affected the composition and structure of Sudan Economy? And what are the Consequences," fifth year, Issue No. 239 Wednesday September 9, 2009, p.5. Khartoum, Sudan, 2009.
} 
opportunities in these areas. Despite the lack of accurate statistics in increase in availability of employment opportunities created in these areas, but it is observed that the oil areas turned into attractive and development areas compared to other non-oil areas. As oil exploration and production activities attracted a large amount and transfer of domestic and foreign capital that motivated flourishing of trade and commercial activities and creation of more economic activities and employment opportunities that motivated and contributed to stability of population living in these areas. This implies that oil has contributed to expansion of physical and social infrastructure including a doubling of the road network and electricity generation in Sudan. Oil also has potential impact on socio-economic development in Sudan as oil revenue contributed to total revenue that can be directed to support social and economic development in Sudan. ${ }^{55}$

Furthermore, as for the impacts of oil in the labour market, we find that oil has slight effect in the labour market because the exploration and production of oil leads to creation of more employment opportunities -although difficult to elaborate due to lack of accurate recent data. For instance, of total labour force estimated at 9,7000,000 in 2001, the share and contribution of oil industries in total employment is very minimal and accounted for only $0.0087 \%$ of total employment of labour force in Sudan (2001) and only $0.52 \%$ of total employment in the industrial manufacturing sector in Sudan (2001). It is worthy to note that the contribution of oil industries represent only $0.52 \%$ of total employment and $0.64 \%$ of total number of labour employed in the industrial manufacturing sector in Sudan (2001) but in the meantime oil industries is ranked second in terms of the contribution to industrial value added as it accounts for $11 \%$ of total industrial value added in the manufacturing industries in Sudan, this implies that oil industries tend to use more capital intensive techniques and to be a more capital intensive industry. For instance, in the three oil establishments included in the comprehensive industrial survey (2005), the total employment was 846 and the total labour was 845 (of which production workers were 830 and non production workers were 15) in 2001. ${ }^{56}$ Moreover, other impact of oil in the labour market is that the inflow of FDI and the increased wealth from oil has encouraged migration to the Sudan. Consequently, migrant workers have increased in the labour market, particularly in the private sector, which may also affect the structure of labour market and contribute to the growing unemployment rate. Furthermore, oil also affected the structure of wages and lead to wage differential in Sudan, for instance, the results of the comprehensive industrial survey (2005), indicates that the highest compensation for workers in the industrial

\footnotetext{
55 See Ilaf Newspaper (2009) "How Oil affected the composition and structure of Sudan Economy? And what are the Consequences," fifth year, Issue No. 239 Wednesday September 9, 2009, p.5. Khartoum, Sudan, 2009. See also Salih, (2004), pp. 117-118.

${ }^{56}$ See for instance, Sudan central bureau of statistics Statistical Year Book (2001), Khartoum, November 2003 for the data on the total number of labor force in Sudan in 2001.See for instance, the Sudan Ministry of Industry (2005) the Comprehensive Industrial Survey data for (2001) (Tables 12- 13: the industrial survey pp.72-75) for the data on total number and share of oil in total employment and in employment in the industrial manufacturing sector in Sudan in 2001.
} 
sector is reported in the petroleum refining industry which is 18 times more than the average compensation in the industry in $2001 .^{57}$

Finally, as for the impacts of oil in enhancing capacity building, we are aware of the fact that it may be interesting and useful to depart from the analysis of general standardize approach of examining only the macroeconomic impacts of oil, and to use a more in-depth analysis to extend our analysis to focus more explicit on whether the production and export of oil (natural resource-based exports) affected the capacity building including education, training, S\&T and $R \& D$ infrastructure and the growth and development trajectory of Sudan economy. But due to practical problems related to availability of adequate and reliable recent data, unfortunately it will not be possible to discuss this issue in detail in this paper. Furthermore, we believe that most probably the impacts of oil in capacity building including education, training, S\&T and R\&D infrastructure might be still very limited in view of the very recent start of production and exports of oil just before eleven years in 1999. Moreover, although oil leads to increase in public spending and increase in the share of development expenditure as a percentage of total public expenditure from 9\% in 1999 to around 31\% in 2004 but its share declined and sustained at 24\% from the total public spending over the period 2006-2009. Furthermore, the development expenditures include all public spending in development issues including public spending on education, health, etc. Therefore, this implies that it is not at all clear and it is somewhat problematic to distinguish the share and growth of spending on education, training and $R \& D$ that mainly attributed to production and export of oil, but it is important to realize that at the macro level the share of spending on education and R\&D as a percentage of GDP, most probably remained almost the same without reporting a significant change in the pre and post oil periods. In addition, also due to practical problems related to availability of adequate and reliable data unfortunately it will not be possible to give an in-depth analysis of the private spending on education, training and $R \& D$ or the impact of oil companies on training and $R \& D$ at the micro level. So, we hope to cover these issues in our future studies when adequate and reliable data are available and hence, we limit our analysis to the very limited information related to these issues. For instance, we find that the significant China investment in oil sector in Sudan has motivated China to increase technical support for capacity building in Sudan, though the available information implies that direct allocation of Chinese aid to training and education sector is very limited. For instance, in addition to direct internal and external training to improve capacity building in Merowe dam, Chinese company "Harbin-Jilin" offered a grant equivalent to US\$ 10 million to support Merowe technological faculty in June 2008. Moreover, China offers Sudan with four different kinds of technical assistance in the form of scholarships. For instance, over the period (1999-2009), the numbers of Chinese scholarships offered to post graduate Sudanese students to study in China are : 1, 3, 10, 8, 9, 11, 20, 14, 42 and 76 in 1999, 2000, 2001, 2002,

\footnotetext{
${ }^{57}$ See the Executive Summary of the Sudan Comprehensive Industrial Survey, (2005), p. 29.
} 
2003, 2004, 2008, 2009, (1999-2004) and (1999-2009) respectively. The distribution of these scholarships over the period (1999-2004) implies that few (9\%) were offered in the period (19992000), whereas, majority (91\%) were offered in the period (2001-2004), this implies that Chinese scholarships to Sudanese students increased rapidly from 9\% in the period (1999-2000) to (91\%) in the period (2001-2004). The distribution of these scholarships implies that over the period (1999-2004) the majority was offered for Ph.D. degree students (81\%) and few was offered for M.Sc. degree students (19\%). Notably, the majority (93\%) was offered for specialization fields of Engineering (40\%), Science and related fields (53\%) and finally few was offered for fields of specialization in Arts, Social Science and related fields (7\%)- see Table 15 below. $^{58}$

Table 15- Distribution and fields of specialization of Chinese postgraduate scholarships offered to Sudanese (1999-2009)
\begin{tabular}{|l|l|l|l|l|l|}
\hline (a) Fields of specialization (1999-2004) & Total & Share (\%) & (b) Degree (1999-2004) & Total & Share (\%) \\
\hline Engineering & 17 & $40 \%$ & M.Sc. & 8 & $19 \%$ \\
\hline Science and related fields & 22 & $53 \%$ & Ph.D. & 34 & $81 \%$ \\
\hline Engineering, science and related fields & 39 & $93 \%$ & Total (1999-2004) & 42 & $100 \%$ \\
\hline Arts, social science and related fields & 3 & $7 \%$ & Total (1999-2009) & 76 & \\
\hline Total & 42 & $100 \%$ & & & \\
\hline
\end{tabular}

Source: Sudan Ministry of Higher Education and Scientific Research ${ }^{59}$

\section{3. 2 Oil and the challenges of development in the Sudan}

After explaining the positive impacts of oil and the opportunities for development in the Sudan it would be useful to elucidate also the negative impacts of oil and the challenges of development in Sudan. These include the high uncertainty, volatility and risk of dependence on highly fluctuating oil prices in the international market, un-sustained oil revenues, the lack of diversification, the Dutch disease and the challenge of potential future north-south conflict.

The first challenge related with oil is that the real economic activity is currently high, but the lack of economic diversification raises concerns over longer terms sources of growth and sustained development, therefore, the revitalizing non-oil exports is relevant for national priorities. In the early 1960s, Sudan's non-oil exports were roughly one-sixth of gross domestic product; after four decades this ratio has come down to one-fiftieth. Sudan historically enjoyed success in exporting a wide range of products, including cotton, various oilseeds, gum Arabic, livestock, and other products whose exports were significant from time to time, such as sorghum and sugar. Many had earned a global reputation for high quality. But over time traditional exports became stagnant, and Sudan lost market share in several key commodities for which it had been a global leader, such as gum Arabic and sesame. In addition, exports remain concentrated in a handful of countries: for example, sheep are shipped almost exclusively to Saudi Arabia, cotton to Egypt, and sesame oil to Saudi Arabia and the United Arab Emirates. Sudan has experienced a revival in its exports, but this is largely due to the export of oil. Since 1999 the exploitation of oil resources has led to large increases in national wealth, but it has also

\footnotetext{
${ }^{58}$ See unpublished information from Sudan Ministry of Higher Education and Scientific Research (2009)

59 Science and related fields include Science, Geophysics, Math, Physics, System, Geography, Chemistry, Botany, Genetic, Agriculture, Geochemistry, Animal Production, Geology and Public health. Arts, social science and related fields include, Chinese Language, Economics and African and Asian Studies.
} 
complicated macroeconomic management with recent pressures toward internal and external imbalances, as well as a heightened concern for balanced growth in the non-oil sectors which are important for sustainable growth and addressing inequalities in Sudan On the external side, the current account has deteriorated since the oil boom and the real exchange rate has appreciated significantly. The latter has added to competitiveness concerns for non-oil exports, on top of the more fundamental supply-side constraints to production. Therefore, the major challenge created by oil is the need for diversification, although oil has driven the recent surge in real economic growth, but to sustain growth and provide broader income opportunities, Sudan will need to pursue a strategy of diversifying its sources of growth, including enhancing its non-oil exports (e.g. traditional agricultural exports that have provided export earnings over the past half century). So, revitalizing non-oil exports can play an important role in achieving Sudan's tremendous potential for international integration, sustaining and broad-based economic development and promoting widely-shared improvements in living standards. ${ }^{60}$

Another challenge is that oil earnings enter the economy predominantly through public finance channels, yielding significant volatility for fiscal policy. The expansion in public sector expenditures has crowded out private credit and stressed the financial sector. Oil export earnings now support the majority of public finance (55 percent in 2007) and expose fiscal policy to the volatilities of domestic production and international price fluctuations. Significant oil revenue volatility and shortfalls were observed in late 2006 and early 2007 resulting in the highest fiscal deficits since the macro stabilization of the early 1990s-4.3 percent of GDP in 2006 and an estimated 3.1 percent of GDP in 2007, on a cash basis- see Figures 12-13 below. The volatility in revenue has greatly complicated public expenditure management. The monthly volatilities in inflows tend to disrupt capital budgeting most severely, as cash balances are used for immediate recurrent costs, the effects are particularly exaggerated by CPA related spending pressures. ${ }^{61}$ Moreover, there is a considerable decline in revenue from 24,707.9 million Sudanese pounds in 2008 to 20,045.6 million Sudanese pounds in 2009, by the rate of $18.9 \%$, this attributed to the great decline in the share of oil in total revenues that declined by about $40.0 \%{ }^{62}$

Figure 12-13- Sudan’s Fiscal Position has Deteriorated, While Oil Earnings Have Grown, Oil exports and fiscal deficit (\% of GDP)

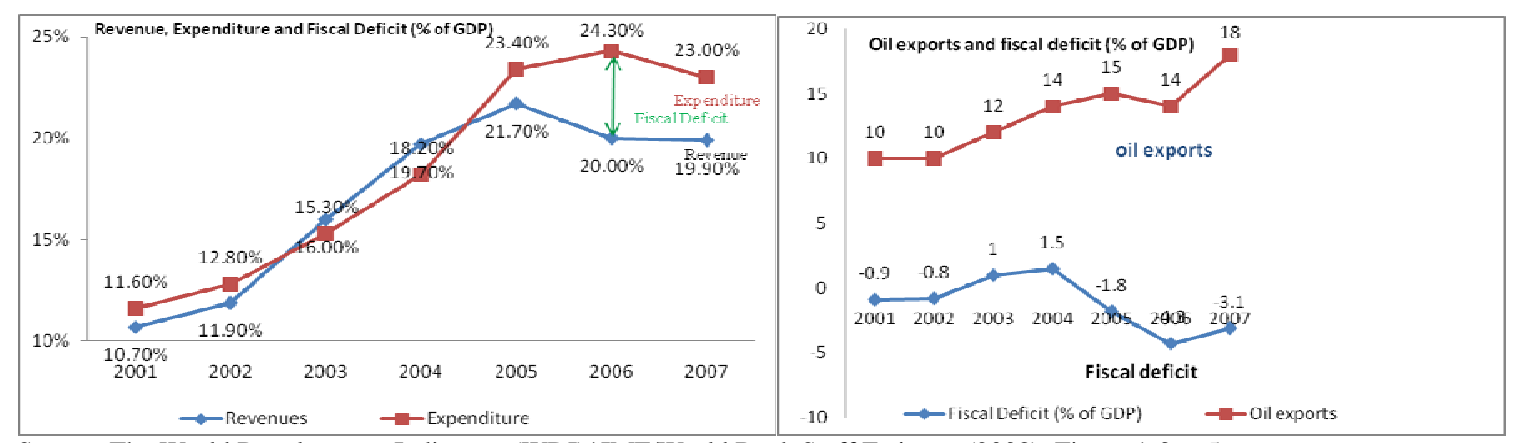

Source: The World Development Indicators (WDI)/ IMF/World Bank Staff Estimate (2008): Figure 1-3, p.5.

\footnotetext{
${ }^{60}$ See WB-DTIS, (2008), p. viii.

${ }^{61}$ See WB-DTIS, (2008), pp. 4-6.
} 
One important challenge created by oil is the weak effect of oil in improving social development indicators. Despite the high oil revenues and the impressive real growth, but so far they are not fully utilized to prioritize the improvement of social development indicators. For instance, from the composition of the public spending, we find that the share of development spending to total public spending witnessed significant increase in the total public expenditure and in the total budget. But despite the increase in development expenditure from public expenditure from $9 \%$ in 1999 to around 31\% in 2004 its share declined and sustained at 24\% from the total public spending over the period 2006-2009. The share of development spending from oil revenues declined from 58\% in 2006 to 34\% in 2008, while the share of current spending from oil revenues increased from $42 \%$ in 2006 to $66 \%$ in $2008 .{ }^{63}$ This clearly indicates the biased and deficiency in the use of oil resources on current spending instead of development spending, and this was probably caused by the use of the current spending to fulfill the requirements of the peace accords and agreements. Consequently, despite the high oil revenues and the impressive real growth emerging vulnerabilities can be seen from both poverty and regional inequalities which are still serious problems in Sudan. For instance, Sudan remains among the world's poorer countries, ranking 147 out of 177 countries based on UNDP's 2007 Human Development Index. The recent household survey data shows that poverty in Sudan is widespread and deep, and the level of inequality is high. ${ }^{64}$ The disparities in health and human development are also remarkable across rural-urban space and gender. The low standard of economic development of the country yields a number of urgent challenges and concerns, and relevance to the development agenda. First the high oil revenues and the impressive real growth must be fully utilized to prioritize the improvement of social development indicators and this also implies the urgent need for revising the current structure and composition to increase the share of development spending relative to current spending from oil revenues. Second the development of the agricultural sector must be supported given the large population base dependent upon it. Third the spatial imbalance in the distribution of natural resources underscores the importance of oil revenue management and redistributive mechanisms for equitable sharing of gains from oil exports. This includes decisions for federal public investment, improvements in the execution of sub-national transfers and basic service delivery. ${ }^{65}$

Another challenge related to oil is the potential incidence of the Dutch disease. For instance, the exploitation of oil resources has led the increase in national wealth, but domestic absorption of these large inflows significantly complicates macroeconomic management. ${ }^{66}$

\footnotetext{
${ }^{62}$ See the Central Bank of Sudan Annual Report (2009), p. 84.

${ }^{63}$ See Sudan Ministry of Finance and National Economy (2002) “the Sudan Economy in Figure,” Ministry of Finance and National Economy, Macroeconomic Policies and Programme Directorate MEPPD, First Edition, (2002), p 27.

${ }^{64}$ The Sudan Household Health Survey (SHHS) was completed in 2006. This is the first household survey covering the whole of Sudan in two decades.

${ }^{65}$ See WB-DTIS, (2008), p.6.

${ }^{66}$ Dutch Disease refers to the experience of the Netherlands in the 1960s, when the economic boom following natural gas discoveries led a decline in manufacturing and real exchange rate appreciation. In his summary of the literature, Corden defines it as a
} 
There is increasing debate on the potential incidence of the Dutch disease in Sudan economy. On the one hand, the views in support of the potential incidence of the Dutch disease is based on the argument that the appreciation of the nominal effective exchange rate and the sustained increases in the general price levels led to the appreciation of real effective exchange in the recent years. This argument indicates that the inflows through higher levels of government spending put additional pressures on the prices of non-traded goods. Prices of housing, water and electricity grew almost twice as fast as the prices of tradable goods specifically food, clothing and consumer goods. The real effective exchange rate appreciated by 40 percent in 2005-2006, which added to the more fundamental structural rigidities and supply-side constraints already faced by non-oil exporters. This argument indicates that some signs of Dutch Disease are present, though it is difficult to assess the extent of these characteristics given the country is a relatively new exporter. ${ }^{67}$ On the other hand, the views in suspecting of the incidence of the Dutch disease is based on the argument that agriculture and services sector continues to dominate the economy even after the increasing share of oil in GDP over the period (1990-2009), moreover, the rise in the share of industry in GDP is mainly attributed to the rise of the share of oil in GDP, while the share of manufacturing in GDP over the period (1999-2006) remained stagnant and the growth rate of manufacturing remained between $1 \%$ and $3 \%$. This argument implies that may be it is too early to say is there any Dutch Disease in Sudan economy. ${ }^{68}$

Figure 14 - The trend of the share of oil exports and non oil exports in total exports and real effective exchange rate in Sudan (19972006)

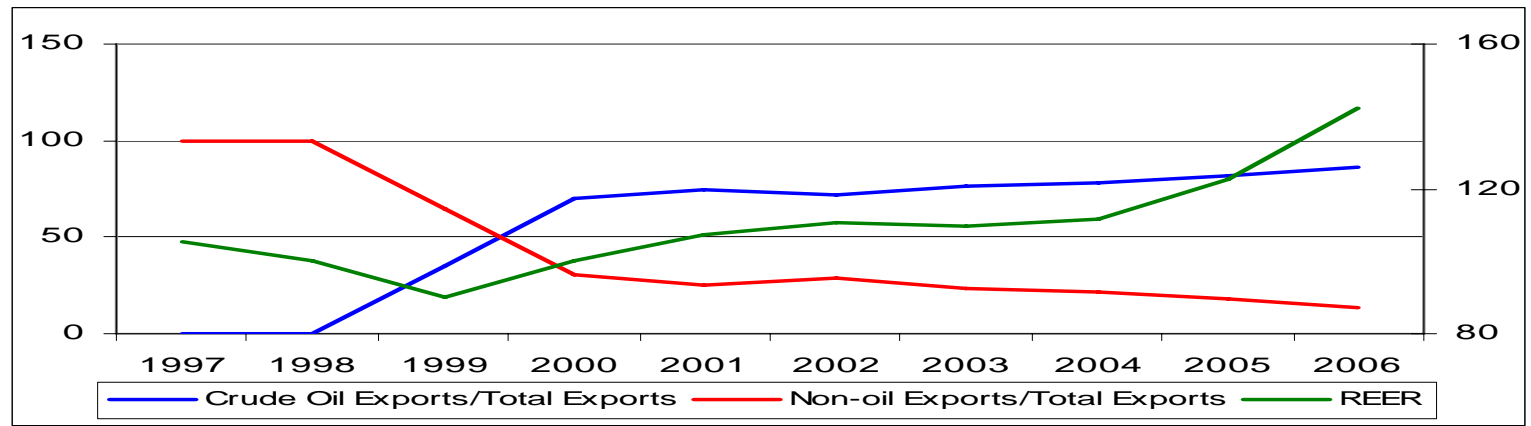

Source: Elbadawi, I. A. and Kaltani L. $(2007)^{69}$

phenomenon where a boom in one export sector, typically a windfall discovery of a new natural resource, draws factors of production from other sectors of the economy and boosts demand for non-tradeables relative to tradeables, which in turn appreciates the real exchange rate. Traditional exports collapse, due both to the internal reallocation of resources and the real exchange rate appreciation. W.M. Corden, “Booming Sector and Dutch Disease Economics: Survey and Consolidation,” Oxford Economic Papers 36 (November 1984): 360-62.

${ }^{67}$ See WB-DTIS, (2008) p. 3. See also Elbadawi, I. A. and Kaltani L. (2007) “The Macroeconomics of Oil Booms: Lessons for SSA” Development Economics Research Group, Economists’ Forum, April 19, 2007. Paper presented at the Ministry of Finance and National Economy and the World Bank “Macroeconomic and Fiscal Federalism Workshop” 14 - 31 July, 2007, Khartoum, Sudan.

68 See Bedawi, W. F. (2007) “A Brief Look At Sudan’s Major Economic Trends and Development Challenges,” Paper presented at the Ministry of Finance and National Economy and the World Bank "Macroeconomic and Fiscal Federalism Workshop” 14 - 31 July, 2007, Khartoum, Sudan.

${ }^{69}$ Elbadawi, I. A. and Kaltani L. (2007) “The Macroeconomics of Oil Booms: Lessons for SSA” Development Economics Research Group, Economists’ Forum, April 19, 2007. Paper presented at the Ministry of Finance and National Economy and the World Bank “Macroeconomic and Fiscal Federalism Workshop” 14 - 31 July, 2007, Khartoum, Sudan. 
Figure 15- Where is the Dutch Disease? Agriculture and Services continue to dominate the economy 2006 GDP by sectors at factor cost

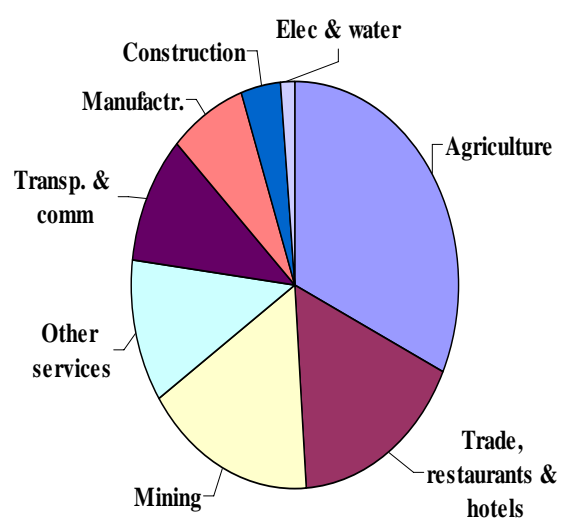

Source: Bedawi, W. F. $(2007)^{70}$
Figure 16- May be too early to say is there any Dutch Disease? Measured by the GDP sectoral growth rate over the period (1999-2006)

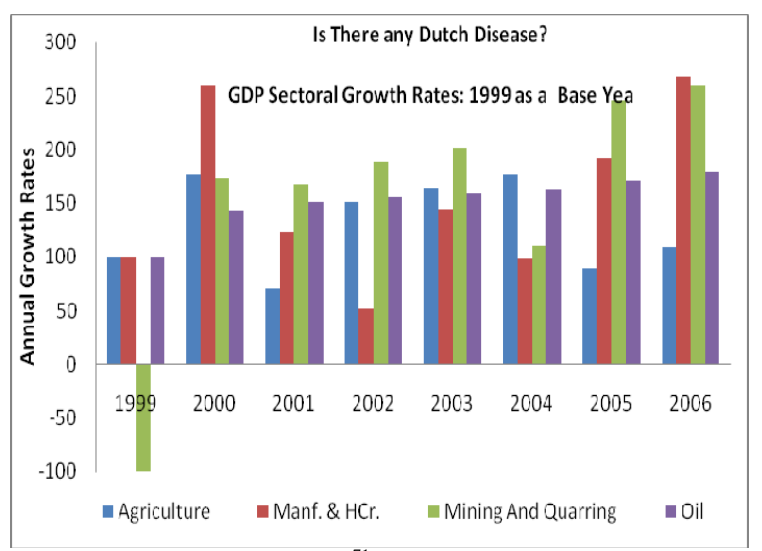

Source: Bedawi, W. F. $(2007)^{71}$

Figures 17-20- Structure of Sudan Economy: Share of sectors in GDP, share of sectors in employment and annual sectoral growth rate (share of sectors in GDP) (1990-2009) (\%)

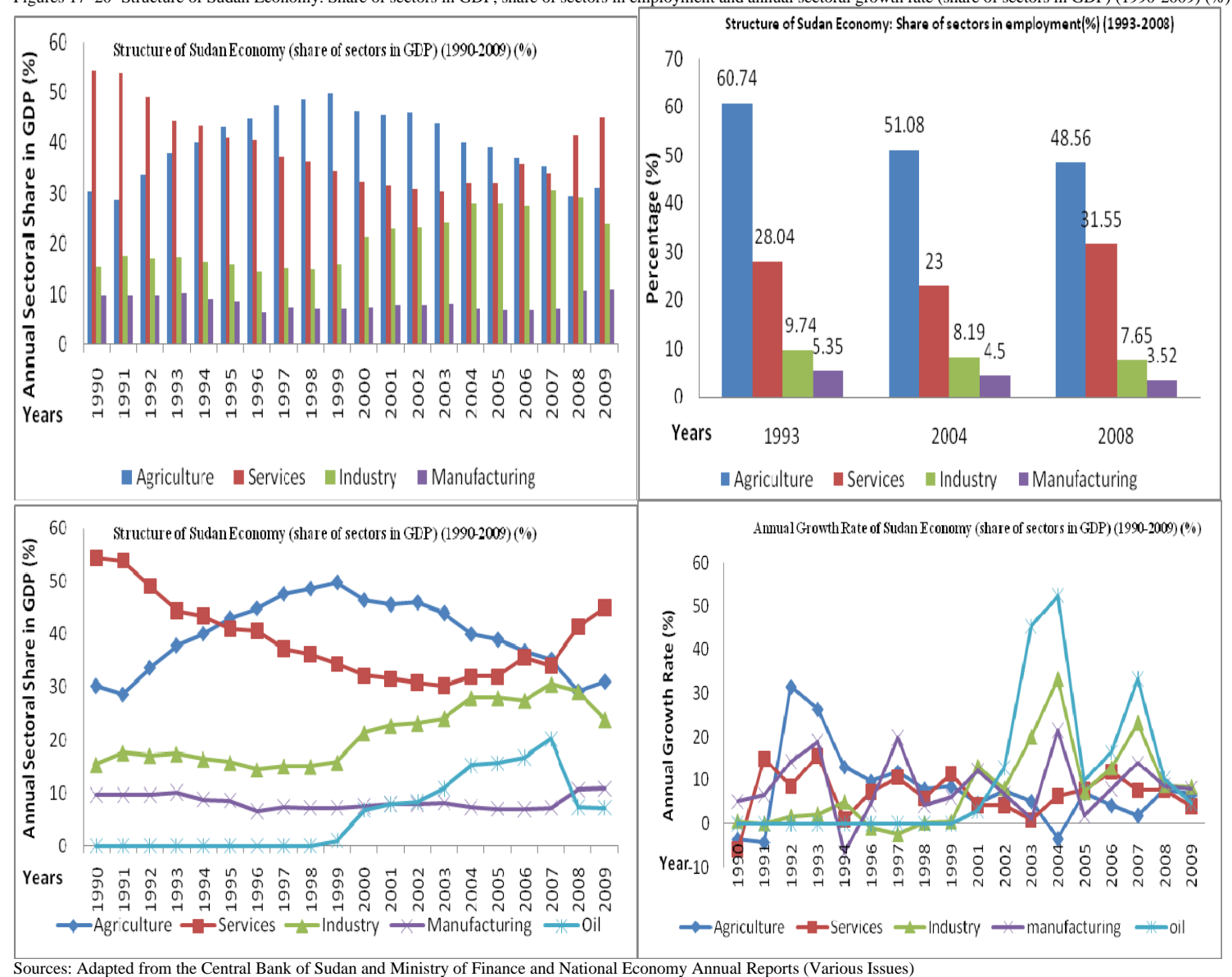

\footnotetext{
${ }^{70}$ See Bedawi, W. F. (2007) “A Brief Look At Sudan’s Major Economic Trends and Development Challenges,” Paper presented at the Ministry of Finance and National Economy and the World Bank "Macroeconomic and Fiscal Federalism Workshop" 14 - 31 July, 2007, Khartoum, Sudan.

${ }^{71}$ See Bedawi, W. F. (2007) “A Brief Look At Sudan’s Major Economic Trends and Development Challenges,” Paper presented at the Ministry of Finance and National Economy and the World Bank "Macroeconomic and Fiscal Federalism Workshop" 14 - 31 July, 2007, Khartoum, Sudan.
} 
Further challenge related to dependence on oil is the uncertainty in economic growth as measured by GDP and GDP Per capita growth rates over the long run that can be examined by comparing the current and future economic growth in Sudan compared with the rest of the region of North Africa. For instance, Sudan's economy is currently growing faster than the rest of the region of North Africa and is likely to continue to do so, but not for too long. By 2030, either oil prices will drop or Sudan's oil reserves will run dry leaving Sudan in the dust economically in comparison to the rest of North Africa. Economists predict that growth will persist for North Africa in the second half of the 21st century. Sudan's GDP will increase slowly throughout the century but will fall far below the measures of GDP for North Africa leaving Sudan with an extremely weak economy and a large disparity amongst it and its' geographic region. By the year 2050, Sudan's services sector will contribute to approximately 55\% of the economy. Energy and agriculture will decrease drastically. In contrast, materials and manufactures are predicted to increase slowly from 2000 to 2050. Looking at the bigger picture we notice that in North Africa we see that their services sector will likely increase from 35.5 (2000) to 55\% (2050). Their agricultural dimension is thought to decrease as well, plummeting from about $20 \%$ down to about $2 \%$. North Africa will probably see increases in manufactures, and decreases in energy, just as is predicted for Sudan. From the data, it seems as though Sudan is following the trend set forth by North Africa, but although many of the specific sectors that fluctuate are the same, the percentages of change vary greatly. Looking at Figure 21 below, we notice predictions of rapid growth within Sudan and North Africa. Increased GDP may be the cause for and/or caused by consumerism which leads to a greater demand for goods and services, thereby increasing the services sector of the economy and decreasing other measures. By 2050, Sudan seems to be struggling to keep up with the rest of the region. Perhaps the services they are providing are no longer affordable for as many people or maybe the loss of agricultural revenues due to an increase in Sudan's production sector can account for the lag in GDP. The demand for agriculture may still exist, forcing Sudan to spend funds on importing agricultural goods, depleting the amount of funding that circulates back through their economy leaving them in a struggle to keep up with the rest of North Africa. ${ }^{72}$ This implies that Sudan must implement strategy to avoid the negative consequences of declining growth rates in GDP and GDP per capita and uncertainty related to drop in oil reserves by using its oil production, which has helped to achieve impressive growth of its economy in the past decade, to create more balanced and sustainable growth over the long run and developing the industrial and agriculture sectors as the next possible alternative sources of growth to the oil sector in the medium-term.

\footnotetext{
${ }^{72}$ See "Production by Sector and its Influence on Economy: A comparative look at Sudan and North Africa"- Part IV: Economic Changes: What is the current State of Economy in Sudan?: http://www.faculty.fairfield.edu/faculty/hodgson/Courses/so191/Projects2007/Mannix/economicchanges.html, accessed 30 Oct 2010.
} 


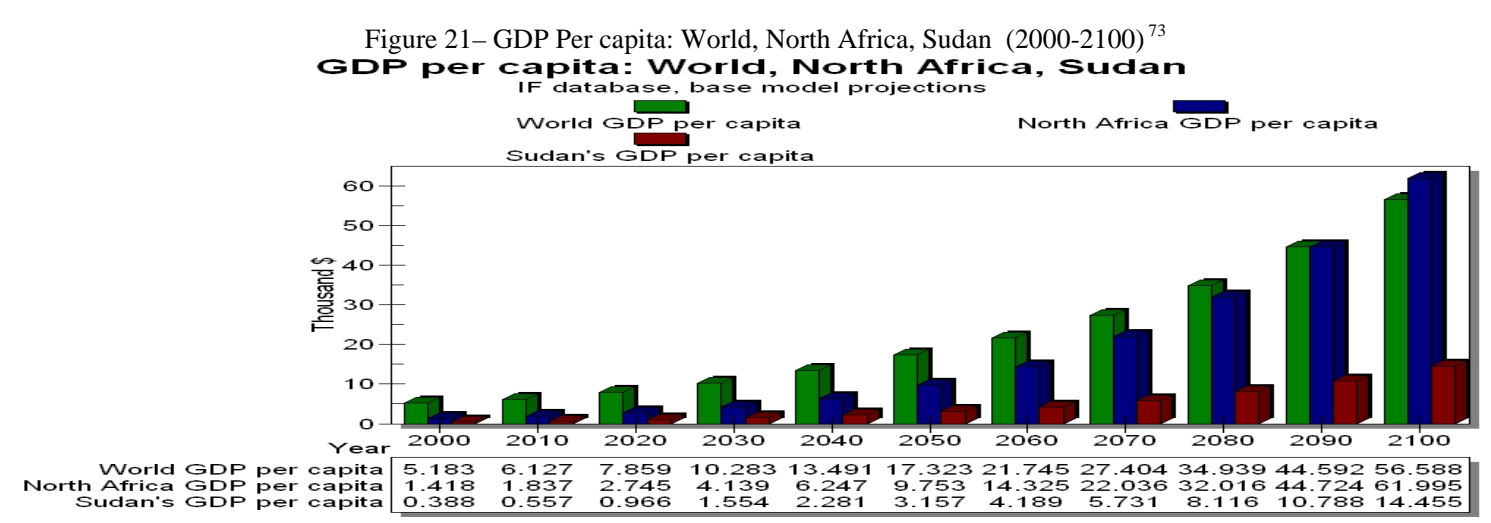

Another challenge related to oil is that oil revenues creates other internal problem by increasing the tension of continuous internal conflict related to the desire to maintain control over oil resources and failure to achieve an equitable distribution of oil revenues. ${ }^{74}$ For instance, in the past the exploration and production of oil is affected by the continuous conflict which involves the war and conflict over controlling oil resources. The exploration and production of Sudan's oil have been highly controversial issue... In January 2005 the CPA indicates several important issues, which included the sharing of oil revenues (50:50). ${ }^{75}$ In the recent year while oil-led growth over the past 10 years has greatly improved the Sudanese economy, its sustainability is under threat. From political perspective, at present time Sudan's rapid economic development has also created tensions that threaten to spark instability. From political perspective in the short run with the implementation of the CPA which implies the self-determination and a referendum in Southern Sudan to decide on unity or secession (that was just held in January 2011 in Southern Sudan), there is increasing tension on potential conflict between the north and south. This increasing tension is attributed to the fact that the two sides haven't reached an agreement on how to divide the revenues after the referendum. Under this situation and since the south is the source of most of the country's oil, the government in the north needs to invest in agriculture and other non-oil industries. According to the Sudan Minster of Finance as about 70 percent of Sudan's crude is pumped in the semi-autonomous region of Southern Sudan, so if Southern Sudan secedes, it could affect the economy negatively unless the northern and southern governments take measures to counter, since the north will loss most of the oil reserves (70\%) and oil revenues (50\%) and the south will remain dependent on the main pipeline passing through the north. ${ }^{76}$ Sudan's northern and southern regions now split the proceeds from oil

\footnotetext{
${ }^{73}$ See "Production by Sector and its Influence on Economy: A comparative look at Sudan and North Africa"

"Part IV: Economic Changes: What is the current State of Economy in Sudan?: http://www.faculty.fairfield.edu/faculty/hodgson/Courses/so191/Projects2007/Mannix/economicchanges.html

74 "Oil has always an issue in the Sudanese conflict. For instance, the organized non-government political activity resisting oil extraction: On 30 August 1999, Sudan's pipeline with a capacity for 100,000 barrels/day filled the first tanker at the supertanker port on the Red Sea. Not one month later, on 20 September, anti-government forces exploded a portion of the pipeline outside the town of Atbara. Moreover, due to conflict, oil exploration has been mostly limited to the central and south-central regions of the country". (See Sudan Factsheet Human Rights and Oil workshop-January 31, 2003, pp. 1-2 see also Sudan Fact oil fact sheet, 2006, pp. 1-2)

${ }^{75}$ See for instance, Oil fact sheet on Sudan, September 2006 Produced by C. Pinaud for UnderstandingSudan.org, 2006 , p. 2.

${ }^{76}$ See Asharq Al-Awsat Newspaper (2010) "Asharq Al-Awsat Interview with Sudan's Finance Minister Ali Mahmoud" Saturday October 16, 2010, Issue No 11645: http://www.aawsat.com/details.asp?section=4\&issueno=11645\&article=591143\&state=true.
} 
pumped in the south. If the country is divided and the south is seceded, the north will remain the south's only export route through a pipeline ending in the seaport in Port Sudan at the Red Sea in the north. This implies that oil remains a controversy issue in the north-south conflict not only in the past, but also in the future, as it also creates challenges of potential future north-south conflict.

Oil also has affected the labor market because the exploration and production of oil leads to creation of more employment opportunities -although difficult to elaborate due to lack of accurate data. But on the other hand the inflow of FDI and the increased wealth from oil has encouraged migration to the Sudan. Consequently, migrant workers have increased in the labour market, particularly in the private sector, which may also contribute to the growing unemployment rate. Furthermore, oil also affected the structure of wages and lead to wage differential in Sudan, for instance, the results of the comprehensive industrial survey (2005), indicates that the highest compensation for workers in the industrial sector is reported in the petroleum refining industry which is 18 times more than the average compensation in the industry. ${ }^{77}$

\section{Conclusions}

This paper explains the the general political context, socioeconomic characteristics of Sudan, and strategic problems for development in the Sudan, explains the role of oil in the Sudan, discusses the strategic problems facing the labour market in the Sudan and highlights the need for skill upgrading and technological development.

We begin by explaining the general socio-economic characteristics of Sudan economy; we then provide a historical background about the structure, investment, exploration and production of oil in Sudan and explain the role of China in investment in oil sector in Sudan. We explain the various positive impacts of oil and the opportunities for development in Sudan economy; this includes the impacts of oil in satisfying domestic consumption and achievement of self sufficiency, the impact of oil in increasing government resources as measured by the share of Sudan government in oil revenues from partnership with foreign oil producing companies in Sudan. In addition to the impacts of oil on Sudan's economic growth as measured by the growth in the GDP and its composition or structure, the impacts of oil on the public government budget as measured by the government revenues and government spending. In addition to the impacts of oil on foreign trade as measured by the volume and structure of exports, the impacts of oil in the balance of trade and balance of payment. In addition to the impact of oil on foreign direct investment (FDI) and finally the impacts of oil in improving Sudan's relationship with external regional and international financial institutions. After explaining the positive impacts of oil and the opportunities for development in the Sudan we show the negative impacts of oil and the 
challenges of development in Sudan. These include the high volatility and risk of dependence on highly fluctuating oil prices in the international market, un-sustained oil revenues, the lack of diversification, Dutch disease and the challenges of potential north-south conflict.

\section{References}

Ali Abdalla Ali(2007)“EU,ChinaandAfrica;TheSudaneseExperience” Sudantribune, Tuesday 10 July 2007 03:30:: http://www.sudantribune.com/spip.php?article22783.

Asharq Al-Awsat Newspaper (2010) "Asharq Al-Awsat Interview with Sudan's Finance Minister Ali Mahmoud" $\begin{array}{llllll}\text { Saturday } & \text { October } & 16, & 2010, & \text { Issue } & \text { No }\end{array}$ http://www.aawsat.com/details.asp? section=4\&issueno=11645\&article=591143\&state=true.

Bedawi, W. F. (2007) “A Brief Look At Sudan’s Major Economic Trends and Development Challenges,” Paper presented at the Ministry of Finance and National Economy and the World Bank "Macroeconomic and Fiscal Federalism Workshop” 14 - 31 July, 2007, Khartoum, Sudan.

Corden, W.M. (1984) “Booming Sector and Dutch Disease Economics: Survey and Consolidation,” Oxford Economic Papers 36 (November 1984): 360-62.

Elbadawi, I. A. and Kaltani L. (2007) “The Macroeconomics of Oil Booms: Lessons for SSA,” Development Economics Research Group, Economists’ Forum, April 19, 2007. Paper presented at the Ministry of Finance and National Economy and the World Bank "Macroeconomic and Fiscal Federalism Workshop" 14 - 31 July, 2007, Khartoum, Sudan.

Ilaf Newspaper (2009) "How Oil affected the composition and structure of Sudan Economy? And what are the Consequences,” fifth year, Issue No. 239 Wednesday September 9, 2009, (in Arabic) p.5. Khartoum, Sudan.

IMF International Monetary Fund, World Economic Outlook Database, April 2009, www.imf.org

IMF Report on the implications of the Global Financial Crisis for Low-Income Countries, March 2009, p.48: http://www.imf.org/external/pubs/ft/books/2009/globalfin/globalfin.pdf

IMF projection for 2008

IMF First Review of Performance Under the 2007-08 Staff-Monitored Program, June 2008, p.2

IMF Report on the implications of the Global Financial Crisis for Low-Income Countries, March 2009, p.50

International Energy Agency Estimates; International Energy Annual, IPM_www.eia.doe.gov/cabs/Sudan/Oil.html

International Labor Organization (2007)

Nour, S. (2009), "The Impact of China-Africa Aid Relations: the case of Sudan" Unpublished report for the African Economic Research Consortium (AERC) Collaborative Research Project on The Impact of China-Africa Economic Relations, January- August 2009.

Palma, G. (2003) “Four Sources of de-industrialisation and a new concept of the Dutch Disease,” Unpublished paper presented at UNU- INTECH Research Seminar Series 2004-2, 19 May 2004: p. 21

Salih, S. H. (2004) "Sudanese Oil: The Story of the Struggle of a nation," Sudan Currency Printing Press Company Ltd., Khartoum, Sudan, 2004, (in Arabic) pp. 21-40, 166, 93-94, 91, 182.

Sudan Central Bureau of Statistics- Department of Internal Commerce and Pricing.

Sudan Central Bureau of Statistics Population Census Data (2010): 5th Sudan Population and Housing Census (2008)

Sudan Central Bureau of Statistics (2008) "Sudan statistical year book: Sudan statistics 2008,” Sudan Central Bureau of Statistics, Sudan Ministry of the Cabinet..

Sudan Central Bureau of Statistics (2008) "Sudan statistical year book: Sudan statistics 1990- 2008,” Sudan Central Bureau of Statistics, Sudan Ministry of the Cabinet: pp. 3, 39-43.

Sudan Central Bureau of Statistics Statistical Year Book (2008), "Sudan Economy in Figures: General Information” pp. XI-XII.

Sudan Central Bureau of Statistics (2007) “Sudan statistical year book: Sudan statistics 2007,” Sudan Central Bureau of Statistics, Sudan Ministry of the Cabinet.

Sudan Central Bureau of Statistics: Volume 2, Economic and Social Characteristics.

Sudan Factsheet Human Rights \& Oil workshop - January 31, 2003, pp 1-2.

Sudan Health and Household Survey 2006

Sudan Oil fact sheet on Sudan, September 2006, produced by C. Pinaud for UnderstandingSudan.org, 2006, pp.1-2

Sudan Ministry of Finance and National Economy- Annual Economic Survey Report (Various Issues: 1997-2007)

Sudan Ministry of Finance and National Economy (2008) Unpublished Report (2008),

Sudan Ministry of Finance and National Economy (2006) “The Performance of Sudan Economy 2000-2005” April, 2006, pp: 16-18

Sudan Ministry of Finance and National Economy (2005) "the Sudan Economy in Figure: 2000-2005" (Second edition), Ministry of Finance and National Economy, Macroeconomic Policies and Programme Directorate MEPPD, Khartoum, Sudan, (2005).

Sudan Ministry of Finance and National Economy (2002) "the Sudan Economy in Figure: 1990-2002" (First edition), Ministry of Finance and National Economy, Macroeconomic Policies and Programme Directorate MEPPD, Khartoum, Sudan, (2002), p 27.

Sudan Ministry of Finance and National Economy- Annual Economic Survey 2000, Table 7-2, p. 10.

\footnotetext{
${ }^{77}$ See the Executive Summary of the Sudan Comprehensive Industrial Survey, (2005), p. 29.
} 
Sudan Ministry of Energy and Mining (2008) “Unpublished Report” (2008), Khartoum, Sudan.

Sudan Ministry of Foreign Trade and Central Bank of Sudan Annual Foreign Trade Statistical Digest various issues (1997-2010): 2006: p. 20, p. 38. 2005: p. 38, p.20. 2004: p. 20, p. 39. 2002: p. 9, p. 24. 2000: p. 9, p. 24. 1998: pp. 12-13, pp. 33-34. 1997: pp. 12-13, pp. 33-34, 2010.

Sudan Ministry of Industry (2005) “The Comprehensive Industrial Survey (2005)”, Khartoum, Sudan, July, 2005: The executive summary of the comprehensive industrial survey, (2005), p. 29.

Sudan Ministry of International Cooperation.

Sudan Ministry of Investment unpublished statistics and data from the feasibility studies (2009)

The United Nations Development Programme UNDP- The Arab Human Development Report (2003): Arab human development report 2003: Building a knowledge society. Amman, Jordan: UNDP-RBAS; New York, NY: National Press.Table 5.1 p.102.

The Central Bank of Sudan Annual Report (Various Issues: 1999-2009)

The Central Bank of Sudan Annual Report (2009), p. 84.

The Central Bank of Sudan Annual Report (2004), p. 36.

The Central Bank of Sudan $44^{\text {th }}$ Annual Report (2004): Appendix No. XVI, pp. 188-189; and $48^{\text {th }}$ Annual Report (2008): Appendix No XVI-B-XVII-B, pp.158-164).

The United Nations Development Programme UNDP (2010): UNDP Sudan Country profile of Human Development Indicators (2010): http://hdrstats.undp.org/en/countries/profiles/SDN.html, accessed on December 22, 2010.

The United Nations Development Programme UNDP (2009) "Human development report 2009: Overcoming barriers: Human mobility and development. New York, NY: UNDP."

The United Nations Development Programme UNDP- HDR (2007/2008) "Human development report 2007/2008: Fighting climate change: Human solidarity in a divided world”. New York, NY: UNDP pp. 231-232, 392293.

The United Nations Millennium Development Goals in Sudan "Sudan Millennium Development Goals Interim Unified Report, 2004”: http://www.sd.undp.org/mdg_sudan.htm, accessed on June 01

The United Nations Development Programme UNDP in Sudan (2006) "Macroeconomic Policies for Poverty Poverty Reduction: The Case of Sudan," Khartoum, Sudan, 2006.

The United Nations Development Programme UNDP (2006): "employment generation and poverty reduction," Chapter Nine in the 2006 UNDP report on "Macroeconomic Policies for Poverty Reduction: the case of Sudan” published for the UNDP in Sudan, Khartoum, Sudan, June 1006 pp. 92-94.

The UN Resident Coordinator's Support Office, Khartoum, Sudan: http://www.sd.undp.org/mdg_fact.htm, accessed in June 01, 2010.

The World Bank (WB-DTS) (2008) “Revitalizing Sudan’s Non-Oil Exports: A Diagnostic Trade Integration Study (DTIS) Prepared for the Integrated Framework Program (December 2008)” A Revised version of "Sudan Diagnostic Trade Integration Study (DTS), Poverty Reduction and Economic Management 2- Africa region,, Draft: may 2, 2008, Decision Meeting: May 13, 2008”: pp. viii-ix; 1-7: http://www.integratedframework.org/files/english/Sudan\%20DTIS\%20final.pdf

The World Bank, (2003), Vol. 1: 44.

The World Bank Sudan Economic Brief April 2009.

The World Development Indicators (WDI)/ IMF/World Bank Staff Estimate (2008)

The World Development Indicator database: WDI (2005).

The World Investment Report (2002) UNCTAD.

US Library of Congress Country Studies (1991) "Sudan - Foreign Aid" Data as of June 199:1 http://www.photius.com/countries/sudan/economy/sudan_economy_foreign_aid.html: accessed February 03, 2009.

Production by Sector and its Influence on Economy: A comparative look at Sudan and North Africa”-Part IV: Economic Changes: What is the current State of Economy in Sudan?: http://www.faculty.fairfield.edu/faculty/hodgson/Courses/so191/Projects2007/Mannix/economicchanges.ht $\mathrm{ml}$

Wikipedia: http://en.wikipedia.org/wiki/Brain_drain, accessed November 14, 2010.

Wikipedia: http://en.wikipedia.org/wiki/Second_Sudanese_Civil_War: Accessed in November 10, 2010.

Wikipedia: http://en.wikipedia.org/wiki/Sudan Accessed June 01 ${ }^{\text {st }}, 2010$ 


\section{The UNU-MERIT WORKING Paper Series}

2011-01 Mitigating 'anticommons' harms to research in science and technology by Paul A. David

2011-02 Telemedicine and primary health: the virtual doctor project Zambia by Evans Mupela, Paul Mustard and Huw Jones

2011-03 Russia's emerging multinational companies amidst the global economic crisis by Sergey Filippov

2011-04 Assessment of Gender Gap in Sudan by Samia Satti Osman Mohamed Nour

2011-05 Assessment of Effectiveness of China Aid in Financing Development in Sudan by Samia Satti Osman Mohamed Nour

2011-06 Assessment of the Impacts of Oil: Opportunities and Challenges for Economic Development in Sudan by Samia Satti Osman Mohamed Nour 